\title{
La Orden de San Juan de Dios entre epidemias y pandemias: 500 años de servicio socio-sanitario a la población más vulnerable
}

\author{
The Order of St. John of God among epidemics \\ and pandemics: 500 years of socio-health \\ service to the most vulnerable population
}

\author{
Francisco Benavides Vázquez \\ Director del Archivo-Museo San Juan de Dios "Casa de los Pisa" \\ Orden Hospitalaria.Granada \\ https://orcid.org/0000-0001-7091-0251
}

\begin{abstract}
Resumen: A lo largo de la historia de la Orden Hospitalaria son muchas las epidemias y pandemias que le ha tocado afrontar con creatividad, entrega y excelencia. En este estudio se realiza un análisis histórico de las diferentes epidemias afrontadas por los Hermanos de San Juan de Dios desde 1580 con la epidemia de "catarro, la llegada de la peste en el siglo XVII, el tifus, la cooperación entre del Hermano Chaparro y el Dr. Balmis contra la viruela, la fiebre amarilla, el cólera y la heroica actuación de los Hermanos liderada por Benito Menni O.H. en la campaña anticolérica a finales del siglo XIX; hasta la propagación de epidemias más recientes como el VIH en la década de los ochenta, la repercusión social con el Ébola en el 2014 y el fallecimiento de numerosos Hermanos y colaboradores en los centros hospitalarios de África, y finalmente, la actual Covid-19 que amenaza nuestra sociedad.
\end{abstract}

En este artículo, se refleja como los Hermanos y colaboradores se han volcado en el cuidado de los más vulnerables y en la lucha contra las diversas enfermedades que han asolado a millones de poblaciones durante casi 500 años, siguiendo el ejemplo de san Juan de Dios.

En cada una de estas pandemias, la Orden Hospitalaria con determinación y humanización ha sabido afrontar y aplica los principios más fundamentales de la institución en cada uno de los delicados momentos socio-sanitarios que en este estudio se muestran.

Palabras claves: Asistencia socio-sanitaria, Cólera; Covid-19; Ébola; Epidemia; Fiebre amarilla; Hermanos de San Juan de Dios; Hospitalidad; Orden Hospitalaria; Peste; Tifus; Viruela; VIH.

Abstract: Throughout the history of the Hospitaller Order, there are many epidemics and pandemics that it has had to face with creativity, dedication and excellence. This study presents a historical 
analysis of the different epidemics faced by the Brothers of Saint John of God since 1580 with the epidemic of "catarro", the arrival of plague in the seventeenth century, typhus, cooperation between $\mathrm{Br}$. Chaparro and Dr. Balmis against smallpox, yellow fever, cholera and the heroic performance of the Brothers led by Br. Benito Menni in the anticholeric campaign at the end of the nineteenth century; until the spread of more recent epidemics such as HIV in the 1980s, the social impact of Ebola in 2014 and the deaths of numerous Brothers and collaborators in hospitals in Africa, and finally, the current Covid-19 that threatens our society.

In this article, it is reflected how the Brothers and collaborators have focused on the care of the most vulnerable and in the fight against the various diseases that have ravaged millions of populations for almost 500 years, following the example of St. John of God.

In each of these pandemics, the Hospitaller Order with determination and humanization has been able to face and apply the most fundamental principles of the institution in each of the delicate socio-health moments shown in this study.

Keywords: Brothers of Saint John of God; Cholera; Covid-19; Ebola; Epidemic; HIV; Hospitality; Hospitaller Order; Plague; Smallpox; Socio-health service; Typhus; Yellow fever.

\section{INTRODUCCIÓN}

Veíamos las epidemias y pandemias como algo alejado, algo que había tenido lugar en otro tiempo donde la ciencia no había avanzado lo suficiente, donde la insalubridad y la falta de medidas higiénicas era una constante. Hoy hemos vuelto a revivir en primera persona todo aquello que sabíamos por la historia. Somos actores principales de un acontecimiento histórico y aún no hemos tomado conciencia de la dimensión de esta realidad, ni las consecuencias futuras que podrá alcanzar.

En otro tiempo, instituciones de la iglesia siempre dieron un paso adelante para salir al encuentro de la persona que sufría la enfermedad. Todo un sustrato cristiano hay en esta dinámica de cuidado y curación. La Orden Hospitalaria de San Juan de Dios se encuentra entre una de las instituciones cristianas que desde su origen nació con la finalidad de compartir con el otro sus desdichas, su vulnerabilidad, en definitiva, sus necesidades. Juan Ciudad es el fundador e impulsor de un nuevo movimiento en favor de la persona. Su actitud frente al individuo, especialmente la que sufre, supuso toda una novedad en la mentalidad del siglo XVI. El modelo creado por él sigue siendo de plena actualidad y sigue sosteniendo a una institución que ha prestado su servicio en tiempos de enfermedades y calamidades 
ejemplarmente. Dando incluso la vida muchos de sus miembros en el ejercicio de la hospitalidad.

La Orden de San Juan de Dios es una institución que ha resistido el paso del tiempo. Es testigo activo de un proceso constante de enfermedad y necesidad por el que ha pasado la sociedad a lo largo de casi quinientos años. Frente a la enfermedad (epidemias y pandemias) se ha situación siempre de modo generoso y creativo. Un largo recorrido podemos documentar a lo largo de esta historia de siglos. Este es el propósito de este

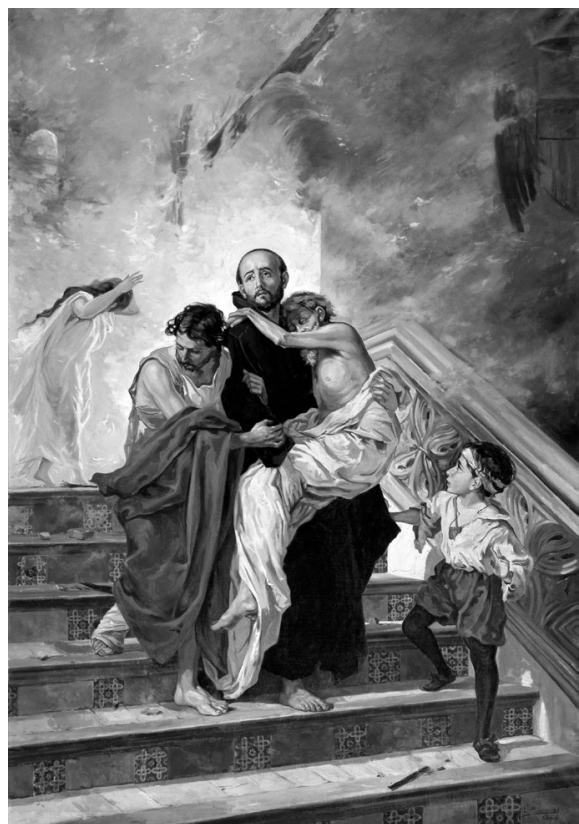
trabajo. Ordenar de modo coherente y riguroso un relato que ha ido construyendo la Familia de San Juan de Dios. Siempre fundamentado en una vida ejemplar, en una actitud permanente de servicio ejercido por Juan Ciudad, San Juan de Dios ${ }^{1}$, desde una dimensión humana y trascendente.

Entre dos ideas podemos ubicar todo este recorrido:

1.- "Las epidemias no son algo nuevo para la humanidad, solo son nuevas para nosotros" [Nicholas Christakis²]. La enfermedad es una constante, consustancial a la persona. Que nos acecha y persigue a lo largo de nuestra biografía.

2.- "Por el voto de hospitalidad nos dedicamos, a la asistencia de los enfermos y necesitados comprometiéndonos a prestarles todos los servicios necesarios, por humildes que sean, incluso con peligro de la propia vida, a imitación de Jesucristo, que nos amó hasta morir por nuestra salvación" [Constituciones O.H. $\mathrm{n}^{\circ}$

1 JAVIERRE, José María. Juan de Dios loco en Granada. Salamanca: Ediciones Sígueme, 1996.

2 CHRISTAKIS Nicholas. Apollo'sArrow: Theprofund and enduringimpact of coronavirus onthewaywelive. EE.UU: Universidad de Yale, 2021. 
$\left.22^{3}\right]$. La respuesta radical que ejerce un colectivo profundamente motivado por sus valores identitarios frente a esta realidad. Incluso arriesgando la propia vida. En muchos casos dándola generosamente.

A lo largo de la historia la Orden Hospitalaria no se ha caracterizado precisamente por documentar sus actuaciones, ni siquiera aquellas más heroicas. No obstante hemos recurrido a todos aquellas fuentes documentales, dispersas, que pueden arrojar luz sobre la cuestión que aquí abordamos. Así, hemos querido aprovechar esta oportunidad para recopilar y ofrecer en este texto fuentes documentales escritas y gráficas sobre las epidemias y pandemias más recientes, como el Ébola y la Covid-19. Con el propósito de que en un futuro puedan estar más accesible y ser más conocida.

\section{SAN JUAN DE DIOS $Y$ SU NUEVA MANERA DE CUIDAR}

La Orden Hospitalaria hunde sus raíces y se sustenta en un modelo concreto de cuidados basado fundamentalmente en la convicción del servicio al otro, al prójimo. Su fundador carismático e inspirador es Juan Ciudad Duarte, un ciudadano que vive en la primera mitad del siglo XVI en España. Su experiencia vital es muy amplia y nos resulta bastante difícil resumir. Pero en dos expresiones se vertebra su existencia: búsqueda y servicio.

Búsqueda de la voluntad de Dios sobre su persona y servicio generoso y desinteresado hacia los demás. Quizá en una de las cartas ${ }^{4}$ que dirigiera a la Duquesa de Sessa (una de sus más destacadas bienhechoras) resuma estos dos aspectos: "si supierais lo grande que es la Misericordia de Dios, no dejaríais de hacer el bien mientras pudieseis". Su experiencia trascendental le lleva a darse en "cuerpo y alma" a los demás.

Tras un dilatado recorrido de búsqueda, a través de las diferentes experiencias por las que atravesó su vida, recala en Granada en torno a 1538 vendiendo libros. Había salido muy pequeño del hogar

3 RIESCO ÁLVAREZ, Valentín A. O.H. Seguir y servir a Cristo en Hospitalidad. Constituciones de la Orden Hospitalaria de San Juan de Dios. Madrid: Fundación San Juan de Dios, 2019.

4 GARCÍA BLANCO, Miguel, O.H. Cartas de San Juan de Dios. Texto original y transcripción moderna. Roma, 1987. 
familiar, había trabajado en el campo como pastor, como soldado y albañil, en una continua búsqueda de la voluntad de Dios. Es finalmente Granada la ciudad que lo ve hacerse santo tras un encuentro providencial con el maestro Juan de Ávila, hoy también San Juan de Ávila ${ }^{5}$. Su experiencia de conversión lo lleva a entregarse a los demás, hasta dar su propia vida.

Juan de Dios vivió en perfecta unidad el amor a Dios y al prójimo. Se dedicó por entero al servicio de sus hermanos e imitó fielmente a Jesús en sus actitudes y gestos de caridad y misericordia. Lleno de trabajos, preocupaciones y deudas, confió solo en la trascendencia y se entregó por completo al servicio de los pobres y enfermos de Granada y fuera de ella.

Su sentido de evangelización, más que caracterizarse por claves de sacramentalización y moralización, se basó en la encarnación de actitudes y valores cristianos, en el servicio a la persona.

Su objetivo era que el hombre y la mujer fueran más humanos, tratados con más dignidad, y que las relaciones con ellos fueran más humanas. Su trabajo consistió en un servicio a la persona, en su contexto histórico.

Juan de Dios, testigo de una sociedad y un ambiente concreto, agraciado por la llamada de Dios, lleva en sí y en sus manifestaciones, influencias múltiples. Pero sobre todo, lleva del Jesús buen samaritano, su silueta y ejemplos para encarnarlos entre los hombres y mujeres necesitados de una acción desde la caridad y la misericordia. Esta realidad se convierte en obsesión vital y creadora. Se consagra a ella con toda la fuerza de su alma.

Cuando descubre que lo decisivo en la vida acontece entre el yo y el tú y lo asume, su compasión y su preferencia por rehacer la vida de los demás desde ellos mismos, sin juzgarlos ni reprochar nada, comienza a dar y darse con espontaneidad y desinterés. ${ }^{6}$

Ya en vida, su manera de ser y hacer genera un movimiento integrado por seguidores "consagrados" y colaboradores que tras su

5 MUÑOZ DEVESA, Aarón. Una visión de los cuidados espirituales de San Juan de Dios, influidos por San Juan de Ávila, desde las taxonomías enfermeras actuales. Murcia: Universidad Católica, 2017 (Tesis doctoral inédita)

6 VENTOSA ESQUINALDO. Francisco, O.H. Pensamiento de San Juan de Dios y la Orden Hospitalaria y su relación con la enfermería: conceptos y valores. Granada: Archivo - Museo San Juan de Dios "Casa de los Pisa", 2012. Colección Temas Históricos O.H. 
muerte, que acontece en Granada en 1550, heredan un estilo de hacer las cosas. Una cultura de cuidados basada en el amor y el respeto al prójimo. De modo especial al más vulnerable y desprotegido. En 1571 el papa Pio V reconoce a ese grupo con la Bula Licet ex debito. Con muchas limitaciones, precariedades y esfuerzos la Orden Hospitalaria comienza su consolidación y expansión. Con no pocas dificultades, aciertos y errores ha llegado a nuestros días. Así suma casi 500 años de experiencia y servicio una institución de iglesia que ha caminado integrada, como no puede ser de otra manera, con la sociedad de su tiempo. Compartiendo épocas de bonanza y también épocas de epidemias y guerras. La Orden Hospitalaria es actor activo de la humanidad de su tiempo. Me atrevo a decir que con un papel destacado por su cercanía a la realidad de los hombres y mujeres de cada momento.

Con esta herencia de servicio y de cuidado al enfermo y necesitado, inspirada por la vida de San Juan de Dios, la Orden ha estado presente siempre en las diferentes epidemias por las que ha atravesado nuestra sociedad. En este estudio nos vamos a circunscribir únicamente al caso de España. Por no alargarnos en demasía saliendo de estas fronteras.

\section{LA HOSPITALIDAD DE JUAN DE DIOS: UN MODELO INSPIRADOR}

El carisma de la hospitalidad significa un don concedido por el Espíritu para una misión eclesial a favor de los pobres y necesitados. San Juan de Dios, nuestro fundador vivió este carisma y su consiguiente misión con un estilo propio y tan característico que inició una "cultura" hospitalaria original y de gran vitalidad. La "cultura" hospitalaria de Juan de Dios constituye un valor original profético de renovación en la Iglesia y en la sociedad.

\section{A. Hospitalidad misericordiosa}

La hospitalidad juandediana ha brotado de la experiencia cristiana de la misericordia de Dios hacia nuestro Fundador que le ha revelado su condición de pecador y la gran misericordia y amor de Dios que perdona gratuitamente y quiere la comunión de vida con todos sus hijos. Esta experiencia constituye la característica fundamental y la fuente de la que brota la riqueza de la hospitalidad de San Juan de Dios: “Si 
considerásemos lo grande que es la misericordia de Dios, nunca dejaríamos de hacer el bien mientras pudiésemos" ${ }^{7}$.

Solemos considerar a San Juan de Dios como fundamentalmente misericordioso, compasivo, capaz de entender, perdonar y ayudar; y lo hacemos con razón, pero esto no es más que la consecuencia de su conciencia y de su vivencia permanente de la misericordia y del perdón de Dios y de Cristo para con él. Él veía la vida y las cosas de la vida como dones divinos

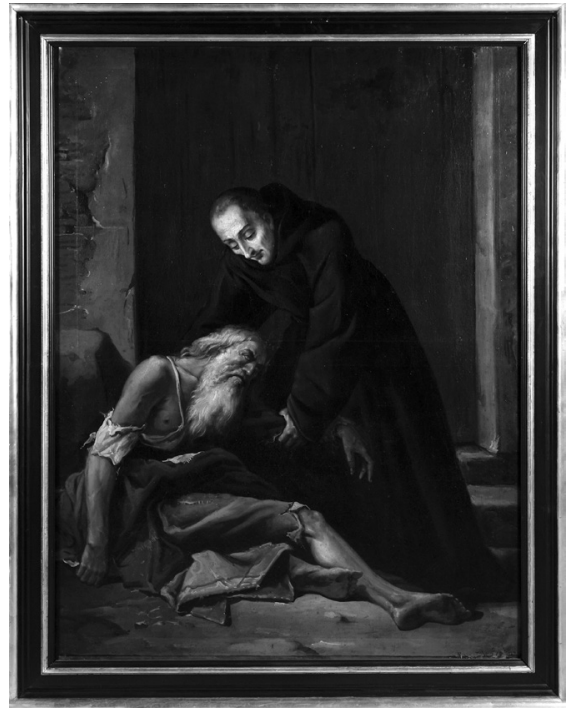
gratuitos de la misericordia divina:"Jesucristo usa con nosotros de tanta misericordia, dándonos la comida, la bebida, el vestido y todas las cosas, sin merecerlo".

El bien más deseado y pedido por nuestro fundador durante su conversión ha sido el perdón y la misericordia divina tal y como lo podemos leer en los capítulos VII, VIII y IX de Castro ${ }^{8}$. Ha suspirado y ha pedido misericordia al Señor $y$, al recibirla, se ha convertido en su intermediario para con todos los necesitados.

La hospitalidad misericordiosa de San Juan de Dios es, sin duda, lo que más llama la atención, por sus acciones extraordinarias a favor de todas las categorías de necesitados y sufrientes.

Podemos afirmar de manera absoluta que la experiencia profunda de la hospitalidad misericordiosa de Dios hacia él lo ha transformado en hospitalario misericordioso hacia todos sin excepción y casi, podemos decir, sin límites. En sus acciones no conocemos límite de necesitados y sufrientes que no haya socorrido. La lista de los necesitados de Granada y de los alrededores socorridos por San Juan de Dios que Castro nos presenta en el capítulo XII y la que el mismo Santo presenta en la segunda carta a Gutiérrez

7 CASTRO, Francisco de. Historia de la vida y sanctas obras de Juan de Dios... Granada: Antonio de Librixa, 1585.

8 CASTRO, Francisco de. Historia de la vida y sanctas obras de Juan de Dios... Granada: Antonio de Librixa, 1585. 
Lasso coinciden y cubren casi todas las categorías existentes en la Granada de su tiempo.

\section{B. Hospitalidad solidaria}

Esta experiencia y revelación de la misericordia de Dios hacia él provocó dos respuestas: una de kénosis o humillación penitencial bien visible en las fuentes, y luego una respuesta de servicio de hospitalidad misericordiosa hacia todos los necesitados, sufrientes y pecadores. Francisco de Castro nos describe cómo Juan de Dios, el día de su conversión, de pobre librero se deshizo de todo lo que tenía para ser un seguidor de Jesucristo. Dice, además:

"Andaba siempre descalzo en la ciudad y en todos los caminos, y descaperuzado, y rapado a navaja barba y cabeza, y sin camisa ni otro vestido más que un capote de xerga ceñido y unos zaragüelles de frisa; andaba siempre a pie, sin subir jamás en alguna bestia en camino ni fuera del, por cansado y despeado que viniese; ni por tempestades de agua y nieve que hubiese se cubrió la cabeza desde el día que comenzó a servir a nuestro Señor hasta que lo llamó para sí; y con todo eso se compadecía de los muy livianos trabajos de sus próximos, y los procuraba remediar, como si él viviera en mucho regalo".

\section{Hospitalidad de comunión}

Intermediario entre ricos y pobres, entre categorías de opulentos y necesitados, entre poderosos y despreciados, San Juan de Dios ha practicado la hospitalidad de comunión.

Con San Juan de Dios la colecta de limosnas se ha convertido en patrimonio y en una riqueza espiritual de la Orden de la que no se puede prescindir, pese a haber adaptado sus métodos a cada época y cultura. Es necesario considerarla como circulación de bienes para la construcción solidaria y espiritual de la sociedad.

Cuando gritaba de noche por las calles:"haced el bien hermanos a vosotros mismos por amor de Dios" quería inquietar y provocar las conciencias a no dormirse sobre las miserias de sus hermanos, pedía y daba en una reciprocidad dinámica. Invitaba a ejercer la comunicación cristiana de bienes.

Cuando escribía cartas agradeciendo los dones recibidos y contando su dolor por los sufrimientos de los miserables que no podía 




asistir solo y cuando pedía continuos préstamos que pagaba con dificultad, quería construir una comunidad de comunión en la que todos se sintieran hermanos, amados, ayudados y perdonados por Dios como se sentía él. Sabía qué si todos hubiesen tenido una experiencia profunda de la misericordia de Dios, como él la quería, la Iglesia y la sociedad se hubieran convertido realmente en la familia de los hijos de Dios habitados por la vida y la comunión divina superando las necesidades de los necesitados.

\section{Hospitalidad creativa}

En una ciudad con casi diez hospitales y casas para los pobres, es increíble cómo la sensibilidad de San Juan de Dios haya descubierto a tantos necesitados y enfermos abandonados.Y sorprende aún más cómo haya logrado abrirse un espacio nuevo en la manera de practicar la hospitalidad. Ha anticipado a los que tenían la responsabilidad de precederlo para resolver los problemas de los enfermos, de los pobres y de los necesitados.

Su hospitalidad era respuesta a los que no la encontraban (abandonados) y a las necesidades nuevas que no despertaban la sensibilidad de los demás (sufrientes a causa de culpabilidades, odio o venganzas). San Juan de Dios veía todo sufrimiento, del cuerpo y del espíritu. 


\section{E. Hospitalidad integral (holística)}

Podemos afirmar que uno de los valores característicos de la hospitalidad juandediana es la integralidad de los cuidados dirigidos a toda la persona que sufre. Para él el enfermo y el necesitado no era sólo un cuerpo y un alma, pecador o pecadora, un mentiroso o un indigno. Todas eran personas, hermanos y hermanas suyos, todos dignos de ser ayudados y perdonados por él y por sus Colaboradores. Y ¿por qué? Porque lo mismo hace Dios proveyendo cada día a las necesidades de todos, perdonando y salvando. Y porque el verlos sufrir le "partía el corazón".

La hospitalidad de San Juan de Dios, diríamos hoy, era al mismo tiempo preventiva y de emergencia, curativa y rehabilitadora, curaba los curables y acompañaba a los incurables. Era además pedagógica y formativa para los huérfanos, los niños expuestos y las prostitutas y para quienes ayudaba a liberarse de su culpa, a construir y llevar adelante un proyecto de formación y de inserción social. En su hospital ofrecía cama y comida, fuego y locales para acoger a los peregrinos; medicamentos, enfermeros, médicos, capellanes y ayudas espirituales para los enfermos.

\section{F. Hospitalidad reconciliante}

San Juan de Dios era comprensivo y trataba a todos, pecadores, opresores y oprimidos, como Dios le trataba a él: perdonaba y ayudaba, asistía y curaba las heridas físicas y morales. Muchas veces las heridas morales y espirituales antes y como condición para alcanzar la armonía y la curación de las enfermedades del cuerpo.

En un mundo tan dividido y roto por tantas ideologías, fundamentalismos, discriminaciones étnicas que generan odio, resentimiento y deseo de venganza, la capacidad de San Juan de Dios de perdonar, reconciliar y construir puentes de fraternidad merece ser estudiada y vivida por la Familia Hospitalaria. Entre todos, entre sus asistidos y sus Colaboradores, él era un profundo médico de heridas, tensiones y conflictos.

$\mathrm{Al}$ igual que Cristo, él también curaba las llagas. Sus biógrafos hacen notar cómo se sentía herido por la separación de sus padres, la soledad, las frustraciones de la vida militar, pero principalmente por sus culpas, las injurias sufridas, el sufrimiento por tantas deudas 
contraídas para ayudar a los pobres y a los enfermos, sus hermanos. Estas experiencias de heridas existenciales le convertían en un hospitalario especializado en curar y reconciliar a los enemigos entre ellos y a que llegasen a ser sus Colaboradores como ocurrió con Antón Martín y muchos otros.

A su bienhechora, la Duquesa de Sessa, decía que se curaba con las heridas de Cristo crucificado y la aconsejaba que hiciera lo mismo:

"Cuando me encuentro afligido, no encuentro remedio o consuelo mejor que mirar a Jesús crucificado" $"$.

"Recurrid a la pasión de Jesucristo nuestro Señor y... os llenará un gran consuelo"10.

Fue así cómo logró que Antón Martín perdonara y se reconciliara con Pedro Velasco y pudo conquistarlos a ambos para que fueran Colaboradores directos de su hospitalidad, como primeros Hermanos.

Y unido a la pasión de Cristo, los viernes, cuidaba las heridas de la prostitución a muchas mujeres destruidas por aquel género de vida. Por su carisma de hospitalidad misericordiosa perdonó a la mujer que arrancó de la prostitución y que lo injuriaba:"Antes o después tendré que perdonarte, entonces te perdono ahora mismo"11. Y así la convirtió una segunda vez, como ella misma rinde testimonio durante los funerales del santo.

Cuando lo acusan ante el arzobispo de acoger a gente indigna en su"Casa de Dios", se declara el único indigno y que" al igual que Dios tolera a los malos y a los buenos y cada día hace amanecer sobre todos su sol, no es razonable echar a los abandonados y a los afligidos de la propia casa"12.

9 GARCÍA BLANCO, Miguel, O.H. Cartas de San Juan de Dios. Texto original y transcripción moderna. Roma, 1987.

10 GARCÍA BLANCO, Miguel, O.H. Cartas de San Juan de Dios. Texto original y transcripción moderna. Roma, 1987.

11 GARCÍA BLANCO, Miguel, O.H. Cartas de San Juan de Dios. Texto original y transcripción moderna. Roma, 1987.

12 GARCÍA BLANCO, Miguel, O.H. Cartas de San Juan de Dios. Texto original y transcripción moderna. Roma, 1987. 


\section{G. Hospitalidad generadora de voluntariado y Colaboradores}

El amor misericordioso sin fronteras de San Juan de Dios tenía una vitalidad tan fuerte que generaba amor, caridad cristiana y colaboración; era hospitalidad luminosa, carisma siempre más participado.

Esta fuerza carismática recibida de Dios, a la que San Juan de Dios ha sido radicalmente fiel, ha convertido al santo en un fuego de luz hospitalaria a distintos niveles de solidaridad y colaboración con él en la ayuda a los pobres y enfermos.

Podemos distinguir varios niveles de Colaboradores: los que ayudaban con acciones o limosnas puntuales y los que se convirtieron en Colaboradores permanentes como Angulo y muchos otros citados en sus cartas, por Castro y, en el documento del Proceso contra los Jerónimos. Algunos abrazaron el voluntariado juandediano hasta la total pertenencia en la identificación con su carisma.

Entre los más estrechos Colaboradores contamos a sus primeros compañeros o hermanos de hábito, los bienhechores más identificados con su carisma que han hecho suya la Obra de San Juan de Dios. Y este sentimiento de pertenencia al hospital y a la Obra juandediana generaba, a su vez, una fuerte dinámica de solidaridad.

\section{H. Hospitalidad profética}

Una de las notas más originales de la Hospitalidad de San Juan de Dios ha sido la profecía. Sin medios, extranjero inmigrante con fama de loco, entregándose totalmente a Jesucristo y a los que sufren, abrió caminos nuevos en la Iglesia y en la sociedad.

Sus actitudes hospitalarias sorprendieron, desconcertaron, pero funcionaron como faros para indicar caminos nuevos de asistencia y humanidad hacia los pobres y los enfermos. De la nada creó un modelo alternativo de ser ciudadano, cristiano, hospitalario a favor de los más abandonados. Esta hospitalidad profética ha sido una levadura de renovación en la asistencia y en la Iglesia. El modelo juandediano ha funcionado también como conciencia crítica y guía sensibilizadora para actitudes nuevas y prácticas de ayuda hacia los pobres y marginados. 


\section{REGLAMENTACIÓN DE UN NUEVO ESTILO DE CUIDAR: PRIMITIVAS CONSTITUCIONES 1585}

La entrega incondicional de los Hermanos de San Juan de Dios y sus colaboradores que hemos visto a lo largo de la historia, tuvieron desde los comienzos un modelo inspirador en Juan de Dios. Pero en paralelo al paso del tiempo existió siempre el peligro de que se desdibujase aquel modelo de cuidar carismático. Así fue necesario reglamentarlo de modo que se preservaran las cuestiones claves; los valores principales que había que proteger para no perder la

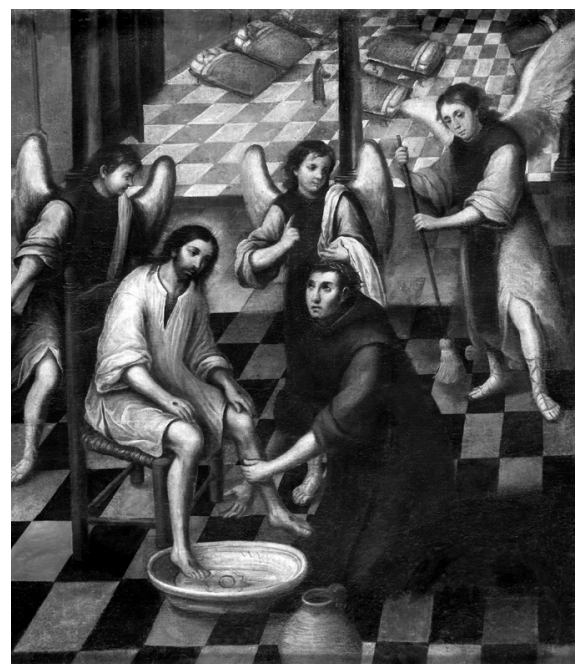
verdadera y auténtica identidad.

Volver a las primitivas Constituciones ${ }^{13}$ de la Orden, aquellas que practicaron los primeros Hermanos y que han ido evolucionando en el tiempo, pero manteniendo siempre lo genuino e identitario; nos da pie a comprender los basamentos de la entrega, asistencia y cuidado del enfermo en cualquier momento y situación. Más aún en esos tiempos y circunstancias que persiguen abordar este trabajo: las epidemias y pandemias.

\section{A. El enfermo ocupa el centro de nuestro interés}

"Y pues el principal instituto de este Hospital, es la cura y regalo de los pobres de Jesucristo, encargamos al dicho Hermano Mayor que es o fuere de aquí en adelante, sea manso, piadoso, caritativo con los pobres, se duela mucho de sus enfermedades y trabajos, no se disguste ni reciba pesadumbre de las importunidades de ellos, antes los regale y consuele con palabras amorosas, y obras caritativas, y así con procurar se les acuda con el sustento necesario de día y noche conforme a la calidad de las enfermerías, como

13 Primitivas Constituciones de la Orden Hospitalaria. Granada: En casa de Hugo de Mena; 1585. Edición facsímil: Madrid: Orden Hospitalaria. Provincia Castilla, 1977. 
también con la ropa de las camas que sea limpia, de suerte que con el regalo que se les hiciere, con facilidad recuperen la salud".

\section{B. La higiene como principio básico de cuidado}

"Los enfermeros tendrán cuidado de cuando se recibe el enfermo pobre, que lo acuesten en la cama si fuere posible lavarle la cara y las manos, cortarle el cabello y uñas, y si no perjudicare a su salud, lavarle las piernas de suerte que esté con mucha limpieza, y después de todo esto lo acostará en la cama bien aderezada con sábanas y ropa limpia, almohadas, escofieta, y camisa del hospital si el enfermo no lo trajere; todo lo cual se mudará cada ocho días como se declara en el título de la ropería".

"Tendrán cuidado de sacar los servicios cada mañana, y si hubiere necesidad dos veces y más cada día, por que el mal olor no infecte la sala, y ofenda a los enfermos y a los que los visitan [...] y así mismo tendrán cuidado de perfumar cada día tres veces las salas por las mañanas y a mediodía, y a la noche y más veces si fuere necesario, y será con romero si no hubiere otra cosa mejor".

\section{Especial atención al final de la vida. "Ayudar a bien morir"}

“Tendrán cuidado de avisar al rector si alguno estuviere en peligro, para que le de los santos Sacramentos, y entretanto que los traen aderezarán las salas donde estuvieren los tales enfermos, y pondrán en los altares de madera que para este efecto tendrán el recaudo y aderezo que tienen para este efecto, donde ponga la custodia del Santísimo Sacramento y sahumarán las salas con los perfumes acostumbrados, y si después la enfermedad fuere agravándose más harán lo que en sí fueren, asistiendo con ellos en aquel punto y trance riguroso de la muerte, ayudándoles a bien morir, repitiendo muchas veces el Credo, y esparciendo agua bendita por la sala, leyéndoles las oraciones de bien morir que están en la tablilla para esto dispuesta, y ponerles han asimismo un Cristo en las manos y tendrán lumbre encendida."

\section{Buenas prácticas y excelencia en el cuidado}

"Los enfermeros dormirán en las salas de los dichos enfermos, para acudir con brevedad a las necesidades de ellos, y para esto velarán por sus turnos y horas de la noche, de suerte que por su descuido o negligencia no muera alguno solo, o se descobije, o se caiga de la cama, o haga otra cosa indecente que se pudiera reparar con la ayuda y asistencia de los dichos enfermeros". 


\section{E. Sacralización de la cura y cuidado / humanización de la asistencia}

"Y encargamos a los dichos médicos y cirujano tomen con paciencia el curar los enfermos, visitándolos con quietud, sosiego y despacio, informándose de sus enfermedades mansa y caritativamente para aplicar mejor el remedio y medicina que conviniere, poniendo ante los ojos de su entendimiento que es Jesucristo nuestro Redentor el que está curando, y haciéndolo así, él se los alumbrará, para que acierte aquellas y otras curas, y les pagará el ciento por uno, como lo tiene prometido"

\section{LA ORDEN DE SAN JUAN DE DIOS Y SU INTERVENCIÓN EN EPIDEMIAS Y PANDEMIAS. CRONOLOGÍA DE UNA DINÁMICA CONSTANTE DE ENFERMEDAD /CUIDADOS Y CURACIÓN}

Los Hermanos de San Juan de Dios a lo largo de su historia han "plantado cara" a las enfermedades más amenazantes por las que ha pasado la sociedad. La deficitaria estructura sociosanitaria hasta bien entrado el siglo XX en España en muchos casos y ocasiones, únicamente quedaba resuelta por los hospitales de San Juan de Dios.

El problema de las epidemias, y esto lo estamos experimentando en primera persona en estos momentos nosotros mismos, no solo era sanitario sino también social. Hoy estamos hablando de la crisis sanitaria versus crisis social y económica. En otro tiempo las expresiones varían pero la realidad es parecida: junto a una epi demia emergía el problema de una hambruna. Las epidemias generaban terror, desolación, además de rapiñas, crueldad y al tiempo que emergía la "solidaridad" también aparecía la maldad por parte de malhechores y gente sin escrúpulos.

En otro tiempo, no muy lejano, toda enfermedad epidémica era denominada genéricamente con el nombre de peste. De ahí el término despectivo de apestado. La ciencia ha ido avanzando, el conocimiento se ha ido abriendo paso y se ha acumulado, llegando a denominar con infinita concreción el nombre exacto de la enfermedad que nos acecha.

El orden, la disposición y el atajo en definitiva de la enfermedad, históricamente quedaba en manos de un modelo de autoridad muy arbitraria y poco jerarquizada, con escasa capilaridad para acceder a poblaciones o rincones geográficos alejados de las grandes 
urbes. Las estructuras hospitalarias, deficientes o inexistentes en muchos casos y momentos, quedaba en manos de la autoridad religiosa como obispos y arzobispos.

Hoy día difícilmente se puede apreciar en todo, su providencial valor, la utilidad y la necesidad de la labor que las instituciones de iglesia han prestado en las calamidades públicas.Y es impensable sobre todo en los países desarrollados, en los que el Estado, poseyendo los medios y poderes necesarios, siente el deber de legislar para asegurar a sus ciudadanos la mejor asistencia social. ${ }^{14}$

Enumerar los escenarios epidémicos donde ha desempeñado su servicio la Orden Hospitalaria no resulta una tarea fácil. La actividad hospitalaria de la institución ha generado una cultura de la acción, la inmediatez, descuidando la atención a documentar estos acontecimientos que se afrontaban desde el convencimiento de una entrega consagrada al servicio del prójimo. Hoy valoramos y seguimos profundizando en los documentos que aportan conocimiento y luz sobre estas acciones. Más aún cuando estamos asistiendo a una realidad con tantos paralelismos con otros acontecimientos ya pasados.

La documentación con la que contamos para abordar esta investigación es fragmentaria y no siempre directa y de primera mano. Pero no obstante cronistas, archiveros e historiadores sobre todo de la Orden - nos han ofrecido suficientes datos para poder reconstruir cronológicamente un "currículo" de actuaciones en epidemias que sigue asombrando. En estos casi cinco siglos de existencia y asistencia, la Orden Hospitalaria se ha distinguido en este campo, modestamente pero con decisión y con mucha eficacia y repercusión.

Las fuentes internas de la Orden no siempre se refieren con rigor al nombre de la epidemia, denominándola de modo genérico como "peste". Hoy estos episodios infecciosos sabemos con rigor que tuvieron otro nombre pero, nuestro objetivo no persigue entrar en el detalle de la denominación científica específica, ya que para

14 RUSSOTO, Gabriel. MUÑOZ MARTÍNEZ, José Luis O.H. (trad.). San Juan de Dios y su Orden Hospitalaria. Segundo volumen. Granada: Archivo-Museo San Juan de Dios “Casa de los Pisa”, 2012. Colección Temas Históricos O.H. 
profundizar en ello podemos recurrir a otras fuentes más dirigidas a estudiar este asunto. ${ }^{15}$

Pasemos a citarlas siguiendo un orden cronológico.

\subsection{La escasez y miseria de los primeros siglos:}

\section{EPIDEMIAS SIN NOMBRE PROPIO}

\section{LA EPIDEMIA DE “CATARRO” $\{1580\}$}

La primera actuación de los Hermanos de San Juan de Dios en una epidemia, la encontramos citada de modo muy breve en una de las crónicas de la Orden. Se refieren a ella como epidemia de "catarro" aunque sin duda se querían referir a la peste.

"... al mismo tiempo había cundido en España una enfermedad, a que se daba el nombre de catarro, pero que llevaba infinitas personas al sepulcro. Llegó el caso de haber muchos pueblos en que los enfermos no tenían quien los asistiese: los padres abandonaban a sus hijos, los maridos a sus mujeres; unos por temor del contagio, otros porque ya participaban de sus efectos. Angustiado en tal conflicto el piadoso corazón del Monarca [Felipe II], escribió a las diversas casas de la Orden, para que sus individuos se repartiesen por los lugares más necesitados para asistir y curar a los enfermos: obedecieron con la mayor puntualidad, cumpliendo con sus obligaciones con al esmero, que muchos de ellos fueron víctimas de su ardiente caridad". ${ }^{16}$

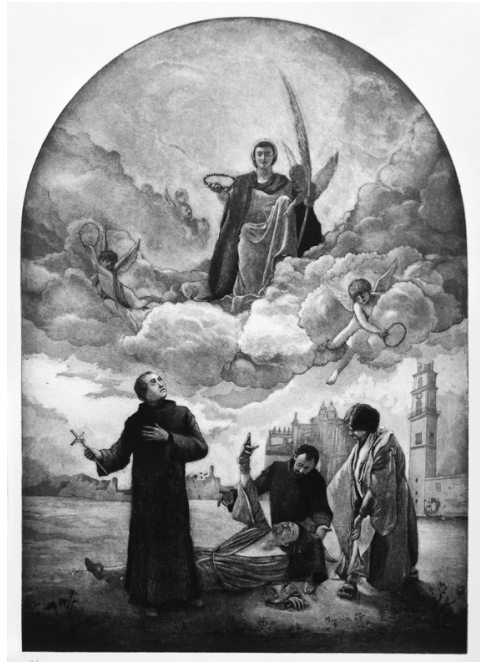

15 MONTALDO. Federico. Libro de las epidemias. Madrid: Ed. Manuel Soler, 1973. QUAMMEN, David. Contagio. La evolución de las pandemias. Madrid: Debate, 2020.

16 GIL ROLDÁN. Carlos. O.H. Glorias de los Hijos de San Juan de Dios N.P. de la Congregación de España. Noticias históricas de los servicios que a Dios y al Rey han hecho desde su fundación en tiempo de calamidades públicas, de guerra y peste. Madrid: Tipografía de la viuda de Ibarra, $1796 .$. 
Y es que un denominador común en todas las actuaciones de la Orden en el atajo y remedio de estas epidemias, será la pérdida de efectivos en el ejercicio del voto de hospitalidad. Respondiendo con fidelidad a su vocación y a las Constituciones profesadas. En todas las ocasiones de un modo heroico y que llegan a constituir en muchos casos un modelo a seguir cuando no un modelo de santidad.

Así es el caso del hermano Juan Grande. Hoy reconocido por la Iglesia como San Juan Grande.

\section{EPIDEMIA DE PESTE EN JEREZ DE LA FRONTERA $\{1600\}$}

El Hermano Juan Grande ${ }^{17}$, quien años antes había liderado la reorganización de los hospitales de Jerez de la Frontera junto a un nutrido número de Hermanos. Respondió a las necesidades de los enfermos de Jerez apestados en 1600. Su experiencia se remontaba al servició prestado en anteriores episodios de peste en la ciudad de Jerez y otros pueblos de la provincia de Cádiz (1574 y 1589). Además de otros episodios donde estaban afectados soldados de las tropas portuguesas que regresaban de África. Su servicio hospitalario lo prestó con tanta generosidad y entrega que se contagió de peste y falleció en el año 1600. Hoy está reconocido por la iglesia como un hombre santo. Un modelo de hospitalario a seguir.

\section{LA PESTE EN GIBRALTAR $\{1618\}$}

El movimiento de naves que trasladaban soldados fue especialmente un medio de expansión de la enfermedad en otros siglos. Así, en esta fecha, la peste estalló en el regimiento de infantería español compuesto por napolitanos. En las naves que fueron para asistir a los enfermos iba fray Alonso de la Concepción con otros Hermanos; quedándose en tierra para prestar sus servicios el Prior del hospital de la Orden en la misma ciudad, fray Cristóbal Macías y sus religiosos. Murieron ocho hospitalarios en este generoso servicio de caridad. ${ }^{18}$

17 REPETTO BETES, José Luis. Jerez tiene un Santo. Jerez de la Frontera: Unión de cofradías de Jerez. Caja San Fernando, 1997.

MASCARENAAS, Gerónimo. Vida, virtudes y maravillas del Beato Juan Grande de la Orden Hospitalaria de San Juan de Dios. Madrid: Imp. del asilo de huérfanos del S. C. de Jesús, 1929

18 SANTOS, Juan O.H. Chronología Hospitalaria y resumen historial de la Sagrada religión del Glorioso Patriarca San Juan de Dios. Madrid, 1715. 


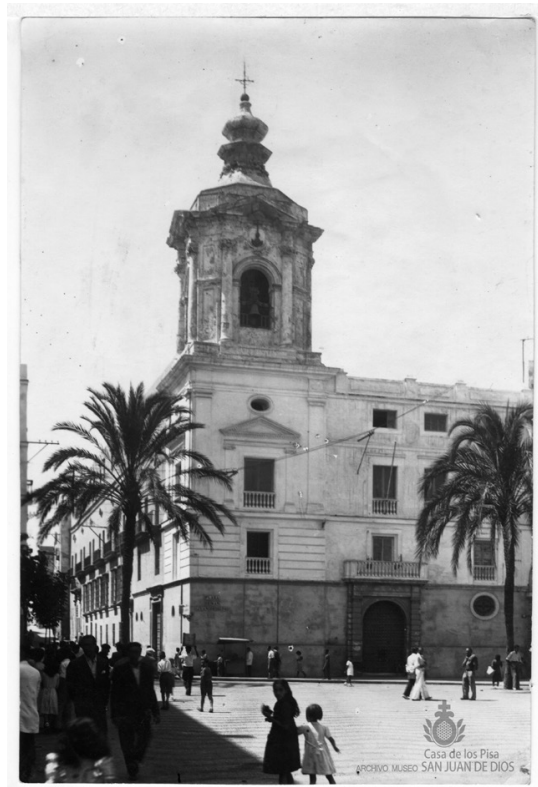

\section{EPIDEMIA DE TIFUS EN CADIZ $\{1636\}$}

La ciudad de Cádiz con una situación estratégica privilegiada y con un trasiego importante de viajeros a ultramar, ha sido escenario de diferentes episodios de infección y contagio de numerosas enfermedades. La presencia de la Orden en la ciudad se remonta a los primeros años después de la fundación en Granada. En este año fue necesario que los hermanos implantaran en la ciudad además del ya existente, seis hospitales provisionales más para asistir en ellos a los soldados que habían contraído la peste o tifus petequial. La enfermedad había estallado a causa del hacinamiento de las tropas mientras se preparaba la flota destinada a ir contra Francia y Holanda. La mortalidad diaria era de 12 a 14 soldados. Sobrecargados de trabajo, los religiosos pidieron ayuda al Superior Provincial: Justiniano Sánchez de Alberola, quien acudió personalmente con otros seis Hermanos. En este brote epidémico murieron víctimas de su caridad siete Hermanos. ${ }^{19}$

\section{EPIDEMIA DE PESTE EN MÁLAGA \{1637\}}

Las diferentes epidemias que asolaron a la ciudad de Málaga durante el siglo XVII ocasionaron la expansión de la Orden Hospitalaria en esta provincia. Sus actuaciones, en muchas ocasiones heroicas, su estilo de organización y las aportaciones novedosas a la farmacopea del momento, con remedios y medicinas, fueron sus mejores credenciales para confiarles la asistencia sanitaria en hospitales de origen real en Málaga y provincia.

19 GÓMEZ BUENO, Juan Ciudad, O.H. Necrologio de la Orden Hospitalaria. Actualizado por MUÑOZ MARTÍNEZ, José Luis, O.H. Granada: Archivo Museo San Juan de Dios"Casa de los Pisa”, 2021. 


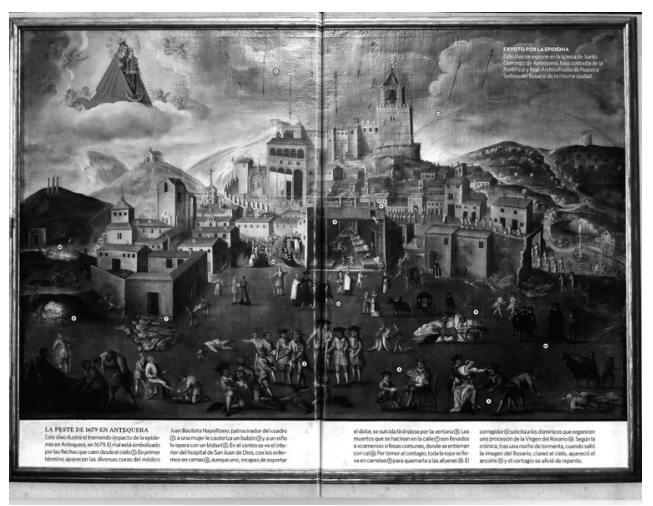

La epidemia de peste de 1637 supone la primera incursión de los Hermanos de San Juan de Dios en la ciudad. Llegan desde la cercana ciudad de Granada y en un plazo breve de tiempo logran curar a los enfermos y establecer medidas profilácticas. Sería la epidemia de peste de 1677 en la que los Hermanos de San Juan de Dios llegarían a la ciudad ya para quedarse. La ubicación del Hospital de San Juan de Dios en el barrio de la Cruz Verde, sería el lugar ideal por estar alejados o en el extrarradio de la ciudad y tener una buena orientación a las influencias de vientos del Norte. La evolución de la enfermedad en este Hospital durante los dos años de epidemia (1677-78) puede seguirse a través de los resúmenes de los informes que enviaron tanto al obispo como el corregidor de Málaga al Consejo de Castilla. Del contenido de los mismos se deduce, a niveles generales, la persistencia de la enfermedad durante el período con intervalos de recuperación y recaída. La información cotejada tiene su punto de partida en el informe enviado por el obispo el 12 de noviembre de 1678 a don García Fernando Bazán, que acaba de llegar a Antequera para disponer el cordón sanitario a Málaga. Desde esta fecha fueron asistidos en el Hospital San Juan de Dios de Málaga 684 enfermos y murieron 346, lo que arroja una mortandad del $50,6 \%$ sobre los pacientes, porcentaje muy inferior al $80 \%$ que vimos en la epidemia murciana. El punto álgido de la epidemia fue en la semana del 15 al 21 de noviembre de 1678, registrándose un total de 74 enfermos ingresados a los que se unían los 164 ya existentes. Los fallecidos fueron sesenta y tres. En los dos meses siguientes se experimentó una progresiva mejoría que hizo esperar la extinción de la epidemia para el mes de febrero, pero la euforia fue transitoria ya que a finales de marzo de 1679 se reavivó el contagio y el Consejo recordaba las órdenes emanadas para la guarda de la Corte.

Entre los Hermanos destacados por sus conocimientos en medicina y cirugía que actuaron en esta epidemia y de los que tenemos noticia podemos citar a: fray Francisco de la Cruz y fray Juan de Calmaestra. 
Ocuparon cargos directivos en los hospitales de apestados de la provincia de Málaga. El primero de ellos tenía renombre por sus conocimientos de las pestes de Sevilla, Barcelona, Bruselas y Malinas de Flandes, por sus cualidades profesio-

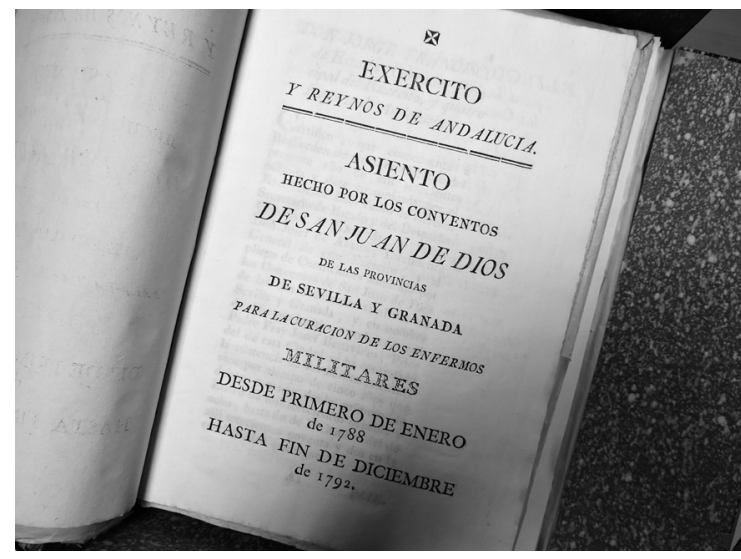
nales desempeñó las categorías de Administrador General de los Hospitales Reales del Ejército. A su llegada a Málaga, el obispo le encargó la dirección y gobierno del Hospital de la Cruz Verde, nombrándolo Superintendente del mismo. Desconocemos el motivo pero al poco tiempo de la toma de posesión de la Orden del Hospital Real de la Caridad de Málaga por los religiosos de San Juan de Dios (enero 1679) presentó su dimisión y solicitó del obispo Santo Tomás "le dexasse por enfermero y guarda ropa, en que se ocupa actualmente".$^{20}$

En este caso que a continuación reseñamos, propio de una ciudad portuaria con un importante trasiego de buques. En los primeros días de 1794, zarparon desde Barcelona para las Islas Canarias cuatro embarcaciones cargadas de prisioneros franceses. El comandante tuvo que interrumpir el viaje al estallar entre los prisioneros un contagio del que se ignora su naturaleza, y se paró en el puerto de Málaga. Encontraron dificultades insuperables para montar un lazareto en tierra. Se decidió entonces dejar a los contagiados en las naves, casi abandonados a su suerte. El Prior del Hospital de los Hermanos de San Juan de Dios, Fray Juan Rando, se ofreció, junto con sus religiosos, para asistir en los barcos. Los hospitalarios que estaban situados frente al puerto, comenzaron la asistencia el 18 de febrero, llevando a los enfermos vestidos limpios, alimentos y medicinas y más todo aquello que necesitaron. El 11 de marzo se pudo

20 ZAMORA BERMÚDEZ, Manuel. Estructura benéfico-sanitaria en la Málaga de fines del siglo XVII. Hospitales de San Julián y San Juan de Dios. Málaga: Universidad de Málaga. Excma. Diputación Provincial de Málaga. 1987. 




trasladar a los contagiados al Castillo de Grijalfaro. Los Hermanos continuaron asistiéndolos con todo detalle hasta la total extinción del contagio, el 24 de mayo. Durante los tres meses ininterrumpidos de asistencia, ningún Hermano contrajo la enfermedad. La Junta de Sanidad y el Gobernador de la Plaza tuvieron palabras de elogio para la obra de caridad que habían realizado y se lo refirieron directamente al Rey. ${ }^{21}$

\section{LA EPIDEMIA DE PESTE EN ANDALUCÍA Y OTRAS REGIONES $\{1648\}$}

Los años comprendidos entre 1648 y 1650 supusieron también una dura prueba para la población de Andalucía, Murcia y Valencia. El necrologio ${ }^{22}$ de la Orden hace balance de los hermanos fallecidos en estos años por esta epidemia de peste mientras asistían a los enfermos infectados. En Sevilla murieron 22. En Utrera, todos los religiosos de la comunidad. En Murcia, los 20 Hermanos que formaban la familia religiosa y otros 24 Hermanos que habían sido mandados por el Provincial de Castilla. En Córdoba 7, incluido el Hermano Superior. En Orihuela, los 6 religiosos de la comunidad. En tres años de epidemia el número de víctimas de la caridad llegó a 114. Entre ellos hay que señalar de forma particular al Hermano Fernando Lanzas y al Hermano Juan Herrera, experimentados cirujanos, que aun estando ya infectados en el hospital de Sevilla, continuaron asistiendo heroicamente a los apestados, sin sucumbir por ello. ${ }^{23}$

21 GIL ROLDÁN. Carlos. O.H. Glorias de los Hijos de San Juan de Dios N.P. de la Congregación de España. Noticias históricas de los servicios que a Dios y al Rey han hecho desde su fundación en tiempo de calamidades públicas, de guerra y peste. Madrid: Tipografía de la viuda de Ibarra, 1796.

22 CIUDAD GÓMEZ, Juan, O.H. Necrologio de la Orden Hospitalaria. Actualizado por MUÑOZ MARTÍNEZ, José Luis, O.H. Granada: Archivo - Museo San Juan de Dios"Casa de los Pisa", 2021.

23 SANTOS, Juan O.H. Chronología Hospitalaria y resumen historial de la Sagrada religión del Glorioso Patriarca San Juan de Dios. Madrid, 1715. 


\section{LA EPIDEMIA DE VÓMITO NEGRO EN CADIZ $\{\mathbf{1 7 3 0}\}$}

Durante este episodio los Hermanos acogieron en el Hospital de Cádiz el ingente número de 756 contagiados, manteniendo durante meses un extenuante trabajo asistencial de día y de noche. Murieron 346 enfermos y diez Hermanos que los asistían. Esta misma enfermedad en años sucesivos se extendería por Málaga y Montalbán, Granada, Jaén, Pinto y Alcalá de Henares donde los Hermanos de San Juan de Dios prestarían sus servicios.

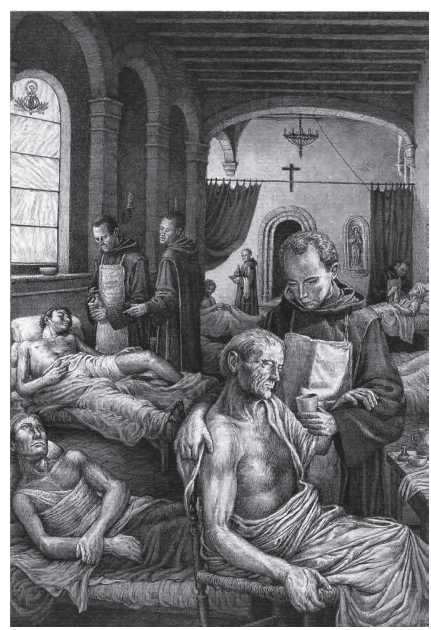

\section{LA EPIDEMIA DE PESTE EN CEUTA Y EL PEÑON DE GIBRALTAR \{1753\}}

Las autoridades sanitarias españolas pidieron la ayuda de los Hospitalarios para afrontar una violenta epidemia que se había desencadenado en las plazas fuertes de la costa africana: Ceuta y el Peñón. El General de la Orden en ese momento, P. Alonso de Jesús Ortega, mandó 18 Hermanos a Ceuta en dos veces y 4 al Peñón, escogiendo los primeros 8 de Granada, Málaga, Córdoba. Después escribió a los demás conventos-hospitales de España pidiendo Hermanos que se ofrecieran voluntariamente, enseguida le llegaron 40 cartas de religiosos que se ofrecían para la asistencia a los contagiados. A continuación siguió otro número considerable de adhesiones voluntarias. Los hermanos fallecidos en el ejercicio de la hospitalidad fueron 11 en Ceuta y uno en el Peñón. ${ }^{24}$

\section{LAS PRIMERAS VACUNAS. EL DR. BALMIS Y EL HERMANO CHAPARRO $\{1765\}$}

El 13 de diciembre de 2007 la Orden Hospitalaria recibía el III Premio Balmis que otorga Sanidad Militar Española en conmemoración del bicentenario de la Expedición Balmis que en el año1803 llevó la vacuna de la viruela a las tierras de América.

24 CIUDAD GÓMEZ, Juan, O.H. Historia de la Orden Hospitalaria de San Juan de Dios. Granada: Archivo - Museo San Juan de Dios"Casa de los Pisa", 1963. 


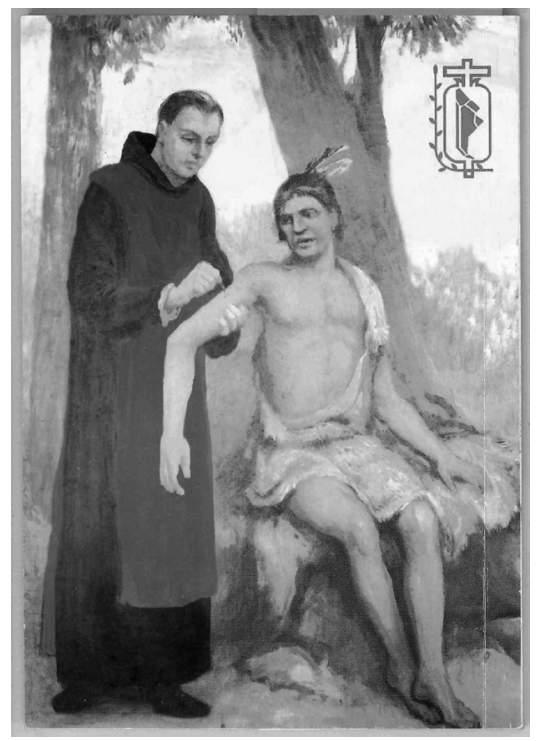

El Dr. Balmis, nacido en Alicante el 2 de diciembre de 1753 y fallecido en Madrid el 12 de febrero de 1819. Médico militar español, cirujano honorario del rey Carlos IV. Su nombre ha quedado vinculado a la expedición que realizó en 1803 hacia las colonias españolas de América y Filipinas, conocida como la Real Expedición Filantrópica de la Vacuna de laViruela o Expedición Balmis, para difundir la vacuna de la viruela, un hito en la historia de la medicina.

La viruela era una enfermedad mortal que arrasaba pueblos y ciudades de cualquier parte del mundo. La vacuna antivariólica fue descubierta por el médico inglés Dr. Edward Jenner en 1798 e inmediatamente el Dr. Balmis se empeña en la tarea más noble posible entre los humanos de ponerse al servicio de los enfermos y de los que sufren para aliviarlos y en la medida de lo posible devolverles la salud. En su caso a la misión de portar aquella vacuna que tanta esperanza y vida significaba para el mundo, especialmente en aquel momento en América y Asia. Una Expedición que fue promovida por el rey de España Carlos IV y llevada adelante por el Cuerpo Sanitario del Ejército de la nación, realizando claramente una Expedición para la vida, a favor de la salud de los pobres y enfermos, en definitiva algo que hoy definimos como una Expedición humanitaria, al servicio de las personas y de los pueblos. El Dr. Francisco Javier Balmis fue el responsable de llevar a buen puerto tan noble Expedición. Entre los miembros destacados de la Orden Hospitalaria en América está Fray Pedro Manuel Chaparro ${ }^{25}$, médico chileno contemporáneo del Dr. Balmis, que destacó también por su lucha contra la viruela en su país natal y que fue testigo de primera mano de la Expedición que

25 CERVERA, Manuel. Cinco españoles olvidados que cambiaron el mundo luchando contra epidemias y salvado miles de vidas. En: ABC. 16 marzo 2020. [Erróneamente afirma que Pedro Manuel Chaparro era español. También ignora que era religioso profeso de la Orden Hospitalaria de San Juan de Dios en Chile.] 
de España llegó a aquellas tierras. De hecho lo encontramos en Santiago de Chile, años antes del descubrimiento de la vacuna, en 1765, tratando a las personas que la padecen y, muy importante, haciendo un gran trabajo de prevención de la misma a través de inoculaciones de pus de las pústulas de los variolosos para prevenir la viruela, salvando de este modo muchas vidas. No conocemos el método que utilizaba si bien existen algunos datos en un libro publicado en Lima en 1778, titulado Inoculación de las viruelas. Por otra parte Lorenzo Quiñones en 1797 describe el método usa-

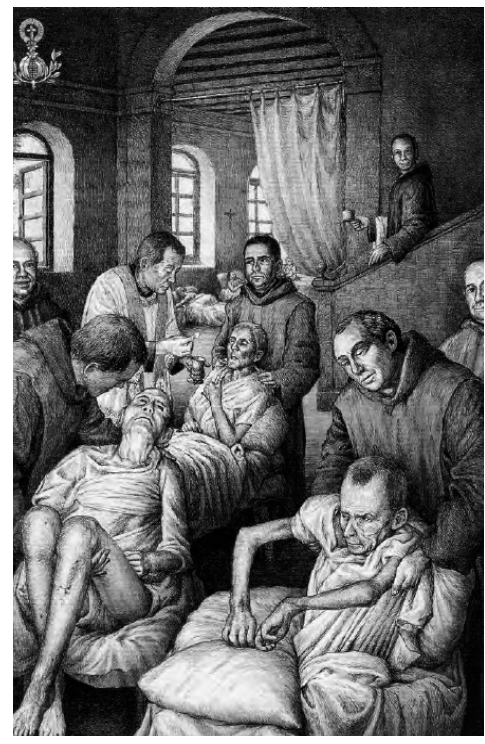
do en Perú y que parece debió ser muy similar al utilizado por el Hermano Chaparro ${ }^{26}$.

\section{EPIDEMIA DE FIEBRE AMARILLA $\{1800\}$}

En el año 1800 comenzó la fatal epidemia de fiebre amarilla que azotó durante varios años a España, Portugal e Italia.

Las regiones españolas más flageladas por el morbo fueron Andalucía y Murcia. En tres meses, Andalucía tuvo 80.000 muertos. En Cádiz, solo en un año, los decesos llegaron a 10.000. En España murieron en total 140.000 contagiados $^{27}$.

$\mathrm{Al}$ igual que en las anteriores epidemias, también en esta, no pocos Hermanos cayeron víctimas de la fiebre amarilla mientras ejercían su fraterna asistencia. En el lazareto de Cádiz murieron el P. Carlos Gil Roldán. Fray Antonio Baeza y Fray Antonio Sánchez, parece ser que en 1800; en Málaga, Fray Manuel Herrera y Fray Francisco Cordón, 1803; en Murcia, entre otros, Fray Miguel Roa y Fray Gil Mirón, Prior de Madrid, 1811.

26 BONDONI, E., Vida y obra de Fray Pedro Manuel Chaparro. Ramos Mejía, 2007. Entrega del premio Balmis a la Orden Hospitalaria de San Juan de Dios. En: Boletín Interprovincial Fundación Juan Ciudad, noviembre-diciembre 2007, nº 75, pp. 1-4.

27 PUNTONI, Victoriano. Trattato d'igiene. Tomo II. Roma, 1948.. 
Hay que recordar también con admiración la abnegación y el fervoroso celo pastoral por aliviar a los contagiados, demostrado en Cádiz por el P. Pedro Rosa, sacerdote hospitalario a pesar de sus 74 años y numerosos achaques debidos a la edad.

\section{EPIDEMIA DE TIFUS EN CEUTA $\{1800\}$}

En este mismo año hay que señalar otra generosa prestación en Marruecos, en la ciudad de Ceuta, para una epidemia de tifus. Fueron veinte religiosos hospitalarios de los que murieron 13 al contraer la enfermedad asistiendo a los enfermos. Como en otras ocasiones los religiosos hospitalarios aun a pesar de no tener convento-hospital en Ceuta acudían a la llamada de las autoridades para asistir en hospitales (a veces provisionales) a los enfermos.

\section{EPIDEMIA DE TIFUS EN EL PUERTO DE SANTA MARIA \{1819\}}

Debido a los acontecimientos políticos de la primera mitad del siglo XIX, que culminaron con la supresión de las Órdenes religiosas, la presencia de los Hermanos en las epidemias en España fueron menos frecuentes de las que tuvieron lugar en siglos anteriores.

En un acta notarial redactada por Isidoro Ortega Salomón en 1854, se hace referencia a algunas prestaciones sanitarias de la Orden a primeros del 800, y se recoge una declaración de la Junta Municipal del Puerto de Santa María, de fecha 20 de diciembre de 1819, certificando la labor de los Hermanos, especialmente del Prior,cuando la epidemia de tifus amenazó la ciudad".

Entre las medidas adoptadas, la Junta erigió un hospital provisional a las afueras de la ciudad, confiándolo al Prior de los Hermanos de San Juan de Dios. La Junta sintió enseguida el alivio y la ventaja de ello, entre otras cosas gracias al desinterés mostrado por el Prior que rechazó la cantidad que el Ayuntamiento debía asignar por cada enfermo, "contentándose sólo con que le suministraran lo estrictamente necesario". El prior, aunque dirigía dos hospitales - uno civil y otro militarcon muchas camas, atendió con el máximo celo no sólo el lazareto, sino también la asistencia voluntaria a los enfermos"en sus propias casas".

\section{EPIDEMIA DE CÓLERA EN 1832}

La nueva epidemia que apareció en el siglo pasado y que azotó varias veces Europa fue el cólera. La fuente endémica de este morbo, como se sabe, se encuentra en la India, en el estuario del río Ganges, 


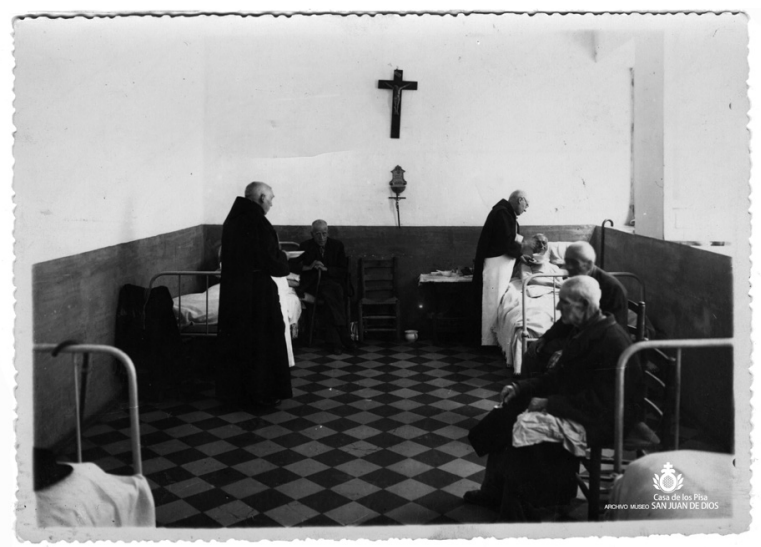

en Bengala, no lejos de Calcuta. De aquí se extendió y difundió a otras partes, con alguna puntada incluso en América. La primera vez que apareció en Europa fue en 1817. Los historiadores engloban las epidemias coléricas más importantes en Europa entre 1817 y $1926{ }^{28}$

Al ser invadida por el cólera también España del 1832 a 1834, los religiosos hospitalarios se dedicaron generosamente en varias ciudades a la asistencia y cuidado de muchos pobres enfermos, a pesar de las brutales escenas del sangriento odio sectario contra el clero y las órdenes religiosas.

Nada más aparecer el cólera, los anticlericales revolucionarios levantaron al pueblo contra los religiosos, diciendo que habían sido estos quienes habían provocado y difundido la terrible epidemia. Tanto en Madrid como en otras ciudades, fueron saqueados los conventos, cometidas profanaciones, incendios, destrucciones, y no pocos religiosos fueron asesinados en medio de una terrible confusión. Los Hermanos de San Juan de Dios, se multiplicaron prodigando el bien y llevando el socorro y el consuelo a cuantas partes era posible. Quedan abundantes testimonios de su admirable comportamiento en aquellos terribles años, como veremos a continuación.

\section{EPIDEMIA DE CÓLERA EN MEDINA SIDONIA \{1834\}}

Estallado el cólera en Medina Sidonia(Cádiz), los Hermanos asumieron la dirección y la asistencia de un lazareto instalado a las afueras de la ciudad.

28 PUNTONI, Victoriano. Trattato d'igiene. Tomo II. Roma, 1948. 


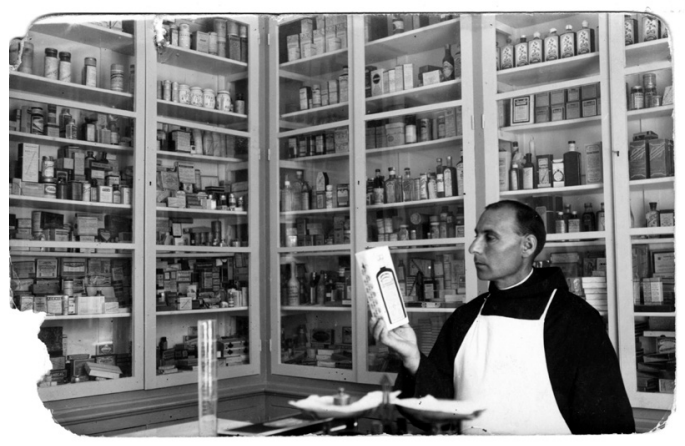

La Junta Municipal de Medina, que se lo había confiado, atestiguó públicamente, mediante un documento del 20 de octubre de 1834, su actividad para consuelo de los enfermos de cólera, tributando, a través de su Alcalde Mayor, un vibrante elogio, especialmente al Hermano Superior, porque "despreciando el peligro eminente de sus vidas, se ha visto a estos perfectos imitadores del Santo Patriarca (San Juan de Dios) velar incesantemente a la cabecera de los enfermos, preparar y darles con cariño las medicinas y alimentos, manejarlos en la cama con dulzura, limpiar sus inmundicias y darles con la más santa eficacia todos los socorros".

Sobre todo del prior, el alcalde admira y subraya con profunda edificación, que además de dirigir el hospital de la Orden y asistir a los enfermos del barrio, se dedicó con gran impulso de caridad al lazareto, "lo dispuso a sus expensas con tal aseo, esmero y profusión cual no se vería el de ninguna capital". Pero lo más "notable y edificante" fue "ver la cama del Prior igual y entre la de los enfermos".

El cronista, Fray Luciano del Pozo concluye este periodo que precede la restauración de la Orden en España, diciendo:"en idéntica forma tenemos ante la vista testificaciones de Jerez de la Frontera, Puerto de Santa María, Sevilla, La Habana, Palencia, Lorca, Valladolid, Málaga, Cabra, Montilla, Vélez-Málaga, Marbella, Bujalance, Andújar y Jaca".

\subsection{Tras la desamortización y restauración de la Orden:}

\section{EPIDEMIAS DE CÓLERA Y VIRUELA}

Los procesos desamortizadores de Medizabal, como a tantas instituciones religiosas, a la Orden Hospitalaria le supuso un duro gol$\mathrm{pe}^{29}$. Prácticamente quedó extinguida la Orden en España y América. A pesar de lo convulso de este momento, en el que ya estaba

29 REVUELTA GONZÁLEZ, Manuel. La exclaustración (1833-1840). Madrid: BAC, 1976. 
amenazada de muerte la Orden, no faltaron como hemos visto anteriormente, testimonios ejemplares del ejercicio de la hospitalidad en crisis sanitarias y sociales propiciadas por diferentes epidemias.

El complejo proceso de restauración de la Orden Hospitalaria

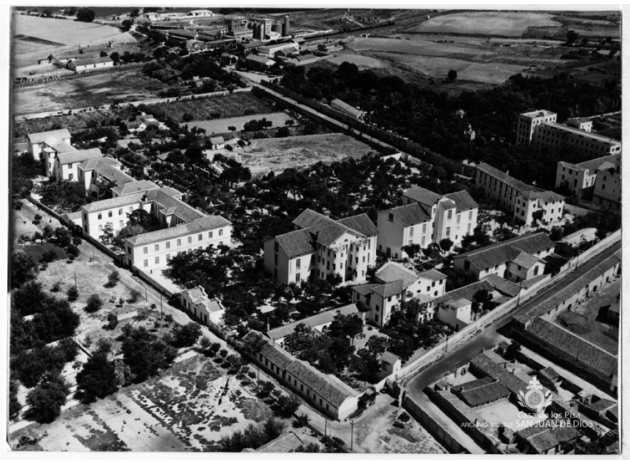
en España, Portugal y América, tendría que esperar hasta treinta y tres años (1835-1868). El Superior de la Orden, con sede en Roma, Hermano Juan María Alfieri ${ }^{30}$, tras diferentes intentos logró acertar con la persona que desempeñaría ésta difícil empresa. Un joven italiano llamado Benito Menni ${ }^{31}$. Desde muy temprano, este joven profeso hospitalario dio claras señales de que podría levantar la desaparecida Orden Hospitalaria en España. Comenzó su trabajo en la ciudad de Barcelona y pronto crearía comunidades y centros hospitalarios por diferentes puntos de la geografía española. Granada, Sevilla, Ciempozuelos...

Como podemos ver a continuación. Su época no estuvo exenta de enfermedades y necesidades. Su intervención fue determinante en la epidemia de cólera que invadió nuestro país en 1885 y una vez más, su actuación y la de la joven y entusiasta Orden Hospitalaria que había logrado "reconstruir" en España dio claro ejemplo de su opción preferencial por los enfermos, al estilo de San Juan de Dios.

\section{LA CAMPAÑA ANTICOLÉRICA EN ESPAÑA $\{1885\}$}

España sufriría una grave epidemia de cólera morbo de 1885 y una vez más podemos relatar la heroica actuación de la Orden Hospitalaria en esta ocasión, como hemos visto anteriormente. La realidad de la institución es muy diferente a la que existía antes de los procesos

30 VALERO HURTADO, Luis. El P. Giovanni MariaAlfieri y la reforma de la Orden Hospitalaria de San Juan de Dios en el siglo XIX. 1862-1888. La santidad en tiempos de crisis. Granada: Archivo-Museo San Juan de Dios "Casa de los Pisa", 2014. Colección Temas Históricos O.H.

31 GÓMEZ BUENO, Juan Ciudad. El resurgir de una obra. Granada: Archivo Interprovincial, 1950. 
desamortizadores. Pero los ideales, los valores y los basamentos principales de una institución que persigue evangelizar en el mundo del dolor, se han renovado y están más fuertes que nunca. El servicio que prestan los Hermanos de San Juan de Dios en esta ocasión, así lo certifican. Su actitud proactiva frente a la enfermedad, sus propuestas terapéuticas y su servicio heroico fuera de sus establecimientos así lo indican. La Orden vive un momento de esplendor e ilusión renovada, desde la consagración en hospitalidad, una vez más los Hermanos están dispuesto a dar su vida. El compromiso es radical.

La epidemia de cólera solo en España causó 800.000 muertes en el siglo XIX. En 1884 el Dr. Ferrán fue comisionado por el Ayuntamiento de Barcelona para estudiar el cólera en Marsella, donde estaba causando estragos y amenazaba con propagarse, como pocos meses después así sucedería ${ }^{32}$.

La enfermedad se cebó especialmente en los establecimientos psiquiátricos de Ciempozuelos. Tanto el de varones regentado por los Hermanos de San Juan de Dios, como el de mujeres que asistían las Hermanas Hospitalarias del Sagrado Corazón de Jesús. Ambos establecimientos estaban dirigidos por el Padre Benito Menni. El alto grado de mortalidad hizo que su director Médico, el Dr. José Rodríguez González, intensificara la investigación y experimentación. En un breve espacio de tiempo, comenzó a introducir un remedio que contuviera el sufrimiento y la mortalidad de estos enfermos contagiados de cólera. Poco tiempo después de su aplicación, los resultados de éxito empezaron a sentirse con un alto porcentaje de curación. De la abrumadora cifra de un $75 \%$ pasaron a un $10 \%$. El método resultaba efectivo.

Entre tanto el Dr. Jaime Ferrán Clúa, en Barcelona, seguía profundizando en el hallazgo de una vacuna efectiva frente al contagio de esta enfermedad. Como afirma Mónica Arrizabalaga en su artículo "La odisea del español que creó la primera vacuna contra el cólera" publicado en Archivo ABC recientemente. Su convencimiento en los hallazgos que iba teniendo le llevaron incluso a inyectarse personalmente la vacuna. En 1885 la propagación de la enfermedad en toda España fue muy virulenta y sería en Valencia donde comenzó

32 BENAVIDES VÁZQUEZ, Francisco. La epidemia de cólera morbo de 1885 y la heroica actuación de la Orden Hospitalaria. En: Revista San Juan de Dios. Noviembre-diciembre 2020, nº 610, pp. 10-11. 
a aplicar su vacuna. En Alcira fueron vacunadas 11.000 personas de las que solo 24 fallecieron víctimas del cólera. De las 5.000 personas que quedaron sin vacunar, murieron 200. Así lo pone de manifiesto Arrizabalaga. Empezaba su gloria pero también su calvario. Las fulgurantes apoteosis quedaron interrumpidas por objeciones autorizadas y aun por violentas disputas, tal como señalaba J. Francos Rodríguez en "Blanco y Negro" en 1920.

Pero mientras la dinámica de la vacunación se hacía efectiva y se distribuía por el

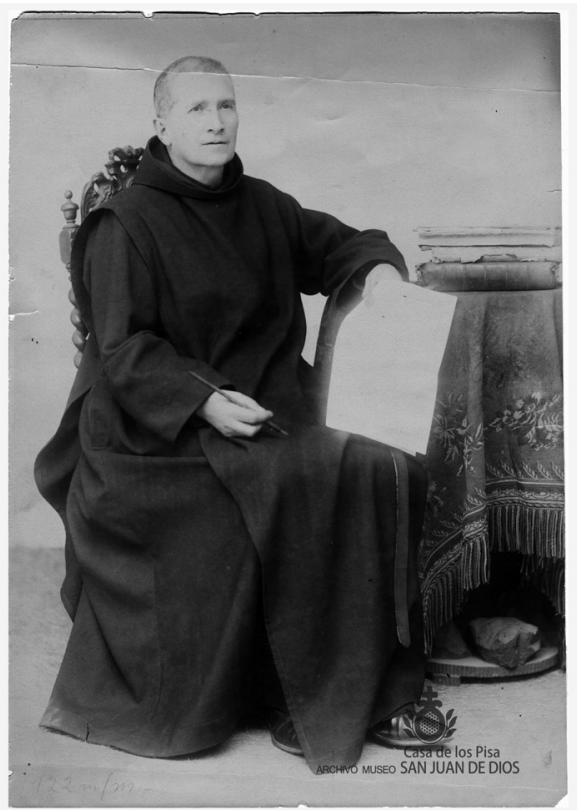
resto de la Península los casos de infectados se propagaban a gran velocidad.

El Hno. Benito Menni, convencido de la eficacia del remedio introducido por el Dr. D. José Rodríguez González, a base de inyecciones de extracto tebaico, es decir, de opio con el 10\% de morfina; fricciones de alcohol alcanforado en las extremidades superiores e inferiores, en el abdomen y en el estómago, seguidas de otras con ácido volátil de trementina en la espina dorsal, inició una decidida"Campaña anticolérica" ofreciendo sus servicios a numerosas poblaciones y ciudades de España. En todas con un gran éxito de curación, aunque también con la pérdida de algunos de los Hermanos enviados a las mismas. Entre las víctimas de la Orden que tenemos que registrar se encuentran: Fray Francisco Sáez de Gordoa en Granada; Fray Lucas Rafael Vázquez Montes en Santa Eulalia (Teruel); Fray Casimiro Evaristo LópezVillaseca en Yunquera (Málaga) ${ }^{33}$.

33 CIUDAD GÓMEZ, Juan, O.H. Necrologio de la Orden Hospitalaria. Actualizado por MUÑOZ MARTÍNEZ, José Luis, O.H. Granada: Archivo - Museo San Juan de Dios"Casa de los Pisa", 2021. 



El impulso de generosidad y entrega con el que respondieron los Hermanos a la invitación de fray Benito Menni (hoy San Benito Menni) para esta noble tarea hospi- talaria, lo describe el mismo Benito Menni en una de sus cartas:

"Entonces reuní a la Comunidad [de Ciempozuelos] y le dije que había que ir fuera, a diversos lugares, para asistir a los coléricos, todos se me ofrecieron con el mayor entusiasmo, hasta desear dar la vida para salvar al prójimo y a considerar como privilegiados a los que le tocase en suerte. Yo estaba muy impresionado porque los mandaba a un peligro de muerte muy evidente. Deseando probarlos una vez más con la piedra del símil, les dije:“ ¿Hijos míos, sabéis bien a donde os mando? Os mando a morir. ¿Os sentís con fuerza? ¿Estáis dispuestos a dar la vida por los apestados? Todos, con ánimo resuelto, me contestaron que sí lo estaban, con la gracia de Dios. Entre otros, fray Lucas, el más joven, con angélica alegría, me dijo: “'Ojalá, Rdo. Padre, tuviésemos tanta suerte”. A tal exclamación, no pude sino sentir un estremecimiento de conmoción. Lo abracé y le di la bendición, separándome luego de él hasta la eternidad: efectivamente, murió mártir de su amor al prójimo"34

La prensa de aquel tiempo, así como personalidades y autoridades civiles y eclesiásticas, tuvieron expresiones y manifestaciones, incluso oficiales, de vivo aprecio y alto elogio por esta labor asistencial prestada por los Hermanos con tanta abnegación y utilidad pública ${ }^{35}$. [Ver anexo 1]

34 LIZASO BERRUETE, Félix. Perfil juandediano del Beato Benito Menni (463 cartas). Granada: Archivo Interprovincial, 1985.

35 BENAVIDES VÁZQUEZ, Francisco y LÓPEZ-ÁVILA, Ma Begoña. La aportación terapéutica y asistencial de la Orden Hospitalaria frente a la epidemia de cólera morbo en 1885 en España. Colección epistolar. En: Archivo Hospitalario. Revista de Historia de la Orden Hospitalaria de San Juan de Dios. Granada: Archivo-Museo San Juan de Dios “Casa de los Pisa”, 2020, n 18, pp. 19-61. 
La población de Ciempozuelos sería la primera en beneficiarse de la aplicación de este tratamiento, junto a Chinchón, Aranjuez, Colmenar de Oreja...la fama del remedio y, la excelencia en el cuidado pronto supuso la petición de asistencia por alcaldes de otros ayuntamientos: Teruel, Guadalajara, Málaga... Así el de Villarejo de Salvanés (Madrid) en agosto de 1885 se dirigía al P. Benito Menni en estos términos:

"Invadida esta población por el cólera-morbo, desde hace días, se halla afligido este vecindario por no contar en primer término con los auxilios materiales necesarios [...] Nos consta que la más pequeña indicación es atendida por Vd. para llevar con sus Hermanos los consuelos y auxilios necesarios a las poblaciones epidemiadas [...] le suplicamos mande inmediatamente a esta Villa cuatro Hermanos".

Ante tanta demanda de petición de ayuda de las diferentes autoridades locales, los Hermanos se vieron desbordados. Pero no renunciando a divulgar el remedio hasta el más recóndito punto de España, el Padre Menni ideo la manera de enviar la fórmula de la medicina y la manera de su aplicación a aquellos pueblos donde los Hermanos no podían hacerse presentes [Anexo 2]. Así lo recuerda el Gobernador de Teruel el 20 de agosto de 1885.

“... de haber recibido un impreso de Don José Rodríguez González, que como médico titular de Ciempozuelos y del Manicomio de aquella población ha dado a la imprenta, y en el cual se manifiesta los adelantos obtenidos por dicho Señor González en el tratamiento por él introducido para la curación de los enfermos coléricos en aquella localidad, habiendo alcanzado un éxito donde la ciencia no había podido llegar hasta el día".

No solo la medicina ideada por el Dr. Rodríguez aliviaba el sufrimiento de los ciudadanos, la presencia de los Hermanos y sus atenciones también a ello contribuían. El Alcalde de Visiedo (Teruel) en una misiva dirigida al Hno. Benito Menni refería:

“... los Hermanos aquí enviados han sido distinguidos por su cariño y acertado comportamiento con los enfermos sin distinción de clases, prodigándoles toda clase de auxilios, tanto espirituales como corporales, actuando como expertos practicantes en la medicación del cólera y aún de cualquier otra dolencia..." 


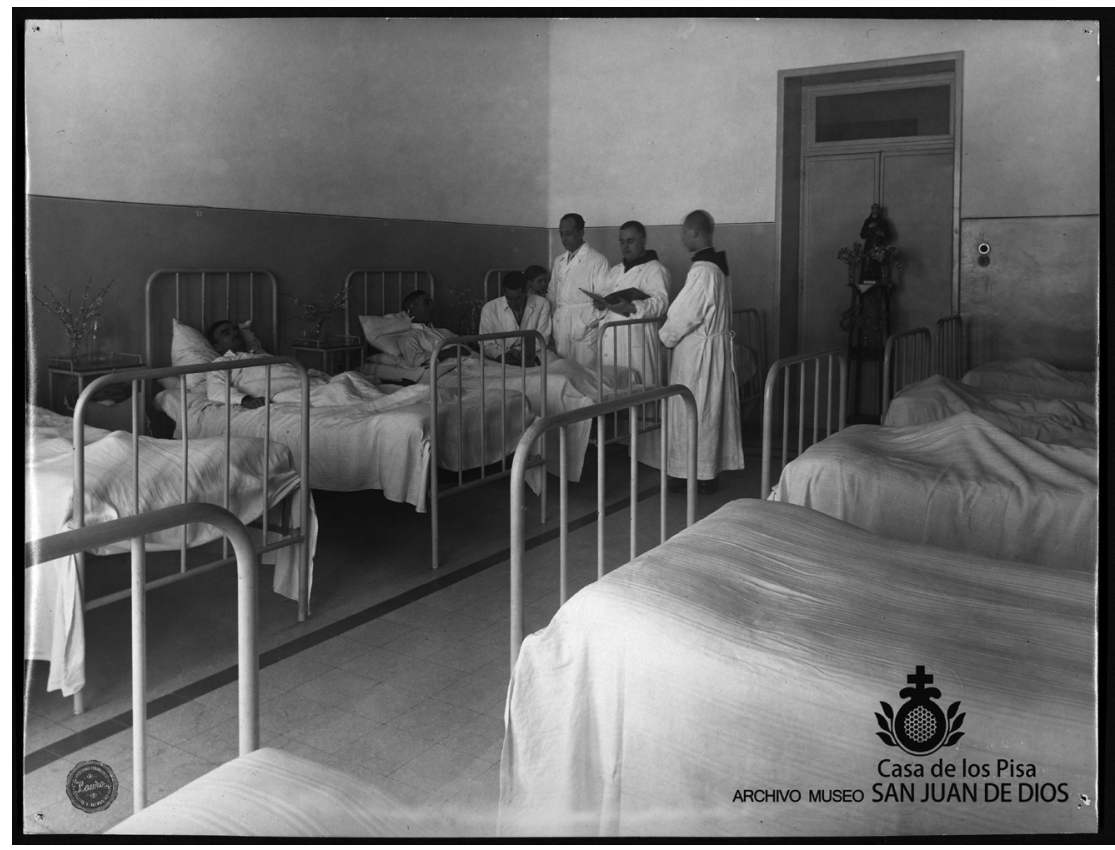

Granada sería otra de las ciudades a las que llegó la "campaña anticolérica" desplegada por Menni, no exenta de recelos y enfrentamientos con las autoridades sanitarias de la ciudad. El testimonio autógrafo del Hno. Joaquín Estruch (Superior de Granada) recogido por él mismo pasados los años nos dan buena cuenta de ello:

“... habiendo prestado mis servicios en la Villa de Aranjuez junto a la brigada de Hermanos allí enviados, hube de regresar nuevamente a Granada llevando conmigo un bote de extracto-tebaico".

Después de permanecer durante cuatro días en el lazareto de Granada como medida de prevención al proceder de un lugar altamente infectado, regresó al hospital de la Orden y se puso de acuerdo con el médico del establecimiento por si se presentaba algún caso de cólera estar dispuesto a combatirle. “No tardó en presentarse el cruel azote siendo el mes de junio cuando un día apareció el citado médico - D. Manuel de Vázquez - y le dijo al Superior haber descubierto un caso de cólera, siendo de notar que este fue el primero que se registró en Granada. Al momento se personaron en la casa del atacado y, al dejarla, lo hicieron con gran satisfacción por advertirse a la primera 
inyección que se le puso una notable mejoría. Aquel día con ocasión de hallarse juntos el Superior y el Médico, (Struch y Vázquez) en casa del último, recibieron la visita de dos Facultativos que iban comisionados por el Ayuntamiento, recriminaron al médico y Superior del Hospital porque al decir de ellos habían sembrado la alarma en Granada sin motivo fundamentado, siendo en vano todo el trabajo que se tomaron para convencerlos que la capital está invadida de cólera, por fin

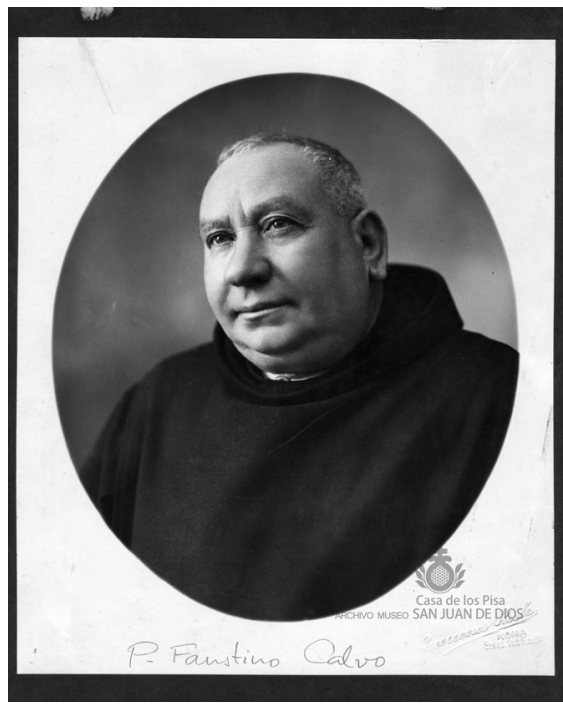
se dirigieron en el mismo coche que los había llevado a la habitación del enfermo, donde los médicos del Ayuntamiento después de un detenido examen confirmaron la existencia de la epidemia en Granada.

A otras capitales como Sevilla y Barcelona también ofreció sus servicios el Hno. Benito Menni. Ambas rechazaron la ayuda y la aplicación del tratamiento que tantas vidas había salvado por diferentes rincones del país. Mientras tanto, el Dr. Ferrán seguía tratando de argumentar la eficacia de su vacuna. Sus colegas catalanes le acusaron de falsario y le destituyeron de su plaza de director del Laboratorio Municipal de Barcelona. En 1907 le fue otorgado el premio Breant considerándolo el jurado como el verdadero iniciador de la inmunización contra el cólera. Mientras tanto y a fecha de hoy 2020, pocos conocen el beneficio que propició a los enfermos de cólera el remedio del Dr. Rodríguez y la aplicación que de él hicieron un abultado número de Hermanos de San Juan de Dios. Muchos de ellos habiendo dado su vida en esta acción humanitaria.

\section{EPIDEMIAS DE VIRUELA Y CÓLERA EN CIEMPUELOS Y VIZCAYA RESPECTIVAMENTE \{1890-1 / 1893\}}

El siglo buscaba su final, pero no faltaron calamidades. La viruela azotó fuertemente a la población de Ciempozuelos, donde sabemos 
ya que estaba instalado un centro psiquiátrico de San Juan de Dios, muy consolidado ya por esta fecha, junto a otras poblaciones de la provincia de Madrid. Las autoridades sanitarias solicitaron religiosos de San Juan de Dios para prestar sus servicios en hospitales públicos y en domicilios particulares.

El cólera seguía manifestándose en el norte de España, especialmente en la provincia deVizcaya, y una vez más el Superior Provincial de la Orden, fray Benito Menni, ofreció a las autoridades sanitarias el servicio de los Hermanos y Hermanas Hospitalarias. Seis religiosos formados en enfermería fueron destinados para aquella misión. Del decidido y abnegado grupo formaba parte el Hno. Faustino Calvo, que años más tarde sería elegido Superior General de la Orden.

\subsection{Amenazas que parecían lejanas:}

SIDA / Ébola

\section{LA PROPAGACIÓN DEL SÍNDROME DE \\ INMUNODEFICIENCIA ADQUIRIDA (VIH/SIDA) $\{1980$ - 2000\}}

Una de las enfermedades que más protagonismo cobró durante las décadas de 1980-2000 fue el Síndrome de Inmunodeficiencia Adquirida (SIDA). Desde 1979, muchos especialistas provenientes de las más distinguidas universidades vaticinaron que, en pocos años, el SIDA se convertiría en una pandemia mundial que sesgaría la vida de millones de personas.Y lo cierto es que en poco o en nada se equivocaron, pues en 1981 se recibió la noticia de las cinco primeras afecciones delVirus de Inmunodeficiencia Humana (VIH) en Kaposi, California. Para el caso de España su llegada tampoco habría de hacerse esperar, ya que el primer caso documentado fue detectado en Barcelona en diciembre de 1981. El SIDA había de ser considerado como una enfermedad humana que merecía los mismos cuidados y atenciones que cualquiera otra. Con fecha 15 de septiembre de 1986, se habían detectado nada menos que 24.430 casos de SIDA en EE.UU. En las inmediaciones de alguna diócesis, recordaba que se habían producido 430 afecciones diagnosticadas. De ellas, 254 personas habían perdido la vida, lo que suponía una tasa de mortalidad de casi un 60\% de los pacientes. En cuanto a nuestras fronteras, la Comisión Permanente de la Conferencia Episcopal Española (CEE), pocos meses después, emitía una nota pastoral sobre algunas consideraciones respecto a dicha enfermedad. En ella, expresaba que las instituciones religiosas 
prestarían la misma atención a los afectados por este mal que a cualquier otro enfermo. Por otra parte, demandaba urgentemente a los Institutos religiosos de corte sanitario la creación de servicios especializados en esta tipología asistencial. La proliferación de este mal hizo que la Organización Mundial de la Salud (OMS), celebrara una gran asamblea en Londres, durante los días 26 y 28 de enero de 1988, para dialogar y analizar en detalle sobre aquella nueva afección. A ella acudieron más de 700 profesionales de 150 naciones, y una representación de la Comisión Pontificia para la Pastoral de los Asuntos Sanitarios $^{36}$. Meses después, y ante la expansión incontrolada de aquella inmunodeficiencia, el Ministerio de Justicia propuso que la Orden Hospitalaria destinase algunos de sus centros a la atención de enfermos terminales de SIDA. Durante los días 13 al 15 de noviembre de 1989, tuvo lugar la IV Conferencia Internacional sobre el SIDA, promovida y coordinada por el Pontificio Consejo para la Pastoral de Agentes Sanitarios, en el Aula Grande del Sínodo del Vaticano. En total, más de 1.300 estudiosos de 84 nacionalidades se dieron cita en la Ciudad Eterna para estudiar cómo erradicar aquella enfermedad. Sin embargo, y a pesar de todos los esfuerzos, en pocos años, el virus saltó y arraigó en suelo africano, mostrando en dicho continente la peor de sus caras, pues, a todos los efectos nocivos de dicha enfermedad, habíamos de sumar la condición de subdesarrollo que se vivía en aquellas latitudes. Estas particulares condiciones hicieron que los seropositivos aumentaran de forma exponencial en África en los años siguientes. Según los datos manejados por la OMS, en 1992 el SIDA ya había acabado con la vida de más de un millón de africanos. Pero no solo eso, las cifras aún habían de ser más dramáticas, como de hecho lo fueron, ya que en aquel continente residían nada menos que seis de los diez millones de afectados en todo el mundo por dicho mal. Por ofrecer algunas cifras, hemos de apuntar, según nos recuerda el Registro Nacional de Sida, que desde los primeros casos de 1981 a los recuentos de finales de 1992 se habían diagnosticado 15.678 casos de contagio delVIH en España. Liderando el ranking se situaba la provincia de Cataluña con 4.059 afecciones, alcanzando un pico de 951 infecciones en los primeros años de la década de los 90; seguida de la

36 GARCÍA RÍOS, José María. San Juan de Dios en España (1950-2020). Una respuesta desde la hospitalidad. Granada: Archivo-Museo San Juan de Dios "Casa de los Pisa", 2021. Colección Temas Históricos O.H. 
Comunidad de Madrid con 3.648, Andalucía con 1.679, el País Vasco con 1.488 y la Comunidad Valencia con 1.260, lógicamente las áreas geográficas con mayor densidad poblacional del país. Según las cifras del Instituto Nacional de Estadística, a mediados de la década de los 90, el SIDA era la principal causa de muerte entre la población española de los 25 a los 45 años, llegando a las 6.000 muertes anuales. De hecho, en aquella coyuntura, contraer el virus era casi la antesala de la muerte. Los Hermanos de San Juan de Dios siguieron empeñados en ofrecer cobertura y mejorar las condiciones de vida de los afectados por elVIH (Virus de la Inmunodeficiencia Humana). La Provincia Bética colaboraba desde mediados de 1992 junto a Cáritas Diocesana y las Hijas de la Caridad en la Casa de Acogida"Colinchet" de Málaga, destinada a recoger y socorrer a los afectados de SIDA. Las herederas de san Vicente de Paúl se encargaban de los pacientes durante el día y los Hermanos de San Juan de Dios hacían lo propio durante la noche. Además de dicho centro, la mencionada demarcación religiosa, a través del Centro Asistencial San Juan de Dios de Málaga, proyectó el establecimiento de un piso protegido en la capital de la Costa del Sol para enfermos de SIDA y personas afectadas por el problema de la drogadicción. El Consejo Provincial de los Hermanos de San Juan de Dios en la provincia de Aragón, por su parte, también padecía con gran angustia la proliferación de los afectados por SIDA. No hay más que echar un vistazo a los esfuerzos realizados desde 1992 en la unidad especializada del Albergue Sant Joan de Déu de Barcelona. Así las cosas, la preocupación sobre el Síndrome de Inmunodeficiencia Adquirida volvía a estar sobre la mesa, una vez más, en el Simposium Nacional sobre Drogodependencias y Sida a las puertas del siglo XXI, celebrado en el Centro Asistencial San Juan de Dios de Palencia, durante los días 27 y 28 de febrero de 1998, como homenaje al primer centenario del nacimiento de san Ricardo Pampuri. El virus no desaparecía sino que tendía a hacerse crónico, pero, en cualquier caso, reducía las posibilidades de muerte de los afectados a corto o medio plazo. Una noticia más que celebrada por los profesionales de la sanidad, los enfermos y la población mundial. De hecho, según los datos de la Federación Europea de la Industria Farmacéutica, la tasa de mortalidad de pacientes afectados por el SIDA en España, entre 1995 y 2003 , se redujo en un $92 \%$, alargando la esperanza de vida de los mismos en unos diez años. Los usuarios de Sant Joan de Déu Serveis Socials de Barcelona, a pesar de los complicados cuadros médicos que 
presentaban, también lograban reducir su tasa de mortalidad en un $46 \%$, entre 1997 y 2002. Sin embargo, y a pesar de todos los esfuerzos, el estudio realizado por la Agencia de la Organización de las Naciones Unidas para la lucha contra el SIDA (ONUSIDA), estimaba que en 2001 aún había cinco millones de personas afectadas por el virus en todo el mundo. Ello suponía un promedio de infección de 14.000 personas al día, en su gran mayoría, localizadas en países en vías de desarrollo. El propio Juan Pablo II, en una de sus últimas intervenciones públicas, con ocasión de la XIII Jornada Mundial del Enfermo, celebrada el 11 de febrero de 2005 en Camerún, aprovechaba para insistir, una vez más, en la lucha conjunta de todos frente al SIDA. He aquí las palabras del Sumo Pontífice: «Todos deben sentirse implicados en la lucha contra el SIDA. Sobre este tema, compete a los gobernantes y a las autoridades civiles proporcionar informaciones claras y concretas al servicio de los ciudadanos, así como también dedicar recursos suficientes a la educación de los jóvenes y al cuidado de la salud. Animo a los organismos internacionales para que promuevan en este campo iniciativas que, inspirándose en la sabiduría y la solidaridad, estén encaminadas siempre a defender la dignidad humana y a tutelar el derecho inviolable a la vida».

\section{EPIDEMIA DE ÉBOLA, CONSCIENTES DE LA FRAGILIDAD, REPERCUSIÓN SOCIAL \{2014\}}

Han pasado los años, muchos desde los que no hemos sentido como sociedad española amenazados por una enfermedad de fuerte trasmisión y contagio y que comprometa nuestra integridad. Pero nuestros hermanos de los países en vías de desarrollo no gozaban de esa seguridad. En el día a día, la enfermedad y la carencia de remedio convive estrechamente con ellos. Podemos decir que estábamos "confiados" o entretenidos en otras cuestiones, creyéndonos a salvo. Los Hermanos de San Juan de Dios, nativos y misioneros en estos países más desfavorecidos, nos iban a despertar de un largo letargo. La enfermedad conocida como ébola, ni habíamos oído hablar de ella.

En esta ocasión, por ser más reciente y tener una mayor sensibilidad y medios podemos hacer un relato más detallado del servicio que la Orden Hospitalaria ha prestado en la lucha contra esta enfermedad. Y como siempre, con la pérdida de números miembros de la Orden, consagrados y colaboradores comprometidos que estando al servicio del enfermo, entregaron su vida. 
Antes que nada, conviene establecer algunas consideraciones previas al nacimiento y proliferación de dicha enfermedad. En este sentido, los primeros testimonios documentados del virus databan de 1976 en los alrededores de la cuenca del río Ébola, situado en la República Democrática del Congo. Circunstancia por la que la epidemia terminó adoptando el mencionado sobrenombre.

Con el paso de los años, y de manera silenciosa, al menos en lo que al mundo occidental se refiere, el foco infeccioso se fue extendiendo hacia Sudán del Sur, Uganda y el norte de Angola. Penetrando, sin ninguna resistencia, en los países del flanco oeste del continente africano. ${ }^{37}$

Según la información emanada de la Curia General de la Orden, algunos de los síntomas de la inoculación del virus se revelaban a través de fiebres repentinas, debilidad corporal, dolor muscular, migrañas y vértigos o repentinos problemas de garganta. Manifestaciones que podían aparecer entre los dos y los veintiún días después del contagio. Con el paso del tiempo, y una vez implantado el brote vírico en el organismo, estos cuadros sintomatológicos solían derivar en fuertes diarreas, vómitos, alteraciones de las funciones renal y hepática, hemorragias internas y externas, etc.

Unos síntomas verdaderamente complejos para los infectados que aún habrían de tornarse más dramáticos, ya que la epidemia no disponía de ningún retroviral o antídoto, dependiendo, en gran medida, de la precocidad en que fuese detectada y de la respuesta que pudiese ofrecer el sistema inmunológico..$^{38}$

Por ello, no es de extrañar que, debido a los progresivos contagios de Ébola que se estaban produciendo en la parte más occidental de África, concretamente en los países de Sierra Leona, Liberia, Nigeria, Senegal y Guinea Conakry, el Hno. Jesús Etayo Arrondo, superior general de la Orden, pusiese en marcha, a la altura de julio de 2014, la campaña“Paremos el Ébola en África del Oeste", organizada desde la Fundación de la Orden Hospitalaria: Juan Ciudad ONGD, en coordinación con la Curia General, donde participaron todas las Provincias de la Orden y otras tantas organizaciones eclesiales.

37 GARCÍA RÍOS, José María. San Juan de Dios en España (1950-2020). Una respuesta desde la hospitalidad. Granada: Archivo-Museo San Juan de Dios "Casa de los Pisa", 2021. Colección Temas Históricos O.H.

38 Información y Noticias de los Hermanos de San Juan de Dios, n 238, julio-agosto de 2014, p. 8 . 

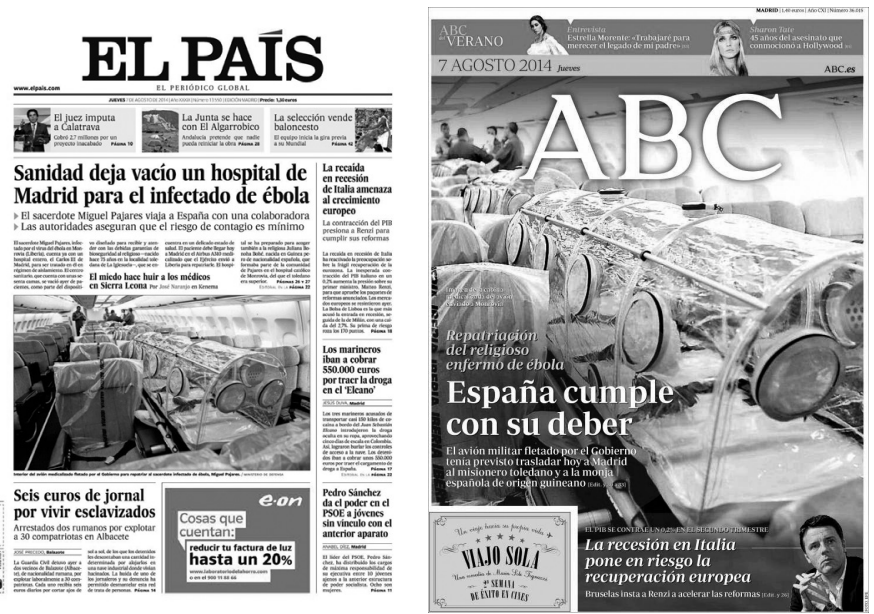

De hecho, la Organización Mundial de la Salud (OMS) estimaba que, a mediados de 2014, el brote vírico había causado la muerte a más de 4.500 personas e infectado a casi 9.500. Y, lo más grave, es que, por el momento, no se disponía de antivirales o tratamientos específicos contra la epidemia. ${ }^{39}$

Situación que habría de recrudecerse aún más en los meses siguientes. Evidentemente, nos referimos al contagio de la enfermedad por parte de algunos miembros de la Familia Hospitalaria al asistir a los centenares de enfermos que acudían diariamente a los hospitales de Liberia y Sierra Leona.

De este modo, se producía la inoculación del virus del Ébola en los Hermanos Patrick Nshamdze, George Combey y en la Hermana Chantal Pascaline. No obstante, y a pesar de la gravedad de la situación, las primeras averiguaciones médicas que se hicieron sobre estos religiosos resultaron negativas al contagio de la enfermedad. Un hecho, que se tornaría crucial para el futuro de otros tantos miembros de la Institución Hospitalaria.

Pese a lo expuesto, los esfuerzos por mejorar la salud de estos religiosos y de otros tantos afectados resultaron amargamente infructuosos. Así las cosas, el 2 de agosto hemos de anotar el fallecimiento del hospitalario camerunés Patrick Nshamdze. Tan sólo unos

\footnotetext{
39 Hermanos Hospitalarios. Boletín Informativo de la Provincia de Castilla, $2^{\mathrm{a}}$ época, $\mathrm{n}^{\mathrm{O}}$ 35, octubre-noviembre de 2014, p. 199.
} 
días después, el 9 de agosto se producía la muerte de la religiosa congoleña de las Misioneras de la Inmaculada Concepción Chantal Pascaline y el 11 de agosto perecía el hospitalario ghanés George Combey. Otra pérdida igualmente sentida entre los sanitarios que velaban por la salud de los enfermos fue la del Dr. Sheik Umar Khan, un destacado médico del Hospital de San Juan de Dios, que dio su vida por erradicar el virus en Sierra Leona.

Mientras tanto, conviene recordar que en aquellas latitudes ejercían su misión varios religiosos y colaboradores españoles. Una circunstancia que provocó que la Orden Hospitalaria de San Juan de Dios iniciase los contactos con el Gobierno de España para intentar la repatriación de los misioneros que llevaban a cabo su apostolado en Liberia y Sierra Leona. Sin embargo, y como rápidamente podemos entrever, no se trataba de un caso trivial y baladí, pues debido a la peligrosidad de contagio de dicha enfermedad fue necesario solicitar el permiso de hasta tres ministerios: Defensa, Asuntos Exteriores y Cooperación y Sanidad, Servicios Sociales e Igualdad. ${ }^{40}$

Una vez obtenido el consentimiento del Estado, el Hno. Miguel Pajares Martín y la Hna. Juliana Bonoha Bohé eran repatriados a España desde Liberia, en un Airbus A-310 del Ejército del Aire medicalizado. Su destino era la sexta planta del Hospital Carlos III de Madrid, un espacio previamente habilitado para la llegada de dichos religiosos, en parte, gracias a los esfuerzos del Comité de crisis de la Institución Hospitalaria y del Hermano Miguel ÁngelVarona Alonso, presidente de la Fundación Juan Ciudad y Superior Provincial de la Orden en la Provincia de Castilla.

El desembarco de los religiosos en España, en absoluto, estuvo exento de crítica, en medio de una expectación mediática; salpicando hojas y hojas de tinta de los principales diarios y copando las retransmisiones de los medios de comunicación nacionales. Una preocupación social, en cierto modo, lógica, pues durante su misión los consagrados habían adquirido el virus y podían suponer una amenaza para otros pacientes españoles. El miedo se instalaba en la sociedad española.

Sin embargo, desproporcionada y deshonesta en lo que se refiere a la ignorancia e inopia de algunas argumentaciones periodísticas,

40 Hermanos Hospitalarios. Boletín Informativo de la Provincia de Castilla, $2^{\mathrm{a}}$ época, $\mathrm{n}^{\circ}$ 35, octubre-noviembre de 2014. 

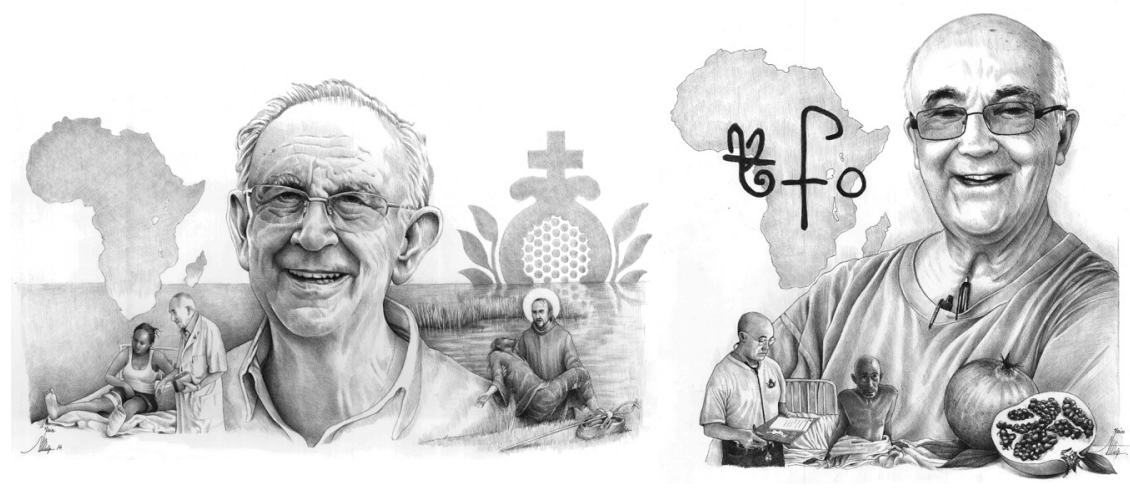

llegando a cuestionar hasta la propia vocación de los misioneros al "no querer morir entre los suyos". ${ }^{41}$

Por lo que se refiere al Hno. Miguel Pajares Martín, según su círculo más inmediato, contrajo la epidemia al asistir en su enfermedad al Hno. Patrick. Anteriormente hicimos mención al resultado de los primeros test efectuados al religioso camerunés, los cuales, al dar negativo, provocaron cierta relajación en todo el equipo de cuidadores del centro. Un error capital que a la postre resultaría definitivo, si nos ceñimos a una metodología estrictamente médica, pero totalmente asimilado dentro del carisma juandediano, abogando siempre por la cercanía al enfermo y necesitado, a pesar de las contraindicaciones que podía conllevar. ${ }^{42}$ Eso, al menos, reflejaba uno de los últimos correos del religioso hospitalario:

41 Para esta última cuestión, interesa la reflexión de la editorial de la revista San Juan de Dios. Cfr.: San Juan de Dios, no 573, septiembre-octubre de 2014, p. 4. Por otro lado, tenemos que señalar el revuelo mediático que supuso el contagio del virus por parte de doña María Teresa Romero Ramos, auxiliar de Enfermería del Hospital Carlos III de Madrid, con el consiguiente sacrificio de Excálibur, su perro, levantando diversas movilizaciones sociales a este respecto. En este sentido, puede resultar significativa la información proporcionada por algunos medios de comunicación, como por ejemplo: https://elpais.com/tag/teresa_romero_ramos/a; https://www. elespanol.com/reportajes/20190106/teresa-romero-contagiada-refugiada-farmacia-no-pacientes/365993406_3.html o las aportaciones contenidas en:https:// www.elperiodico.com/es/sociedad/20170426/muerte-excalibur-perro-ebola-fueinevitable-5998769 Consultados el 17 de octubre de 2019.

42 De hecho, la Carta de Identidad de la Orden abogaba por convertir en una prioridad absoluta la asistencia a pacientes que presentaban enfermedades contagiosas, y el Ébola ciertamente lo era. Cfr.: Orden Hospitalaria de San Juan de Dios, La Carta de Identidad de la Orden..., op. cit., p. 123. 
«Tenemos muchos problemas. Han fallecido dos personas y trece se niegan a venir a trabajar, quieren quedarse en cuarentena. Yo he ido cada día y he saludado a todos. Me meten miedo, la muerte ronda. Se sospecha de algún caso más de Ébola. Esperamos resultados. Es penoso, pero hay que estar. Lo comparo a la guerra, aunque esto es más peligroso. El enemigo en casa».43

Sea como fuere, el Hno. Miguel Pajares Martín regresaba a España el 7 de agosto, junto a la Hermana Juliana. A pesar de la inoculación del virus y de las fuertes medidas de prevención suministradas, el estado de salud del sacerdote hospitalario se mantenía estable. Sin embargo, a los cinco días de ser repatriado, y de las innovaciones farmacológicas administradas, todos los esfuerzos para salvar su vida resultaron yermos, falleciendo en la madrugada del 12 de agosto de $2014^{44}$

Casi sin tiempo para digerir tan dolorosa pérdida, la Orden Hospitalaria habría de hacer frente a la delicada situación de otro de sus religiosos. En esta ocasión, se trataba del Hermano Manuel Alfonso García Viejo, director médico del St. John of God's Catholic Hospital de Lunsar, cuyo diagnóstico de contagio por Ébola se confirmaba el 20 de septiembre. Rápidamente, la Orden Hospitalaria dispuso todos los trámites necesarios para la repatriación del religioso, produciéndose su llegada el 22 del mismo mes al Hospital Carlos III de Madrid, procedente de Sierra Leona. Aunque al inicio, su estado de salud era grave, lo cierto es que mejoró levemente al día siguiente, dando esperanza y aliento a toda la Familia Hospitalaria [Anexo 3].

En ese ínterin, los facultativos del centro médico madrileño, auspiciados por el Ministerio de Sanidad, intentaron administrarle Zmapp, un tratamiento que aún se encontraba en fase experimental para la OMS, pero que había arrojado resultados positivos en algunos pacientes. No obstante, precisamente por su condición de "prueba no testada", no se pudo hallar ningún fármaco disponible en aquel momento. Ante la inexistencia del anterior, se le intentó administrar el suero de un paciente alemán que se había repuesto al virus, sin embargo aquella muestra contenía hepatitis $\mathrm{C}$, un riesgo demasiado elevado para el delicado estado de salud del Hno. García

43 Hermanos Hospitalarios. Boletín Informativo de la Provincia de Castilla, $2^{\mathrm{a}}$ época, $\mathrm{n}^{\circ}$ 35, octubre-noviembre de 2014, p. 237.

44 Hermanos Hospitalarios. Boletín Informativo de la Provincia de Castilla, $2^{\mathrm{a}}$ época, $\mathrm{n}^{\mathrm{o}}$ 35, octubre-noviembre de 2014, p. 234. 
Viejo, por lo que los especialistas del Carlos III terminaron descartando aquella vía. Unos días más tarde, volvía a recaer súbitamente de sus dolencias, provocando el fallecimiento del misionero la tarde del 25 de septiembre.

Por si fuera poco el dolor de la Familia Hospitalaria, aún habría que añadir el fallecimiento de trece colaboradores trabajadores de la Orden, además de otros tantos pacientes de los centros médicos juandedianos. ${ }^{45}$ Dramáticos sucesos, sin duda, que acabaron provocando el cierre el 1 de agosto del St. Joseph's Catholic Hospital de Monrovia y su posterior desinfección; días después el establecimiento médico de Lunsar corría la misma suerte. ${ }^{46}$

La situación de emergencia que vivían los centros de Liberia y Sierra Leona provocó que en la segunda mitad del año 2014 el Ministerio de Sanidad y la Agencia Española de Cooperación Internacional de Desarrollo (AECID), a través de Juan Ciudad ONGD, destinase once toneladas de materiales sanitarios para contribuir a la prevención y protección de la epidemia del Ébola [Anexo 4]. Del mismo modo, don Roberto Lorenzo Alberti, coordinador de proyectos de cooperación de Juan Ciudad ONGD, se ofrecía para estudiar la viabilidad de la vuelta al funcionamiento de los hospitales africanos. Se trataba, pues, de una ayuda absolutamente indispensable para proceder a la reapertura de los establecimientos médicos juandedianos.

Por su parte, el equipo de coordinación de Saint John of God Fundraising Alliance, con el Hermano Moisés Martín Boscá, director de la Oficina de Misiones y Cooperación Internacional, a la cabeza, se daba cita en la Curia Provincial de Aragón el 22 de octubre de 2014 para debatir en profundidad la situación de los centros hospitalarios afectados por los brotes de Ébola y prever su próxima reapertura. ${ }^{47}$

Pese a que las cifras ofrecidas por la OMS alcanzaban ya los 15.350 casos confirmados de Ébola y unas 5.500 muertes (310 sanitarios, aproximadamente), el 24 de noviembre de 2014, tras cumplir con

45 He aquí el nombre de los trece colaboradores fallecidos en Liberia y Sierra Leona: Laurene Togba, Layson Wilson, Tetee Dogba, Dominic Wesseh, Richard Kollie, Isata Kanu, Mohamed Kuyateh, Fatmata Bangura, Michaella Conteh, Mamusu Kamara, Umar Kanu, Aminata Kamara y Salamatu Sesay.

46 Hermanos Hospitalarios. Boletín Informativo de la Provincia de Castilla, $2^{\mathrm{a}}$ época, $\mathrm{n}^{\mathrm{o}}$ 35, octubre-noviembre de 2014, p. 199.

47 Información y Noticias de los Hermanos de San Juan de Dios, $n^{\circ} 240$, noviembrediciembre de 2014, pp. 8-9. 
los protocolos de seguridad y la supervisión del Comité Internacional de Cruz Roja, el St. Joseph's Catholic Hospital de Monrovia reabría sus puertas con el objetivo expreso de atender al área de maternidad de la capital del país. En ningún caso, como rápidamente podemos entrever, habría de cubrir los procesos relacionados con el Ébola, si bien contaba con una Unidad de Espera para aislar y tener en cuarentena, durante 48 horas, a aquellos pacientes que presentaran los síntomas médicos prototípicos de la epidemia. He aquí un extracto de las palabras del Hno. José María Viadero Torre, director de Juan Ciudad ONGD, el día de la reapertura:

«Esta reapertura significa abrir una puerta a la esperanza en Liberia, ya que ofrecerá atención en maternidad, un área que está muy desatendida pero que es prioritaria, y se suma a los esfuerzos que se están haciendo por mejorar la salud de la población en medio de la epidemia de Ébola». ${ }^{48}$

Durante los actos organizados en la reapertura del St. Joseph's Catholic Hospital de Monrovia se encendieron velas en conmemoración de todos los fallecidos por Ébola que trabajaban en el centro médico de Liberia. Un hito que no quiso pasar por alto el máximo responsable de la archidiócesis de Monrovia, monseñor Lewis Zeigler, quien tuvo un especial recuerdo para los fallecidos, admirando: «su coraje, compromiso y sacrificio para ayudar a otras personas». ${ }^{49}$

Por el contrario, la reapertura del St. John of God's Catholic Hospital de Lunsar hubo de retrasarse hasta el día 6 de enero de 2015, tras seis meses de hermetismo preventivo, gracias a la colaboración de diferentes instituciones y asociaciones, así nacionales como internacionales. Coincidiendo, además, con el retroceso de los contagios, el 2 de marzo de 2015, según informaba la Oficina de Misiones y Cooperación Internacional de la Curia General, se reanudaba también el devenir asistencial del St. John of God de Lungi en Sierra Leona, después un largo proceso de formación y prevención a los asistentes del mismo. Con la vuelta a la actividad de este establecimiento, la Orden volvía a disponer de operatividad en todos sus centros, tanto Sierra Leona como en Liberia.

48 Hermanos Hospitalarios. Boletín Informativo de la Provincia de Castilla, $2^{\mathrm{a}}$ época, $\mathrm{n}^{\circ}$ 36, diciembre de 2014, pp. 315-316.

49 Información y Noticias de los Hermanos de San Juan de Dios, $n^{\circ} 240$, noviembrediciembre de 2014, p. 18. 
Tal llegó a ser el nivel de implicación de los hospitalarios en este campo que, a finales de 2014, el presidente del Tribunal Constitucional de España, don Francisco Pérez de los Cobos, anunció que la XXIII edición del Premio Convivencia, otorgado por la Fundación Broseta, había de recaer en la Orden Hospitalaria de San Juan de Dios por su abnegada lucha contra el Ébola. Según sus palabras, se había inclinado por dicha opción entre más de 16 candidaturas porque: «merece el reconocimiento de la sociedad por el trabajo que la Orden está realizando en este campo». ${ }^{50}$

La pérdida de los religiosos, sin duda, supuso un amargo trago para la Orden Hospitalaria que tardó demasiado tiempo en cicatrizar, sin embargo, aquellos funestos sucesos sembraron un abonado legado humanitario, admiración y respeto, por unos hospitalarios que se caracterizaron por su entrega a los colectivos sociales menos favorecidos. Así, al menos, lo apuntaba el Superior General de la Orden en una entrevista concedida a la revista San Juan de Dios:

«A la Orden se la ha conocido mucho más y la gente ha tenido la oportunidad de acercarse más a san Juan de Dios [...] Lo que más valoro yo de todo esto es el ejemplo que nos han dado los Hermanos y colaboradores, la fuerte llamada que ha significado para nosotros el hecho de demostrar que dedicarse a los demás no es un discurso, sino que es una realidad que a veces se paga con la vida. Esto revaloriza mucho el sentido de la misión de la hospitalidad». ${ }^{51}$

Muestra de ello fueron los numerosos gestos de solidaridad proyectados en todos los centros de la Orden.

Del mismo modo, el 12 de septiembre de 2015 la Asociación Nacional de Guardias Civiles"Marqués de las Amarillas"también quiso tener un homenaje con los religiosos y colaboradores fallecidos a causa del Ébola. Para ello, se aprovechó la sala de usos múltiples de la localidad cántabra de Sarón, en cuya fachada el Hno. Juan José Ávila Ortega, como superior del Hospital de Santa Clotilde, descubrió una placa en reconocimiento al “Testimonio y compromiso con el pueblo de África durante la epidemia de Ébola".

Pese a haberse reducido en gran medida la letalidad de dicha epidemia, el informe de la Organización Mundial de la Salud de

\footnotetext{
50 Flash Informativo de la Provincia Bética, n 1.110, 23 de diciembre de 2014.

51 San Juan de Dios, nº 577, mayo-junio de 2015, p. 20.
} 
mediados de 2015 calculaba que el virus había acabado con la vida de 11.235 personas y contagiado a un total de 27.550. Unas estadísticas, desde luego, impactantes que hacen que pongamos aún más en valor el arrojo y hospitalidad mostrados por los miembros de la Familia Hospitalaria en los centros de Liberia y Sierra Leona, trabajando día a día en mejorar la situación de las personas asistidas.

Desde luego, el impacto social y la pérdida de 18 miembros de la Familia Hospitalaria motivaron que los Hermanos de San Juan de Dios fuesen reconocidos con diversos premios y condecoraciones por su entrega incondicional a las personas menos favorecidas. Entre ellos, podemos destacar los siguientes: III Edición Premios Nécora (Ayuntamiento de Noja, Cantabria); Premio Fundación del Año 2014 de la Sociedad Española del Dolor (Madrid); XXVII Edición del Premio Ideales del Año del Periódico Ideal (Granada); Premio Odontología Solidaria por la lucha contra el Ébola en Sierra Leona del Colegio de Odontólogos (Barcelona); Premio Mejor Labor Humanitaria 2014 de la Asociación Cultural Tertulia XV (Manzanares, Ciudad Real); XIII Premio Internacional a la Solidaridad del Gobierno de Navarra (Pamplona); Premio Tribuna Fórum en la categoría de "Medicina de Tribuna Fórum" (Tenerife); Premio Salud $A B C$, categoría Mejor Hospital del periódico ABC (Madrid); XXIII Premio Especial EDIMSA de Editores Médicos SL (Madrid); Premio Defensa de los Valores Humanos de la Fundación Social Universal (Córdoba); Premio Convivencia de la Fundación Manuel Broseta (Valencia); Premio Ciudadano Europeo (Madrid y Bruselas) ${ }^{52}$; el Grade of Knight Offical (Liberia); Premio a la Institución Sanitaria 2015 otorgado por el Instituto de Investigación y Desarrollo Social de Enfermedades Poco Frecuentes (INDEPF) (Campo de Criptana, Ciudad Real); Premio del Colegio Oficial de Enfermeros (Santa Cruz de Tenerife), XVII Premio Solidaridad (Burgos) o el XVII Premio Solidaridad (Burgos).

Del mismo modo, hemos de recordar que en diciembre de 2015 el Ministerio de Sanidad, Servicios Sociales e Igualdad, a través de don Alfonso Alonso Aranegui y de doña María Soraya Sáenz

52 Propuesto por el eurodiputado, don Gabriel Mato Adrover, en virtud del trabajo llevado a cabo por la organización de los derechos humanos y la asistencia a las personas que más lo necesitan. Concedido el 25 de febrero de 2015 en Bruselas. Interesa: San Juan de Dios, n 575, enero-febrero de 2015, p. 6 y San Juan de Dios, $\mathrm{n}^{\mathrm{o}} 576$, marzo-abril de 2015, p. 30 y Flash Informativo de la Provincia Bética, $\mathrm{n}^{\circ}$ 1.107, 24 de noviembre de 2014. 
de Santamaría Antón, vicepresidenta del Gobierno, entregaba al Hno. Miguel Ángel Varona Alonso, presidente de la Fundación Juan Ciudad y superior provincial de Castilla, la cruz de la Orden Civil de Sanidad concedida a los Hermanos Miguel Pajares Martín y Manuel Alfonso García Viejo a título póstumo, por los méritos sobradamente demostrados a lo largo de sus vidas.

Para finalizar, en los primeros compases de 2016, diversos especialistas sanitarios coincidían en que se podían dar por finalizados los contagios de Ébola en las poblaciones del oeste de África. Dejando el virus un balance final de más de 28.000 afectados y en torno a los 11.000 fallecidos, según las referencias proporcionadas por la Dra. Victoria Fumadó Pérez.

\section{El reconocimiento a un esfuerzo centenario, la concesión del Premio Princesa de Asturias de la Concordia 2015}

Consecuencia de los esfuerzos desplegados por los Hermanos de San Juan de Dios de cara a mejorar la salud de los enfermos y la atención constante hacia los colectivos más desfavorecidos de la sociedad durante casi cinco lustros, además de la consistente campaña llevada a cabo para erradicar la epidemia africana del Ébola, hemos de entender la concesión del Premio Princesa de Asturias de la Concordia ${ }^{53}$ en el año 2015.

Si bien, antes que nada, con objeto de ser más empíricos, conviene hacer una pequeña retrospectiva histórica con el fin de conocer algunas consideraciones previas a la entrega de tan distinguido galardón.

Como rápidamente podemos entrever, se trataba de un reconocimiento de máxima categoría a nivel nacional, con lo cual diferentes instituciones, colectivos y un buen número de personas optaban a ello, por sus trayectorias, méritos científicos o compromisos sociales.

Con todo, la candidatura hospitalaria fue extraordinariamente defendida por la profesora Marta Elvira Rojo, miembro del jurado de los Premios Princesa de Asturias, en la categoría de la Ciencias Sociales, logrando imponerse nada menos que a otras 27 propuestas de todos los rincones del planeta, igualmente destacadas.

53 GARCÍA RÍOS, José María. San Juan de Dios en España (1950-2020). Una respuesta desde la hospitalidad. Granada: Archivo-Museo San Juan de Dios "Casa de los Pisa", 2021. Colección Temas Históricos O.H. 
El 2 de septiembre de 2015, una vez conocido el fallo de los 30 miembros del jurado, la Fundación Princesa de Asturias difundía a los medios de comunicación que la Orden Hospitalaria había sido reconocida con la mencionada distinción debido a la centenaria labor asistencial llevada a cabo en los cinco continentes.

Evidentemente, tras aquella inesperada noticia las muestras de alegría de los diferentes responsables de la Familia Hospitalaria no tardaron en sucederse. Por ejemplo, el Hno. Jesús Etayo Arrondo, superior general de la Orden, que a la sazón se encontraba en Austria, declaraba en los siguientes términos:

«Es un premio que pertenece a las personas que la Institución atiende en el mundo. Muchas de ellas en riesgo de exclusión social, con un gran nivel de vulnerabilidad y entre ellas se encuentran personas enfermas, con dependencia, personas sin hogar, inmigrantes, personas con discapacidad y mayores. [...] Es un premio para toda la Familia Hospitalaria de San Juan de Dios, Hermanos, colaboradores y voluntarios que, día tras día, están al servicio de las personas. [...] Un premio a las personas que con generosidad se entregan hasta las últimas consecuencias: recordamos especialmente a los 18 Hermanos y colaboradores de nuestra Familia que hace un año fallecieron en Liberia y Sierra Leona a causa del Ébola; entre ellos los Hermanos Miguel Pajares Martín y Manuel García Viejo».

Al mismo tiempo, el Hno. Miguel Ángel Varona Alonso, como presidente de la Fundación Juan Ciudad, quiso aprovechar la oportunidad para dedicar la concesión del enjuiciado galardón a todas las víctimas de la Familia Hospitalaria fallecidas a causa del Ébola, sobre todo a la labor desarrollada por los Hermanos Miguel Pajares Martín y Manuel García Viejo, así como a los religiosos y colaboradores que diariamente trabajaban por y para el correcto funcionamiento de los establecimientos de la Orden.

Dicho organismo también aprovechaba aquella noticia para agradecer la resolución del premio a la presidenta de honor de la Fundación Princesa de Asturias, doña Leonor de Borbón; al vicepresidente, don Javier Fernández Fernández, presidente del Principado de Asturias; al presidente del Patronato, don Matías Rodríguez Inciarte, así como al resto de miembros del jurado que habían contribuido a aquella destacada distinción.

Aquel reconocimiento, desde luego, estaba íntimamente ligado a los esfuerzos desplegados por la Institución juandediana en su lucha contra el Ébola, como así se encargó de reconocer el propio jurado: 
«Durante la epidemia de Ébola, parte de su personal resultó contagiado falleciendo 18 personas entre Hermanos y colaboradores. No obstante, la Orden persistió en el trabajo para la pronta reapertura de los dos centros, con la formación del personal sobre protocolos de seguridad frente al virus, en coordinación con las autoridades sanitarias y otras instituciones internacionales, y continuó prestando información y asistencia a las familias en cuarentena con alimentos, medicinas y apoyo psicológico»

Además de lo cual, la Fundación Princesa de Asturias también quiso resaltar la actualización constante proyectada por los Hermanos de San Juan de Dios en sus estructuras socio-sanitarias y el fuerte impulso aportado a los campos de la investigación y la formación.

De este modo, el 20 de octubre de 2015 el Hno. Jesús Etayo Arrondo y el Hno. Pascal Ahodegnon, superior y consejero general, respectivamente, eran recibidos en el Hotel Reconquista de Oviedo por doña Teresa Sanjurjo González, directora de la Fundación Princesa de Asturias.Y acto seguido, daban paso a una rueda de prensa con los medios de comunicación para agradecer la mencionada nominación.

Para la Orden, tal como señalaba el Superior General, aquella distinción suponía «un honor, un estímulo y, a la vez, un compromiso para intentar hacerlo cada vez mejor, con más ahínco, para intentar resolver unas necesidades que siguen estando ahí». Asimismo, terminaba dedicando el premio «a las personas enfermas, a los que sufren, a los excluidos, que sólo salen en la prensa en situaciones tristes». Por otro lado, aprovechaba aquella magnífica plataforma mediática para poner parte de los recursos de la Institución al servicio de las administraciones con el fin de salir al frente de la crisis que vivían miles de refugiados sirios a causa de los conflictos bélicos.

El 21 de octubre de 2015 la delegación hospitalaria era recibida en la Junta General del Principado de Asturias por su presidente, don Pedro Sanjurjo González, dejando su impronta en el Libro de Honor de dicha corporación. Esa misma tarde, ambos religiosos -recordemos el Hno. Jesús Etayo Arrondo y el Hno. Pascal Ahodegnon- ponían dirección al Centro Sanitario Marítimo de Gijón, siendo recibidos por el Hno. Eloy Javier Castelo Rancho, responsable del establecimiento juandediano, y doña María del Carmen Moriyón Entrialgo, alcaldesa de Gijón.

Especialmente sugestiva para nuestra propuesta resultó la conclusión argüida por el Superior General de la Orden durante el discurso de agradecimiento por la nominación proyectado en la Junta 


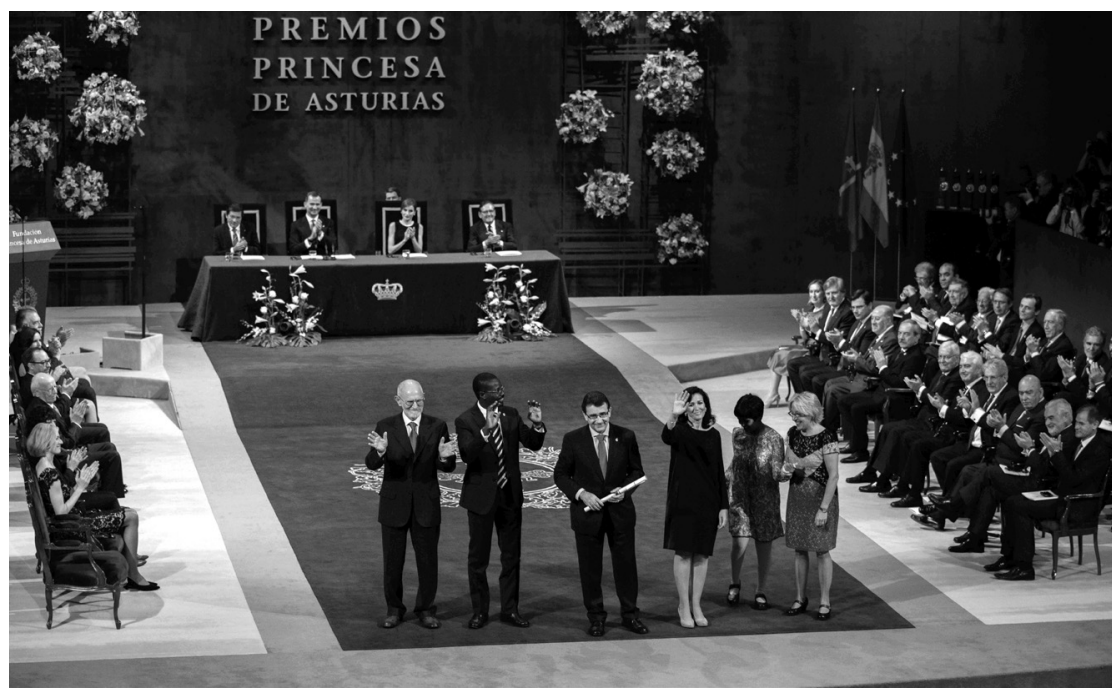

General del Principado de Asturias. He aquí una síntesis del mismo, que define a la perfección la misión de la Familia Hospitalaria:

«El Premio Princesa de Asturias de la Concordia 2015, y otros que hemos recibido últimamente, son un reconocimiento a nuestra misión, que agradecemos profundamente, porque expresan que el servicio que ofrecemos continúa siendo una respuesta válida y actual a nuestra sociedad. Pero sobre todo es un premio que pertenece a las personas enfermas y sus familias, a los pobres y necesitados a los que nos debemos y que son el centro de nuestros intereses. Pertenece también a todos los Hermanos, colaboradores y voluntarios que cada día y en cualquier lugar del mundo se desviven por acoger, asistir y practicar la hospitalidad con las personas que sufren y llegan a nosotros. Más allá de la alegría por el reconocimiento que significan, los premios son una llamada a toda nuestra Familia Hospitalaria de San Juan de Dios a empeñarnos más cada día por responder fielmente a nuestra misión, mejorando nuestro servicio y haciéndolo cada vez más accesible».

No obstante, tan sólo eran las primeras impresiones producidas por la noticia de la concesión del futuro reconocimiento, un exiguo y sucinto anticipo de lo que habría de venir con posterioridad.

Y, de este modo, por fin llegó el día esperado. Durante la mañana del 23 de octubre de 2015 tuvo lugar la recepción ante SS.MM. los Reyes de España, así como la entrega de las medallas de Asturias y de la insignia conmemorativa a todos los premiados en el Salón de Consejos del 
Hotel Reconquista. Por la tarde de ese mismo día, en las instalaciones del Teatro Clara Campoamor de Oviedo se procedía a la apertura de la ceremonia de entrega de los XXXV Premios Princesa de Asturias.

Resultando agraciados durante aquella gala: Wikipedia (Cooperación Internacional); Emmanuelle Charpentier y Jennifer Doudna (Investigación Científica y Técnica); Emilio Lledó Íñigo (Comunicación y Humanidades); Francis Ford Coppola (Artes); Leonardo Padura Fuentes (Letras), Esther Duflo (Ciencias Sociales), los hermanos Pau y Marc Gasol (Deportes) y, por último, la Orden Hospitalaria de San Juan de Dios (Concordia).

Para el momento de la entrega, por petición expresa del Superior General, se había acordado que el Hno. Jesús Etayo Arrondo fuese acompañado por una delegación de cinco personas que venían a representar a todos los integrantes de la Familia Hospitalaria. De tal modo, que el máximo responsable de la Institución juandediana acudió a recoger el galardón magníficamente escoltado por el Hno. Pascal Ahodegnon, cuarto consejero general; doña Marina Aliva Miranda Blanco, usuaria del Sanatorio Marítimo de Gijón, quien desfiló acompañada por su madre, doña María Ángeles Blanco, en representación de los enfermos y sus familias; doña María Isabel Herrero Panadero, directora asistencial de la Residencia San Juan de Dios de Sevilla, simbolizando a los colaboradores, y don Guillermo Vázquez Mata, director de cooperación del Consejo Andaluz de Colegios de Médicos y voluntario de Juan Ciudad ONGD durante la epidemia de Ébola en África, a nombre de todos los voluntarios de la Familia Hospitalaria. Desde luego, una decisión que estaba a la altura del mérito que se recibía.

Además, durante la ceremonia de entrega las tres demarcaciones religiosas españolas estuvieron representadas por una amplia y variada nómina de miembros de la Institución. Entre ellos, podemos destacar al Hno. José Antonio Soria Craus, superior provincial de la Bética; a don Juan José Afonso Rodríguez, director general de centros de dicha demarcación religiosa; a doña Gracia Polo Gaitán, responsable del voluntariado de Ciempozuelos; al Hno. Julián Sánchez Bravo, director de la Fundación Ciudad; al Hno. Miguel ÁngelVarona Alonso, presidente del antedicho organismo y superior provincial de Castilla; al Hno. Eloy Javier Castelo Rancho, superior del Sanitario Marítimo de Gijón, al Hno. José María Chavarri Imaña, al Hno. Antonio Blanco Rodríguez, al Hno. Ramón Castejón García, a don Francisco Muñoz Zamora, director general de centros de Castilla, así como al Hno. José 


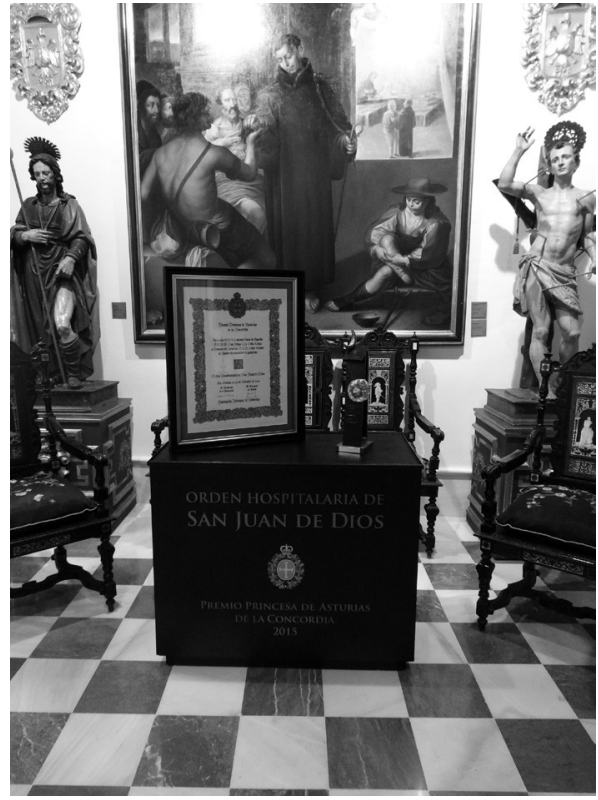

Luis Redrado Marchite, obispo de Ófena, o a doña María Dolores Sáenz Martínez, directora de la Junta de Gobierno de la Provincia de Aragón. Además, por supuesto, de los responsables de comunicación de las tres Provincias y de la Fundación Juan Ciudad.

Llegados a este punto, Felipe VI dedicaba unas palabras especialmente emotivas a la generosa misión llevada a cabo por los Hermanos de San Juan de Dios. Por la claridad de las mismas, no nos resistimos a reproducir un pequeño extracto de dicho parlamento:

«El Premio de la Concordia concedido a la Orden Hospitalaria de San Juan de Dios me recuerda las palabras que dediqué el año pasado en este escenario a todas las personas que, sobre todo en África, luchan con entrega, generosidad y profesionalidad contra la pobreza y las enfermedades, como el Ébola. En particular, a tantos cooperantes, voluntarios y religiosos españoles que trabajan -que se entregan- por todo el mundo, para aliviar el sufrimiento de los más desfavorecidos. Unas palabras que quiero repetir ahora: todos ellos son, todos vosotros sois, un verdadero orgullo para España.En esta tarea, la Orden Hospitalaria es ejemplar. Los hospitalarios, que conocen muy de cerca el dolor humano, desempeñan una labor abnegada, pero inherente a su razón de ser, a su fe, a su sentido del deber. Por eso, además, su ejemplo, sublime de compasión y caridad, de generosidad y alegría, es una llamada de alerta constate para todos nosotros.Cuando con su obra dan testimonio de vida verdadera, sabemos que sin su entrega, sin su misericordia, todos estaríamos un poco más solos, un poco más desprotegidos. Les damos las gracias desde el fondo de nuestros corazones por esa labor humilde y grande al mismo tiempo...».

Después de la entrega de los galardones, un amplio grupo de Hermanos, colaboradores y algunos pacientes y familiares de la 
Institución Hospitalaria tuvieron ocasión de disfrutar de una recepción oficial con los reyes en el Hotel Reconquista.

Evidentemente, los plácemes y felicitaciones no se hicieron esperar. La acción de gracias y las dedicatorias por aquel reconocimiento estaban más que justificadas. Eso se desprendía de las palabras del Hno. José Luis Fonseca Bravo, superior provincial de Aragón, a los lectores de Información y Noticias, quien, además de felicitar a todas las personas que habían contribuido a la recepción del prestigioso galardón, aprovechó para relatar la dramática situación que vivían muchas familias debido a la crisis económica y social por la que atravesaba el país, así como arrojar algo de luz sobre la realidad de cientos de refugiados:

«Es un reconocimiento público a una trayectoria institucional de casi 500 años de andadura. [...] Un premio que llega en momento providente. Inmersos en medio de una gran crisis humana de valores y en donde miles de refugiados y personas inician la búsqueda hacia nuevas oportunidades para sus vidas rotas por variables que no pueden dominar.

[...] Este reconocimiento ha de constituirse como un estímulo para recrear un futuro nuevo en la hospitalidad. Este reconocimiento es una llamada a comprometernos más con los desfavorecidos, a construir más fraternidad desde el don de la hospitalidad, a luchar con todas nuestras fuerzas y empeño personal e institucional por un mundo en el que todas las personas puedan gozar de idénticas oportunidades para disfrutar de una vida digna y adecuada como hermanos que somos en la gran fraternidad universal».

Para finalizar, aunque exiguo, un extracto del acta del jurado de los Premios Princesa de Asturias, donde se recogen los méritos y decoros llevados a gala durante tantos años por la Institución Hospitalaria:

«Reunido en Oviedo el jurado [...] decide conceder el Premio Princesa de Asturias de la Concordia 2015 a la Orden Hospitalaria de San Juan de Dios como reconocimiento a una ejemplar labor asistencial desarrollada a lo largo de cinco siglos. Presente en más de 50 países, se centra en los difíciles momentos que hoy vive el mundo, en cuestiones tan sensibles como la epidemia del Ébola, las crisis migratorias y, en general, la protección de las personas más desfavorecidas y en riesgo de exclusión. Oviedo, 2 de septiembre de 2015» 


\subsection{La pandemia que nos ha confinado: La Covid 19}

\section{PANDEMIA COVID-19 $\{2020 / . . . ?\}$}

Atrás hemos dejado todo un rosario de episodios de enfermedad y amenaza para la especie humana. Son de otro tiempo, parecen lejanas pero hoy vivimos "nuestra propia pandemia"y tiene un nombre. Un nombre aceptado por la comunida científica. Pero nos ha cogido desprevenidos, confiados, desprotegidos... ¿Nos considerábamos a salvo de esta amenaza? Los acontecimientos y las cifras así lo confirman.

En lo referente a esta pandemia hemos tenido y seguimos teniendo demasiada información (o tal vez sea más desinformación) desde los ámbitos mundiales y locales. Por resultar concretos y delimitando el ámbito de la Orden Hospitalaria, nos ha parecido oportuno ceñirnos a las fuentes de información próximas y de mayor rigor.Y nadie mejor que el superior general de la Orden de San Juan de Dios, explica su papel en esta crisis sanitaria, y narra los acontecimientos más próximos. Información esta que está registrada en las diversas webs general o provinciales y locales así como redes sociales, en donde ha quedado claramente reflejado el proceso y las actuaciones que se han tenido al respecto en estas circunstancias, tensas, precipitadas pero siempre intentando vivirlas con serenidad y al estilo de Juan de Dios que nos inculcó desde el principio y que hemos podido comprobar con algunas de las actuaciones de sus seguidores a lo largo de la historia de la institución de las epidemias, pestes u otras enfermedades sufridas. Si hay una institución que se ha topado de frente con la pandemia es la Orden Hospitalaria de San Juan de Dios. "Los enfermos son el centro de todos nuestros desvelos. Es nuestra hora, no podemos escondernos. Tampoco podemos hacerlo cuando termine la crisis sanitaria, porque llegará la económica y social". Nos está afectando en nuestras obras a nivel sanitario y asistencial, a nivel económico, social y espiritual. No todos los centros de la Orden han atendido enfermos de Covid-19, pero muchos sí y en otros muchos han sufrido contagios, que en general se han ido controlando bastante bien. A nivel económico y social, en muchos lugares se ha debido parar la actividad, creando un perjuicio económico grande que, en 
algunos lugares, como África, puede poner en peligro la continuidad de algunos centros ${ }^{54}$.

Todos los centros se han puesto de inmediato a disposición de las autoridades sanitarias para colaborar en todo lo necesario en esta dura pandemia que estamos viviendo. En algunas ocasiones nos han pedido ser hospitales Covid, o sea, dedicados a la atención de enfermos con coronavirus, y en otras ocasiones nos han pedido dedicarnos a asistir a enfermos con otras patologías. Hay que tener en cuenta que nuestra Orden, además de hospitales,

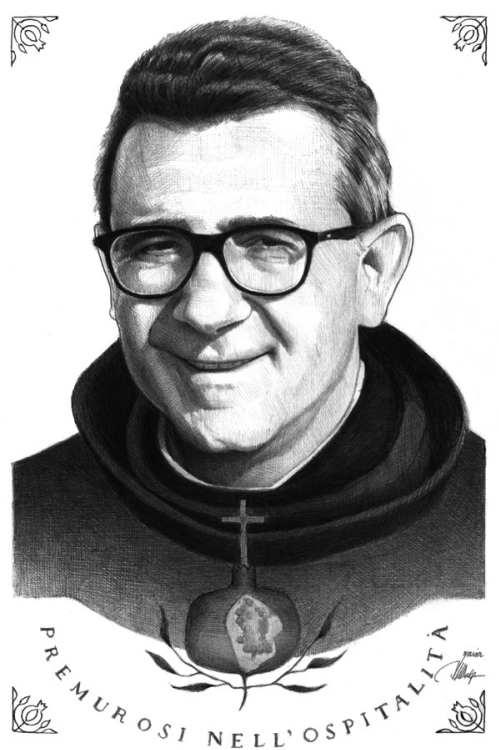
cuenta con muchos otros centros para ancianos, enfermos mentales, personas diversamente hábiles -físicas y psíquicas-, centros para inmigrantes, sin techo, etc. Ha sido y sigue siendo un gran desafío mantener todos estos centros libres de Covid-19. Nuestro carisma y nuestra misión es la hospitalidad y siempre hemos de estar preparados. La pandemia ha sido y es una emergencia, por tanto, para nosotros es un momento de emergencia carismática para dar lo mejor de nosotros mismos al servicio de los enfermos en esta situación tan difícil. Dicho de otro modo, es lo que llamamos la hora de la hospitalidad. La hora de salir a asistir, a cuidar, acompañar, ofrecer, dar todo por amor a Dios y a los enfermos.

En este momento no perseguimos ni deseamos hacer una crónica, sino trazar ligeras pinceladas que, de forma sinuosa y progresiva ha ido marcando la implicación de esta pandemia de la Covid-19 en los Centros de la Orden Hospitalaria de San Juan de Dios dentro de los contextos mundiales. En síntesis y, seleccionando de algunos de los textos enviados por 11 Hermano General, Jesús Etayo o.h.,

54 Cartas Circulares Superior General Orden Hospitalaria. Crisis Covid-19. [2020/21] Archivo - Museo San Juan de Dios"Casa de los Pisa". Granada 
destacamos y vemos la evolución, tanto de las actuaciones como de las cifras de personas atendidas y fallecidas, en función de las fechas de los escritos que resultan marcar una evolución muy acertada. Para conocer la actuación de la Orden en otros momentos de crisis no siempre hemos dispuesto de una fuente tan valiosa como en esta ocasión. Así que aprovecharemos para hacer historia la colección de circulares del Superior General con motivo de este momento, sin duda trascendente, ofreciendo un extracto ordenado y sistemático de las mismas:

Roma, 30 de marzo de 2020: Los medios de comunicación nos dan a diario los datos de cómo está afectando la pandemia en el mundo. Hasta el día de hoy se han contabilizado más de 700.000 contagios, 34.000 fallecimientos y 149.000 curaciones en el mundo. Estados Unidos es la nación que más contagios tiene hasta el momento, pero sigue siendo Europa, especialmente Italia y España seguidas de Francia, Alemania y otros países, donde la pandemia crece con más fuerza y con más fallecimientos. Por desgracia el virus está llegando cada vez más a todos los continentes, [...] por lo que en gran parte del mundo se están tomando medidas preventivas muy restrictivas. China es el único país por el momento, donde parece que el virus está retrocediendo y se están retirando algunas medidas de restricción. Esta situación está creando una crisis sanitaria grande, cuyas dimensiones todavía no podemos adivinar, pero también unas crisis económicas y sociales muy importantes. No hay Hermanos contagiados en ninguna Casa de la Orden a excepción de Italia donde tenemos un Hermano que ha dado positivo al coronavirus y de España donde hay 14 Hermanos actualmente con resultado positivo. A día de hoy la mayoría están aislados en las Comunidades y algunos ingresados en el hospital, con atención médica. Respecto a los Colaboradores y aunque no tenemos una información precisa de todas las Provincias, les puedo decir que al menos hay un número en torno a 280 que han dado positivo al coronavirus. Esto está creando algunas tensiones en algunos Centros por la escasez de personal, ya que en muchas ocasiones otros tantos Colaboradores deben hacer cuarentena si han estado en contacto con una persona que ha dado positivo. En cuanto a fallecimientos por la Covid-19 en nuestras Casas, hay un cierto número de pacientes que han fallecido, sobre todo en algunos hospitales que, a petición de las Administraciones públicas, 
están atendiendo enfermos con coronavirus. Por lo que se refiere a Hermanos, en total hasta la fecha han fallecido dos Hermanos, uno de 97 años [...] y otro de 88. El resto de Hermanos fallecidos durante la semana anterior no fue a causa del virus. En cuanto a Colaboradores, solo tenemos la información del fallecimiento de un Colaborador en Italia, que estaba en excedencia laboral.

Descrita la situación, el Superior General recomienda afrontarla al estilo de San Juan de Dios: Quiero agradecer a todos los Hermanos y Colaboradores que estos días están dando lo mejor de sí mismos para asistir a los enfermos y sus familias, en la lucha contra esta pandemia. Sabemos además que lo estáis haciendo en condiciones muy difíciles, sobre todo en los países más afectados, por la falta de material y la saturación de enfermos que os llegan. Gracias mil veces. San Juan de Dios os sostiene y os acompaña con su presencia y su intercesión.

Roma, 14 de abril de 2020: Este año hemos vivido la Semana Santa y hemos celebrado la Pascua de una forma inusual y diferente en la mayor parte del mundo, a causa de la pandemia del coronavirus. El confinamiento de gran parte de los países ha hecho que muchas personas y también comunidades religiosas hayan tenido que vivir las celebraciones por televisión o de forma virtual. Hemos visto las celebraciones del Vaticano con una basílica de San Pedro vacía, con una sensación extraña. Así nos ha tocado vivirla este año y así hemos entrado en la Pascua, con la alegría y la esperanza de que la vida que nos trae el Cristo Resucitado sea la última palabra y nos ayudará a superar este tiempo de dolor, de sufrimiento y de muerte que estamos viviendo. En el momento actual, Estados Unidos es la nación con el mayor número de contagiados y fallecidos, seguida de varios países de Europa, entre los que continúan destacando Italia, España, Francia, Alemania y Reino Unido. El virus ha llegado también a América Latina y África, donde el impacto no es muy grande por el momento, aunque habrá que seguir la evolución en las próximas semanas. Asia, Australia y el Pacífico, en línea con las anteriores informaciones. Gran parte del mundo estamos confinados, en espera de que se pueda controlar la situación. Por el momento solamente China ha iniciado la etapa del desconfinamiento, con algunas restricciones, por prudencia, ya que nadie conoce con exactitud el comportamiento del virus. En lo que se refiere a la Orden, la Covid-19 está siguiendo los mismos patrones que a nivel del mundo. Hasta el día de 
hoy y teniendo en cuenta la información que nos ha llegado, cuatro Hermanos fallecieron a causa del coronavirus (dos de Aragón, uno de Andalucía y uno de Francia). Varios Hermanos se han contagiado por el virus, la mayor parte en España, uno en Italia y dos en Francia, uno de los cuales falleció. En España además de los Hermanos fallecidos, doce ya se curaron y dieron negativo y 18 siguen en proceso de curación, que esperamos se confirme en los próximos días, al igual que el Hermano de la Provincia Lombardo Veneta y de Francia que siguen positivos al test de la Covid-19. En relación a los Colaboradores, un importante número se ha contagiado, en gran parte debido a que en un buen número de hospitales de la Orden se asiste a enfermos con coronavirus. No tenemos los datos exactos, pero podemos decir que en torno a 300 Colaboradores, la mayoría en España e Italia -pero también algunos en otros países e incluso hemos conocido hoy los primeros casos en África-, han dado positivo al test del coronavirus, con los correspondientes casos de compañeros que han debido guardar la cuarentena. Poco a poco van curándose y no tenemos noticia de fallecimientos, desde la última información. Muchos pacientes con Covid-19 están siendo asistidos en los hospitales de la Orden. Un buen número de ellos se van recuperando pero tristemente algunos también fallecen, al no poder superar la infección. También ha habido algunos fallecimientos en residencias de ancianos, aunque en general se está haciendo un buen trabajo para evitar los contagios.

Descrita la situación, el Superior General recomienda afrontarla al estilo de San Juan de Dios: Quiero en esta ocasión, hacer mención precisamente a las Residencias de Ancianos, a los Centros de Salud Mental, a los Centros de Discapacitados y a los Centros de atención de personas sin hogar, inmigrantes o personas excluidas. Como saben, son Centros de especial riesgo y es necesario extremar todas las medidas para evitar los contagios, dado que si no estamos atentos el problema puede ser muy grande. Hay que escuchar a los técnicos y seguir la normativa prevista. Pero de entrada en estos Centros y en estos momentos, deben existir solo la parte de los que están contagiados y la parte de quienes no lo están, evitando a toda costa nuevos contagios. Deseo agradecer a la región de América Latina el trabajo de coordinación y ayuda que están realizando entre todas las Provincias y Delegaciones, para aunar criterios y trabajar con los estándares apropiados en todos los sentidos. Igualmente desde hace varias semanas se creó una Unidad de Crisis para África, coordinada 
por la Fundación Juan Ciudad, con la participación de diversas entidades de la Orden en Europa (Irlanda, Holanda, Italia), la Provincia de San Agustín, la Oficina de Misiones y Cooperación Internacional de Curia General, con el fin de asesorar y ayudar a las Casas de las dos Provincias de África sobre todo, estableciendo los protocolos que se deben seguir, conociendo las necesidades y enviándoles algunos recursos para adquirir el material de protección necesario para una primera fase. Este grupo sigue trabajando y evidentemente, según como vaya afectando el virus, irá viendo cómo seguir ayudando a las Casas en África.

Roma, 28 de abril de 2020: La pandemia del coronavirus sigue avanzando y prácticamente ha llegado a todo el mundo. Los contagios aumentan cada día, así como el número de fallecidos y también, gracias a Dios, el número de personas curadas. Lo que va cambiando poco a poco son las fases en las que cada país está pasando la pandemia. Mientras en muchos países apenas han comenzado o siguen en la fase del confinamiento, otros países están iniciando y preparándose para la siguiente fase del desconfinamiento. Ciertamente con muchas dudas e incertidumbres sobre lo que pueda pasar en esta etapa de "convivencia con el virus", dado que todavía hay muchas cosas que se desconocen del mismo. En cuanto a la afectación de la Covid-19 en la Orden, teniendo en cuenta la información que nos ha llegado hasta el día de hoy, los datos son los siguientes: Se han contagiado un total de 43 hermanos, de los cuales, 5 han fallecido, 24 ya se han curado y 14 continúan contagiados, en fase de recuperación. De estos últimos, ocho son de las Provincias de España, cuatro de la Provincia del Buen Pastor (uno de ellos pertenece a la Provincia de Corea, que está haciendo un tiempo de estudio en Canadá), uno pertenece a la Provincia de Francia y otro hermano a la Provincia LombardoVeneta. Respecto a colaboradores contagiados, no tenemos un dato preciso, además muchos de los que se contagiaron hace un cierto tiempo, ya se han curado y reincorporado a su trabajo. No obstante al menos 300 colaboradores están actualmente contagiados, especialmente de España, Italia y Colombia, donde hace unos días conocimos el contagio de 42 colaboradores aproximadamente en uno de los centros de Bogotá. En África, por las noticias que tenemos siguen algunos pocos contagiados en el hospital de Monrovia (Liberia). En el resto del mundo donde está presente la Orden no tenemos noticias de ningún 
otro contagiado. En algunos de nuestros hospitales y centros han fallecido un buen número de personas a causa de la Covid-19. Por otro lado algunos residentes en centros de la Orden también han fallecido por el virus, bien en los propios centros o en otros hospitales donde fueron derivados. Para todos ellos y sus familias, nuestra oración y nuestras condolencias. La pandemia no solo está creando problemas de salud, que sin duda son los más urgentes atender. Estamos viendo ya con mucha claridad que como consecuencia de dicha pandemia está llegando una crisis importante a nivel económico, social y de bienestar psicológico y espiritual. Nos preocupa mucho esta realidad porque va a afectar a todo el mundo y de modo especial impactará sobre las personas y las naciones más vulnerables. Muchos están viendo venir las dificultades para el sostenimiento de los centros, debido a la bajada de actividad, a la crisis económica que está llegando y al temor de tener que cerrar algún centro por los contagios o por falta de recursos. Es necesario desde este mismo momento gestionar la realidad de cada centro teniendo en cuenta todas estas realidades y tomando todas las medidas necesarias y posibles que permitan el sostenimiento de los mismos. Como siempre contamos con la generosidad de la Orden y de todas sus Provincias, pero en esta ocasión debemos pensar que la crisis es de orden mundial y será difícil poder atender todas las demandas.

Descrita la situación, el Superior General recomienda afrontarla al estilo de San Juan de Dios: Ante el momento difícil que vivimos y, el que parece ser viviremos en todo el planeta en los próximos meses y años seguramente, se nos invita a toda la Orden, a toda nuestra Familia Hospitalaria de San Juan de Dios, a dar lo mejor de nosotros mismos: la hospitalidad al estilo de san Juan de Dios. Todos, Hermanos y colaboradores, somos llamados a salir de nosotros mismos para asistir a las personas enfermas y también a las personas pobres y vulnerables que la pandemia comienza a dejar ya por el camino. Lo debemos hacer con todas las medidas preventivas necesarias, pero nuestra misión de hospitalidad nos llama a ello, a dedicarnos a nuestros Hermanos necesitados, como lo hizo san Juan de Dios y muchos otros Hermanos. Es preciso recordar que debemos poner especial atención en la asistencia espiritual y religiosa en los centros, sin descuidarla en ningún momento. Guardando las normas de protección, pero dando alivio espiritual y humano a los enfermos y familiares, a los colaboradores y voluntarios. Junto al ejército de los 
demás Hermanos y colaboradores, estáis llamados a hacer presente el amor de Dios a quienes sufren. Es la hora de la hospitalidad y nosotros somos llamados por el Señor y por la Iglesia, a ser la vanguardia del amor samaritano de Dios a sus hijos más frágiles y vulnerables. En estas fechas se publicó un breve documento, elaborado por la Comisión General de Bioética de la Orden, cuyo responsable es el Hno. Joaquín Erra, primer Consejero General. Es una reflexión que pretende ayudarnos a identificar los elementos fundamentales que está produciendo la pandemia, aportando algunos criterios y propone algunos recursos que pueden ser útiles para todos.

Roma, 20 de mayo de 2020: A día de hoy en el mundo son casi cinco millones de personas diagnosticadas positivas a la Covid-19 y más de 325.000 personas fallecidas. Son también muchos miles de personas que se han curado. Sin embargo la pandemia sigue avanzando, en algunos lugares por primera vez y en otros con temor a nuevas olas de contagio. Todos en espera de una vacuna que sea eficaz y llegue a toda la población mundial, lo cual tardará un tiempo, todavía por determinar. En muchos lugares del mundo y gracias a las medidas restrictivas de emergencia que se han tomado, se han reducido mucho los contagios y fallecimientos. En estos momentos estos países están iniciando una nueva fase, con menos restricciones, con el fin de volver poco a poco a lo que algunos llaman la "nueva normalidad", pero con muchos temores a dar pasos atrás por nuevos focos de contagio. En otros lugares todavía siguen las restricciones severas y en otros se espera todavía, la llegada más virulenta del coronavirus. En lo que respecta a la Orden, a las comunidades y a los centros, la situación en general es bastante más tranquila en estos momentos. La mayoría de los Hermanos que fueron contagiados, son ya negativos, a excepción de tres, que esperamos lo sean en los próximos días. Sin embargo, a pesar de ser ya negativos, en algunos casos las secuelas que el virus les ha dejado, hace que todavía necesiten tratamiento y cuidados médicos. Lo mismo sucede con los Colaboradores. Han sido muchos los que se contagiaron, pero gracias a Dios la mayoría ya están bien. Todavía queda un grupo significativo y últimamente hay que lamentar el fallecimiento de un Colaborador de Colombia. En relación a personas enfermas con Covid-19 asistidas en nuestros centros, también están disminuyendo bastante. Todavía hay varios hospitales, especialmente en Europa, que continúan atendiendo enfermos de 
coronavirus. Se han atendido más de 2.000 enfermos de coronavirus, de los que en torno a 300 han fallecido. Cuando en muchos países estamos entrando en la fase dos, porque los contagios y fallecimientos por causa del virus han disminuido considerablemente, nos damos cuenta que los efectos de la Covid-19 no son solamente sanitarios, sino también sociales, económicos, espirituales e institucionales.

Descrita la situación, el Superior General recomienda afrontarla al estilo de San Juan de Dios: A nivel institucional, de la Orden, estamos previendo dificultades importantes para muchos centros y obras de la Orden, a causa de la crisis producida por la pandemia: centros que han debido cerrar muchos servicios, otros que ven disminuida enormemente su actividad porque los pacientes no llegan y otras razones que pondrán en crisis a muchas de nuestras estructuras. Debemos preverlo y gestionarlo del mejor modo posible, haciendo planes concretos para este momento en los que debemos adecuar los servicios y los recursos para no crear deudas excesivas que luego lastren su viabilidad. Deberemos también, en la medida de nuestras posibilidades, estar disponibles para ayudarnos dentro de las propias Provincias, y también debemos estar abiertos a ayudar a otras Provincias y centros más desfavorecidos por su situación y por la afectación de la pandemia. Como siempre no dudamos de la generosidad y hospitalidad con todas las obras y personas de nuestra Orden. Es la hora de la hospitalidad con nuestra Familia Hospitalaria de San Juan de Dios. Otras consecuencias de la pandemia son las dificultades que se producen a nivel de las relaciones humanas, a nivel de salud mental y a nivel espiritual y religioso. [...] Se anima a todos los Servicios de Atención Espiritual y Religiosa para la atención de esta dimensión a los enfermos, familiares y colaboradores. [...] Esta invitación se extiende, no solo a los SAER sino también a todos los Hermanos y Colaboradores del ámbito de la salud mental y en general a todos los miembros de nuestra Familia de San Juan de Dios, para estar disponibles a escuchar, acompañar, atender y ayudar a todas las personas que sufren cualquier dificultad en estas dimensiones, ya que las consecuencias personales, familiares, sociales y económicas que está dejando la pandemia, son muy grandes y están produciendo mucho sufrimiento. Por ello para toda la Orden y los que formamos parte de ella es la hora de la hospitalidad... la de la escuchar, acompañar y dar esperanza. 
Roma, 30 de junio de 2020: El epicentro de la pandemia ya no es Europa, sino que éste ha pasado a América, tanto del Norte, especialmente Estados Unidos, como del Centro y del Sur, siendo los países más golpeados Brasil, Perú, Chile y México, aunque también la situación es preocupante en otras naciones de la región. Otro foco importante que está creciendo es India, con más de medio millón de contagiados y más de 15.000 fallecidos. En el continente africano por el momento la pandemia del coronavirus no está golpeando con mucha fuerza, aunque están subiendo el número de contagios y se teme que más adelante pueda crecer mucho más, lo cual esperamos que no ocurra para bien de todos. En Europa y en países como China, Corea, Australia y otros, la situación ha mejorado, han terminado prácticamente los confinamientos y cuarentenas, se está volviendo a lo que se llama "la nueva normalidad", que implica medidas de prudencia y seguridad. El temor es no dar pasos atrás que nos lleven a nuevos confinamientos, aunque ya tenemos frecuentes focos de contagios que por el momento están bajo control. Existe un cierto temor, indicado también por los especialistas, a nuevas oleadas de contagio más adelante, al menos hasta que no exista una vacuna eficaz, lo cual parece que tardará, aunque se acorten los tiempos de preparación. En relación al impacto de la Covid-19 en la Orden, va variando en función del epicentro del mismo. Mientras el foco principal fue Europa, el impacto fue muy alto como todos saben. En este momento ha disminuido mucho y parece que todo está bajo control. En cuanto a los Hermanos de la Orden, a día de hoy no hay ninguno en todo el mundo que esté contagiado. En total han sido 47 los religiosos contagiados, de los que cinco fallecieron, y 42 se han recuperado satisfactoriamente. El número de Colaboradores que han dado positivo al test del coronavirus ha sido muy elevado. Todos se han recuperado excepto tres que desgraciadamente fallecieron. No tenemos un número exacto de Colaboradores contagiados durante la pandemia, pero al menos han sido 800 los que se han contagiado. De ellos en torno a 200 siguen contagiados, la mayor parte en Casas de América. Algunos en Europa, cada vez menos, y muy pocos en África, todos bajo control. Si tenemos en cuenta las personas contagiadas por coronavirus que han ingresado en nuestros hospitales, más las personas que fueron positivas al virus en nuestros centros residenciales y sociales, hasta el día de hoy han sido atendidos en 
nuestras Casas cerca de 4.000 pacientes, de los que han fallecido en torno a 400.

Descrita la situación, el Superior General recomienda afrontarla al estilo de San Juan de Dios: En muchos lugares, sobre todo donde parece que las cosas están más controladas, se habla de"nueva normalidad". [...] Podemos salir y encontrar a los Hermanos, a las familias, a los amigos, pero siempre "con cuidado". De todas formas ya es mucho, para quien ha tenido que estar meses "recluido" en casa. Podemos ya trabajar, pero con cuidado, con atención a las reuniones etc., de ahí el teletrabajo que parece se impondrá definitivamente y las diversas plataformas on line que nos permiten hacer reuniones de cualquier otro tipo. Podemos ir al bar, al restaurante, podemos viajar a determinados lugares... pero siempre "con cuidado", hasta que exista una vacuna eficaz. Esta nueva normalidad se caracteriza por tanto por la incertidumbre. No debemos ni podemos bajar la guardia. También se caracteriza por la responsabilidad, pues desoír las llamadas a la prudencia puede, además, afectar a los demás. La generosidad y la solidaridad caracterizan necesariamente este momento que vivimos, porque el coronavirus amenaza la vida de las personas, la forma de vivir e incluso el modo y los medios de vivir, ciertamente y como siempre sucede, más a los más pobres y vulnerables. Por eso y finalmente, esta fase novedosa de la nueva normalidad requiere para afrontarla con garantía de la hospitalidad: que ante la incertidumbre, es responsable, generosa y solidaria, inclusiva y acogedora.

Roma, 31 de julio de 2020: Los contagios de la Covid-19 siguen aumentando cada vez más y el número es cada vez mayor: a día de hoy son prácticamente 17 millones de personas contagiadas en todo el mundo, de las que más de 660.000 han fallecido. Estados Unidos, Brasil y la India son los países con más casos positivos. Junto a ellos siguen siendo muy golpeados por la pandemia algunos países de América Latina, como México, Perú, Chile, Argentina y Bolivia. Esperamos que en los próximos meses baje la incidencia y la fuerza del virus en estos países, ahora tan golpeados. En África hasta la fecha el impacto no ha sido muy fuerte, pero poco a poco van creciendo los contagios, sobre todo en Sudáfrica y algunos otros países. Por el momento en los países donde está presente la Orden, la situación está relativamente controlada y en nuestros Centros de África apenas hemos tenido casos positivos. En Europa y en países como China, 
Corea, Australia y otros, que pasaron los momentos difíciles al inicio de la pandemia, la situación está mejor, si bien se suceden los brotes de nuevos contagios, que invitan a todos a ser muy prudentes y a mantener todas las medidas de prevención, incluso volviendo a medidas más restrictivas de nuevo. En algunos lugares los nuevos brotes de contagios está costando controlarlos más e incluso se habla de la posibilidad de nuevas oleadas en los meses venideros. En definitiva todos tenemos claro que hasta que exista una vacuna eficaz deberemos acostumbrarnos a convivir con el virus. En relación al impacto de la Covid-19 en la Orden, el foco principal sigue estando en estos momentos en América, especialmente del Sur. Algunas Casas han pasado o están pasando por momentos difíciles. Concretamente en nuestras Obras de Latinoamérica los últimos datos que tenemos son los siguientes: 330 Colaboradores contagiados, uno de ellos fallecido; 779 pacientes positivos al virus con 21 fallecidos y 3 Hermanos positivos, uno de ellos hospitalizado. En cuanto a los Hermanos de la Orden y teniendo en cuenta los datos indicados antes, hasta el este momento han sido 51 los religiosos contagiados y 43 se han recuperado satisfactoriamente. El número de Colaboradores que han dado positivo al test del coronavirus, además de lo dicho para América Latina, en el momento actual hay algunos más en los otros continentes, pero la incidencia es muy pequeña por el momento. De todas formas en el conjunto, desde el inicio, más de 1.000 Colaboradores se han contagiado, falleciendo tres. Es difícil calcular con exactitud el número de personas contagiadas por coronavirus que han ingresado en nuestros hospitales y aquellas que han sido positivas al virus en nuestros centros residenciales y sociales. Sin embargo, hasta el día de hoy han sido atendidos en nuestras Casas alrededor de 5.000 pacientes positivos, de los que han fallecido en torno a 500. Estos son los datos de la pandemia y el impacto en el mundo y en la Orden. No sabemos cómo seguirá evolucionando, pero es claro que seguirá conviviendo con nosotros, al menos hasta la existencia de una vacuna eficaz. Es verdad que poco a poco vamos conociendo y aprendiendo más cosas del virus, lo que nos permite prepararnos mejor para controlarlo y afrontarlo, aunque no todos los países cuentan con los mismos medios. De hecho la pandemia está atacando fuertemente la economía mundial y en concreto la de muchos países, de por sí ya en situación difícil, lo cual está produciendo muchos otros elementos nocivos en términos de salud física y psicológica, de 


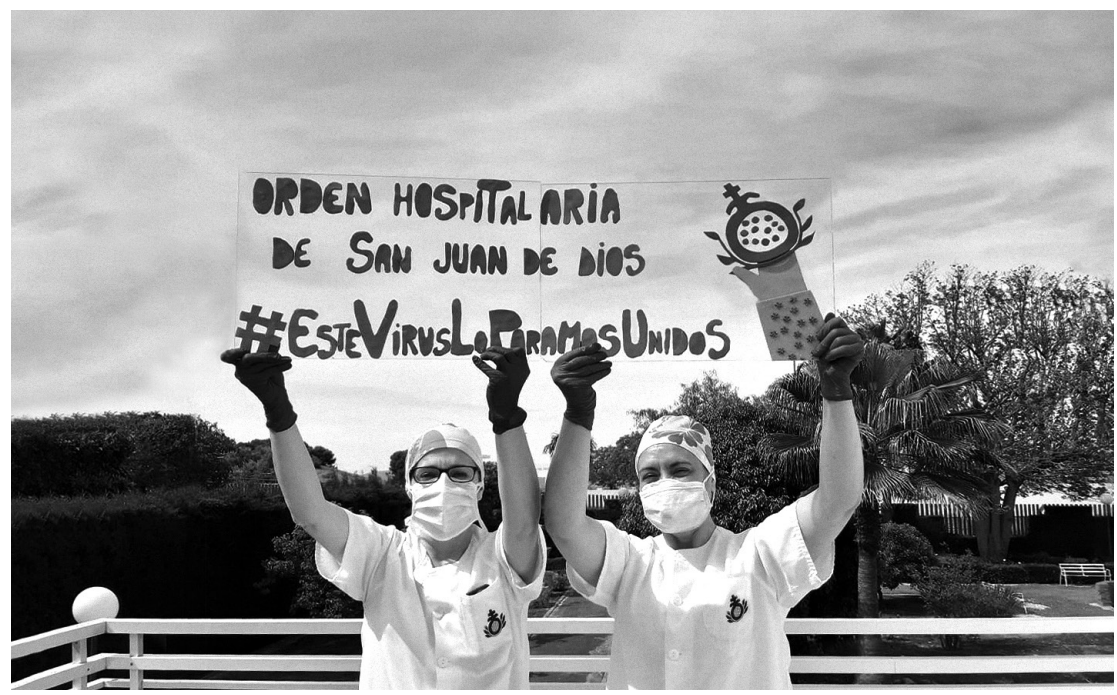

desempleo, pobreza, hambre y otras enfermedades que no se atienden adecuadamente por causa de la Covid-19.

Descrita la situación en Superior General recomienda afrontarla al estilo de San Juan de Dios: El tiempo va pasando y la pandemia sigue impactando y golpeando. Es normal que crezca la incertidumbre y en ocasiones el pesimismo ante los hechos que se suceden, incluidas las decisiones y actuaciones poco educativas de algunos políticos, que todos hemos podido conocer por los medios de comunicación social. Por eso más que nunca, en estos momentos es importante seguir llamando a todos, especialmente a los jóvenes, a la responsabilidad, la generosidad y la solidaridad con quienes son contagiados, con quienes son población de mayor riesgo, como las personas mayores, enfermas, excluidos y maginados, con quienes más directamente sufren las consecuencias de la pandemia por la pérdida del empleo y cualquier otra circunstancia social, psicológica y espiritual. Dado que la pandemia sigue creciendo con fuerza, la mejor garantía para afrontar esta situación es la hospitalidad. Nuestra Familia Hospitalaria de San Juan de Dios, vivimos una emergencia carismática, en la que hemos de dar lo mejor de nosotros mismos al servicio de los pobres, enfermos y necesitados, primero durante la crisis sanitaria, pero también durante la crisis económica y social que continúan y que muchas veces conviven al mismo tiempo. 
Roma, 18 de septiembre de 2020: A día de hoy nos acercamos a los 30 millones de personas contagiadas y a los 950.000 fallecidos en todo el mundo. Conocemos las consecuencias de la pandemia tanto a nivel sanitario como social y económico, aunque todavía no sabemos las dimensiones de dichas consecuencias, que serán importantes según todos los analistas. Esta situación está impactando muy significativamente en nuestra vida, sobre todo en el estilo de vida y también en nuestros programas y actividades, que vienen muy mediatizadas por la pandemia. Ello nos está llevando a desarrollar la creatividad y a buscar nuevas formas de trabajar y de relacionarnos y nos está haciendo más sensibles a la solidaridad y a la búsqueda del bien común. Estando así y aunque se han hecho progresos importantes para el tratamiento de la Covid-19, la esperanza de una solución definitiva se pone en la vacuna. Muchos grupos de investigación en varios países vienen trabajando velozmente en ella, de modo que algunas están muy adelantadas e incluso se piensa que a finales del presente año o inicios del próximo podrán estar disponibles, aunque antes deberá comprobarse la eficacia y sobre todo la seguridad. Hasta que eso llegue, hemos de vivir sin miedo, pero hemos de ser muy prudentes, guardar las medidas de seguridad que se nos piden y ser muy responsables, protegiendo especialmente a las personas más vulnerables. En relación al impacto de la Covid-19 en la Orden [...], el foco principal sigue estando en estos momentos en América, especialmente del Sur. Los últimos datos acumulados que tenemos de esta Región son los siguientes: 526 Colaboradores contagiados, uno de ellos fallecido; 1.692 pacientes positivos al virus con 53 fallecidos y 16 Hermanos positivos, de los cuales en la actualidad 8 siguen positivos en casa y uno ha fallecido recientemente en la Provincia de Colombia. En cuanto a los Hermanos de la Orden y teniendo en cuenta los datos indicados antes, hasta el este momento han sido 65 los religiosos contagiados, seis fallecidos y 49 se han recuperado satisfactoriamente y 10 siguen siendo positivos en la actualidad. La novedad en el número de Colaboradores que han dado positivo al test del coronavirus, viene marcada por los datos indicados en América Latina. En el resto del mundo donde está presente la Orden, en estos últimos meses los contagios han decrecido bastante, aunque siempre se han dado algunos nuevos casos. En el conjunto, desde el inicio, se han contagiado en torno a 1.500 Colaboradores de los cuales tres fallecieron. El número de personas contagiadas por coronavirus que 


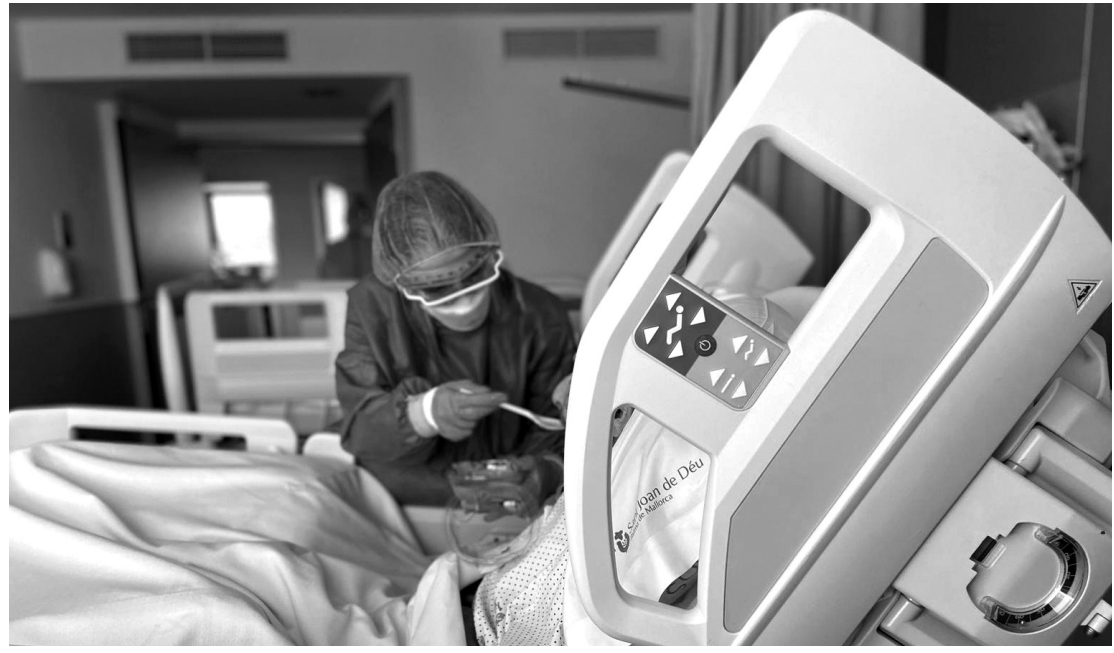

han ingresado en nuestros hospitales y aquellas que han sido positivas al virus en nuestros centros residenciales y sociales son alrededor de 6.000 pacientes, de los que en torno a 550 han fallecido. Pidamos al Señor por los miembros de nuestra Familia Hospitalaria afectados por la Covid-19, por todos los pacientes de nuestros Centros y por todas las personas que en todo el mundo están sufriendo los efectos de la pandemia y por aquellos que han fallecido. Descrita la situación en Superior General recomienda afrontarla al estilo de San Juan de Dios: A todos los responsables, Hermanos y Colaboradores, se agradece el esfuerzo y el compromiso por mantener viva la misión y el servicio a los enfermos en cada uno de los Centros. Agradecimiento también a todos los Hermanos y Colaboradores, por el enorme empeño y dedicación en estos tiempos difíciles de la pandemia. En particular reconocimiento a los Centros de acción social, ancianos, residencias, centros de salud mental y de discapacitados por el gran servicio que están haciendo en el cuidado de las personas asistidas y sus familias. A nivel interno de la Orden y de las Provincias los efectos de la pandemia están influyendo de manera importante en la dinámica y en los programas previstos. La movilidad sigue siendo muy reducida y ello nos está llevando a tener que realizar muchas actividades y reuniones a nivel virtual. Las Provincias y las Regiones están siguiendo, en la medida de sus posibilidades, encuentros y reuniones de forma telemática. Mientras se concluye con unas breves palabras del Papa Francisco en la Audiencia General del pasado 9 de septiembre, en la que hizo su sexta catequesis 
sobre la pandemia, titulada "Curar el mundo. Amor y bien común". Un virus que no conoce barreras, fronteras o distinciones culturales y políticas debe ser afrontado con un amor sin barreras, fronteras o distinciones. Este amor puede generar estructuras sociales que nos animen a compartir más que a competir, que nos permitan incluir a los más vulnerables y no descartarlos, y que nos ayuden a expresar lo mejor de nuestra naturaleza humana y no lo peor. El verdadero amor no conoce la cultura del descarte, no sabe qué es. De hecho, cuando amamos y generamos creatividad, cuando generamos confianza y solidaridad, es ahí que emergen iniciativas concretas por el bien común. Y esto vale tanto a nivel de las pequeñas y grandes comunidades, como a nivel internacional. Lo que se hace en familia, lo que se hace en el barrio, lo que se hace en el pueblo, lo que se hace en la gran ciudad e internacionalmente es lo mismo: es la misma semilla que crece y da fruto. Si tú en familia, en el barrio empiezas con la envidia, con la lucha, al final habrá la" guerra". Sin embargo, si tú empiezas con el amor, a compartir el amor, el perdón, entonces habrá amor y perdón para todos. En este tiempo de pandemia, dejemos de competir y rompamos las fronteras que nos separan y sigamos proponiendo la cultura de la hospitalidad y de la fraternidad, que genera solidaridad y bien común, que no descarta a nadie y cuida con especial ternura y amor a los más pobres y vulnerables.

Roma, 13 de noviembre de 2020: Nos acercamos al tercer sábado de noviembre, solemnidad del Patrocinio de Santa María Virgen sobre nuestra Orden, Reina de la Hospitalidad y Patrona de la Familia de San Juan de Dios. Este año será el día 21 y con tal motivo os envío a todos mi cordial felicitación y mis mejores deseos para que la preparéis y la celebréis con devoción y alegría. Este año todo viene mediatizado por la pandemia del coronavirus que está afectando con fuerza a todo el mundo y por tanto a nuestra Orden, con diferentes grados de intensidad y según los periodos del año. Casi 50 millones de personas se han contagiado hasta la fecha y en torno a 1,3 millones han fallecido desgraciadamente. En la actualidad y cuando parece que en algunos lugares comienzan a descender un poco los contagios y fallecimientos, como es el caso de algunos países de América Latina y Asia, en otros países hemos entrado de lleno en lo que llaman la segunda ola de contagios, los cuales han aumentado y están volviendo a crear dificultades a nivel sanitario, económico y 
social. Es el caso de toda Europa especialmente. En cuanto al continente africano las cosas siguen más atenuadas hasta el momento, pero con mucha vigilancia ya que algunos contagios y fallecimientos también se están dando. En cuanto a la Orden la afectación de la pandemia está en relación a la situación que se vive en cada continente y país. En total y desde el inicio de la misma 82 hermanos (incluidos 6 aspirantes) se han contagiado y 7 han fallecido a causa de la Covid-19. Actualmente son 9 hermanos contagiados, todos ellos están bien por el momento. Los Colaboradores infectados han disminuido, pero con la llegada de la segunda ola, vuelven a crecer los contagios y los aislamientos, lo cual está provocando problemas serios de personal en muchos de nuestros Centros. Sin embargo, el número de fallecidos no ha aumentado y se mantiene en tres, que se produjeron en los primeros meses de la pandemia. Las dificultades sanitarias, económicas y sociales continúan creciendo cada vez más, así como aquellas que afectan a la salud mental, la ética y la vida espiritual y religiosa de las personas y de la sociedad en general. En espera de la llegada de una vacuna eficaz y segura, no se ve claro el final de la pandemia y el hecho de llegar nuevas olas de contagios está ahondando todas estas problemáticas y otras nuevas. Una problemática que me parece muy importante es la soledad en la que muchas personas viven estos momentos, especialmente los enfermos que en los hospitales pasan su proceso de enfermedad e incluso fallecen sin la compañía de sus familiares y amigos. También las personas solas en la vida, sin hogar, ancianos/as que viven en soledad, con el miedo y la incertidumbre de ser olvidados. Todos ellos necesitan una mano samaritana y llena de hospitalidad, que les haga sentir el calor de la humanidad y el amor que sale del corazón. Hermanos y Colaboradores, jno olvidemos a las personas en soledad que viven en nuestros Centros! Como San Juan de Dios, veamos en ellos la presencia del mismo Dios, que a todos nos ama y jamás nos abandona. No olvidemos tampoco a los Hermanos enfermos y ancianos que sufren especialmente en este tiempo la soledad, la ansiedad y la incertidumbre. A todos y en especial a los Hermanos os pido que estéis con ellos y les ayudéis a pasar esta difícil situación. ¡No olvidemos la hospitalidad con los que sufren en soledad!

Descrita la situación en Superior General recomienda afrontarla al estilo de San Juan de Dios: En estas circunstancias somos llamados a vivir este año la solemnidad de Nuestra Madre y Patrona. Ella, la siempre entera, fue la Madre que acompañó, amó y sostuvo 
permanentemente a san Juan de Dios a lo largo de su vida y también en los momentos de enfermedad y en su agonía. Ella ha sido y sigue siendo quien acompaña y patrocina la misión de hospitalidad de la Orden, es quien desde el silencio nos enseña a descubrir la presencia de su Hijo en nosotros y en nuestros Hermanos más necesitados. ¡Cuántas bellas experiencias de Nuestra Madre del Patrocinio han vivido los Hermanos a lo largo de nuestra historia y en la actualidad! En este tiempo de pandemia Nuestra Madre, laVirgen del Patrocinio, nos impulsa a vivir dos advocaciones suyas muy universales en la Iglesia y muy necesarias actualmente. Por una parte, la esperanza. ¡Madre de la Esperanza! [...] Por otra parte con frecuencia invocamos a María como "Salud de los enfermos". Nos pide que seamos prójimos de todos ellos, como el buen samaritano, como San Juan de Dios. Nos pide que seamos creativos y capaces de innovar en la hospitalidad, para cuidar y curar a nuestros Hermanos que sufren. $Y$ la enfermedad continuará entre nosotros.

Una vez más, apreciamos en las cartas circulares del Superior General un estilo concreto en la manera de afrontar la acción de la Orden Hospitalaria. El posicionamiento que establece frente a una crisis producida en nuestra sociedad por un elemento externo, nos actualiza el modo de hacer de Juan de Dios. La manera de actuar siguiendo la tradición y cultura carismática de la Orden. El enfermo se sitúa en el centro de todo el interés, donde la disponibilidad de los Hermanos y sus colaboradores es absoluta, "aún a riesgo de la propia vida". Poniendo en valor el cuidado de los aspectos corporales, pero atendiendo de manera expresa a la dimensión religiosa y espiritual de cada uno de los individuos enfermos, o más vulnerables.

\section{BIBLIOGRAFÍA}

BENAVIDESVÁZQUEZ, Francisco. La epidemia de cólera morbo de 1885 y la heroica actuación de la Orden Hospitalaria. En: Revista San Juan de Dios. Noviembre-diciembre 2020, nº 610, pp. 10-11.

BENAVIDESVÁZQUEZ, Francisco y LÓPEZ-ÁVILA, Ma Begoña. La aportación terapéutica y asistencial de la Orden Hospitalaria frente a la epidemia de cólera morbo en 1885 en España. Colección epistolar. En: Archivo Hospitalario. Revista de Historia de la Orden Hospitalaria de San Juan de Dios. Granada: Archivo-Museo San Juan de Dios"Casa de los Pisa", 2020, n 18, pp. 19-61. 
CASTRO, Francisco de. Historia de la vida y sanctas obras de Iuan de Dios... Granada: Antonio de Librixa, 1585.

CELI. Dionisio de. Miraculosa vida y santas obras del Beato Patriarca Juan de Dios [...] Burgos, 1621.

Carta de Identidad de la Orden Hospitalaria de San Juan de Dios: La asistencia a los enfermos y necesitados según el estilo de San Juan de Dios. Granada: Archivo - Museo San Juan de Dios, 2019

CERVERA, Manuel. Cinco españoles olvidados que cambiaron el mundo luchando contra epidemias y salvado miles de vidas. En: ABC. 16 marzo 2020.

ESEVERRI CHAVERRI, Cecilio. Historia de la enfermería española e hispanoamericana. Barcelona: Salvat editores, S.A. Biblioteca de enfermería, 1984.

GARCÍA BLANCO, Miguel, O.H. Cartas de San Juan de Dios. Texto original y transcripción moderna. Roma, 1987.

GARCÍA RÍOS, José María. San Juan de Dios en España (19502020). Una respuesta desde la hospitalidad. Granada: ArchivoMuseo San Juan de Dios"Casa de los Pisa", 2021. Colección Temas Históricos O.H.

GIL ROLDÁN, Carlos. O.H. Glorias de los Hijos de San Juan de Dios N.P. de la Congregación de España. Noticias históricas de los servicios que a Dios y al Rey han hecho desde su fundación en tiempo de calamidades públicas, de guerra y peste. Madrid: Tipografía de la viuda de Ibarra, 1796.

GÓMEZ BUENO, Juan Ciudad, O.H. Historia de la Orden Hospitalaria de San Juan de Dios. Granada: Archivo - Museo San Juan de Dios"Casa de los Pisa", 1963.

GÓMEZ BUENO, Juan Ciudad, O.H. El resurgir de una obra. Granada: Archivo - Museo San Juan de Dios"Casa de los Pisa", 1950

CIUDAD GÓMEZ, Juan, O.H. Necrologio de la Orden Hospitalaria. Actualizado por MUÑOZ MARTÍNEZ, José Luis, O.H. Granada: Archivo-Museo San Juan de Dios"Casa de los Pisa", 2021.

JAVIERRE, José María. Juan de Dios loco en Granada. Salamanca: Ediciones Sígueme, 1996

LABORDE VALVERDÚ, Agustín. El enfermero de Dios. Granada: Diputación Provincial, 1972.

LIZASO BERRUETE, Félix, O.H. Perfil juandediano del Beato Benito Menni (463 cartas). Granda: 1985. 
MAGLIOZZI PIRRO, José. La conversión de San Juan de Dios fue sin duda en 1538. En: El granado, apuntes virtuales juandedianos. 20 de enero de 2016, año II, $n^{\circ} 1$.

MARTÍNEZ GIL, José Luis, O.H. Proceso de beatificación de San Juan de Dios. Madrid: B.A.C., 2006.

MASCAREÑAS, Gerónimo. Vida, virtudes y maravillas del Beato Juan Grande de la Orden Hospitalaria de San Juan de Dios. Madrid: Imp. del asilo de huérfanos del S. C. de Jesús, 1929.

PLUMED MORENO, Calixto. Las epidemias y enfermedades, siempre han estado presentes. En: Archivo Hospitalario. Revista de Historia de la Orden Hospitalaria de San Juan de Dios. Granada: Archivo - Museo San Juan de Dios"Casa de losPisa", 2020, n 18, pp. 77-165.

POZO, Luciano del, O.H. Vida de San Juan de Dios. Madrid: Imprenta del Asilo de Huérfanos del S.C. de Jesús, 1913.

Primitivas Constituciones de la Orden Hospitalaria. Granada: En casa de Hugo de Mena; 1585. Edición facsímil: Madrid: Orden Hospitalaria. Provincia Castilla, 1977.

PUNTONI, Victoriano. Trattato d'igiene. Tomo II. Roma, 1948.

REPETTO BETES, José Luis. Jerez tiene un Santo. Jerez de la Frontera: Unión de cofradías de Jerez. Caja San Fernando, 1997.

REVUELTA GONZÁLEZ, Manuel. La exclaustración (1833-1840). Madrid: BAC, 1976.

RIESCO ÁLVAREZ, Valentín A., O.H. Seguir y servir a Cristo en Hospitalidad. Constituciones de la Orden Hospitalaria de San Juan de Dios. Madrid: Fundación San Juan de Dios, 2019.

RUSSOTO, Gabriel. MUÑOZ MARTÍNEZ, José Luis O.H. (trad.). San Juan de Dios y su Orden Hospitalaria. Segundo volumen. Granada: Archivo-Museo San Juan de Dios"Casa de los Pisa", 2012. Colección Temas Históricos O.H.

SÁNCHEZ MARTÍNEZ, José, O.H. Kénosis-Diakonía en el itinerario espiritual de Juan de Dios. Madrid: Fundación Juan Ciudad, 1992.

SÁNCHEZ MARTÍNEZ, José, O.H. Fundación de la Orden Hospitalaria. 1.- San Juan de Dios fundador y su fundación. Granada: Archivo - Museo San Juan de Dios"Casa de los Pisa", 2012. Colección Temas Históricos O.H.

SANTOS, Juan, O.H. Chronología Hospitalaria y resumen historial de la Sagrada religión del Glorioso Patriarca San Juan de Dios. Madrid, 1715.

SOLANA BERMEJO, Asier. Cristianos y peste: morir y vivir. En:

Eclessia. Abril 2020, n 2028. 


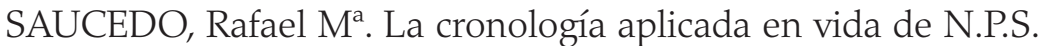
Juan de Dios. En: Paz y Caridad. Enero-febrero 1952, n 13.

VALERO HURTADO, Luis. O.H. El P. Giovanni Maria Alfieri y la reforma de la Orden Hospitalaria de San Juan de Dios en el siglo XIX. 1862-1888. La santidad en tiempos de crisis. Granada: ArchivoMuseo San Juan de Dios "Casa de los Pisa", 2014. Colección Temas Históricos O.H.

VENTOSA ESQUINALDO, Francisco, O.H. Pensamiento de San Juan de Dios y la Orden Hospitalaria y su relación con la enfermería: conceptos y valores. Granada: Archivo-Museo San Juan de Dios"Casa de los Pisa", 2012. Colección Temas Históricos O.H.

ZAMORA BERMÚDEZ, Manuel. Estructura benéfico-sanitaria en la Málaga de fines del siglo XVII. Hospitales de San Julian y San Juan de Dios. Málaga: Universidad de Málaga. Exma. Diputación Provincial de Málaga, 1987.

\section{APENDICE DOCUMENTAL}

\section{[Anexo $1 \cdot$ Documentos agradecimiento asistencia cólera]}

9 de septiembre de 1885 - Teruel

Nos el doctor don Antonio Ibáñez y Galiano, por la gracia de Dios y de la Sta. Sede Apostólica, Obispo de Teruel y Administrador Apostólico de la Diócesis de Albarracín; Prelado Doméstico de Su Santidad, Asistente al Sacro Solio Pontificio y Noble Romano, Caballero Comendador de la Real y distinguida Orden de Carlos III, y Caballero Capellán Maestrante de la Real de Valencia, etc., etc. Hay un sello. Consignamos en las presentes con gran gusto y complacencia suma: Que los Hermanos Hospitalarios de S. Juan de Dios, residentes en Ciempozuelos, han cumplido como buenos hijos de tan gran Santo, en estas nuestras Diócesis de Teruel y Albarracín, con lo que su instituto les manda, durante la epidemia que tantas víctimas ha causado en aquellas. Han recorrido muchos pueblos y también esta Capital, y han sabido, con la ayuda de Dios, librar de una muerte casi segura, a muchos infelices con los medios, que sus conocimientos en la muy grave enfermedad del Cólera les proporcionan. Han asistido a los enfermos con una caridad heroica, infundiendo valor a los pusilánimes, alentando a los débiles, excitando al dolor de sus 
culpas a los moribundos, y haciendo conocer a todos lo que valen los Religiosos en las grandes angustias y pruebas por que atraviesan las sociedades. Dios Nuestro Señor, rico en misericordias, premia tanto celo, abnegación tanta, y caridad tan ardiente. Nos, con nuestros Diocesanos, agradecemos al Todopoderoso tan grande misericordia como ha tenido con nosotros, dándonos con dichos Hermanos consuelo en nuestra aflicción, aumento de gracias con sus oraciones, y el haber edificado a los fieles con su conducta ejemplarísima y relevantes virtudes. Consignamos, finalmente, que la grata memoria que dejan en esta tierra Aragonesa será perdurable. Nos, al despedirnos con lágrimas en los ojos, pedimos a Dios desde lo último de nuestro corazón les bendiga, haga prosperar en España tan caritativo instituto, y, si es posible, lo veamos en nuestra Diócesis, y con grande agradecimiento les damos la bendición más entusiasta y cariñosa, en el nombre del Padre y del Hijo y del Espíritu Santo. Amén. Teruel, 9 de septiembre de 1885. Antonio, Obispo de Teruel. Administrador Apostólico de Albrr. Rubricado.

8 de octubre de 1885 -Yunquera (Málaga)

Don Adolfo Gómez Guerrero, Alcalde Constitucional de esta Villa Certifico: que invadida esta población por el Cólera Morbo, y cuando más estragos hacía la epidemia, se presentaron el diez y siete del próximo pasado mes de septiembre dos hermanos de la orden Hospitalaria de San Juan de Dios llamados Tomás de Aquino y Casimiro López, los cuales desde el acto mismo de su llegada y sin darse un momento de reposo, se dedicaron a visitar enfermos, proporcionándoles, gracias a su inagotable caridad y sublime abnegación, todo género de cuidados y auxilios; con lo cual alentaban el abatido espíritu de los pacientes que al verlos a la cabecera de sus lechos, los consideraban como Ángeles tutelares, y hasta les hacían más llevadero y apacible el terrible trance de la muerte; dando por resultado tanto heroísmo y virtud, el que el referido hermano Casimiro López, fuese atacado por el virus colérico y fallecido a la una de la tarde del veinte y cinco del referido septiembre con la resignación de un justo, y en medio de las lágrimas que copiosamente derramaban cuantas personas tuvieron la noticia del desgraciado suceso. Así mismo certifico: que al poco tiempo de ocurrir el mencionado fallecimiento llegaron a la población otros dos Hermanos de la misma referida Orden, llamados Rafael Mateos y Bernardino, procedente el primero 
de Málaga y el segundo de Ciempozuelos, los cuales asociados al susodicho Hermano Tomás de Aquino, prosiguieron su humanitaria y santa obra con la misma energía de que queda hecho mérito, hasta que extinguida la epidemia, se retiraron a sus respectivas casas, llevándose consigo la admiración y cariño de todo este vecindario, que con lágrimas en los ojos y profundo enternecimiento en el corazón, salió en masa a despedirlos, demostrándole profundo agradecimiento de gratitud que embargaba el ánimo de todos los imperecederos recuerdos de grandeza de alma e inagotable caridad que en pos de sí dejaban.Y para que conste y surta los debidos efectos, firmo y sello el presente en Yunquera ocho de octubre de mil ochocientos ochenta y cinco $=$ El Alcalde. Adolfo Gómez. Rubricado. Hay un sello.

1907 - Zaragoza Rvdo. Padre Luciano: Recibí su grata con inmensa complacencia al ver se encuentra bien, de los datos que me pide respecto a la epidemia del año 85 procurare darle una relación detallada. Con objeto de prestar su asistencia a los coléricos de Aranjuez recibió el Superior de Granada orden de trasladarse a la antedicha población pero habiendo llegado y encontrándose solo a consecuencia de haber partido los Hnos. que habían de formar la brigada que se disponía a prestar en el dicho Aranjuez sus servicios hospitalarios hubo de regresar a Granada llevando a prevención un bote de extracto-tebaico. Por llegar de una parte de la Península donde a la sazón era más terrible el estrago de la peste vióse precisado a detenerse por espacio de cuatro días en el lazareto de Granada. Después llegó al Hospital de la Orden y púsose de acuerdo con el Médico del establecimiento para sí se presentaba algún caso de cólera estar dispuestos a combatirle. No tardó mucho en presentarse el cruel azote pues sería el mes de junio cuando un día se presentó el citado médico D. Manuel deVázquez y participó al superior haber descubierto un caso de cólera siendo de notar que este fue el primero que se registró en Granada. Al momento se trasladaron ambos a la casa del atacado y al dejarla lo hicieron con gran satisfacción por advertirse a la primera inyección que se le puso una notable mejoría. Aquel mismo día con ocasión de hallarse juntos el Superior y el Médico, en casa del último, recibieron la visita de dos Facultativos que iban comisionados por el Ayuntamiento, recriminaron al Médico y Superior del Hospital porque al decir de ellos habían sembrado la alarma en Granada sin motivo fundamentado, siendo en vano todo el trabajo que se tomaron 
para convencerlos que la Capital está invadida de cólera, por fin se dirigieron en el mismo coche que los había llevado a la habitación del enfermo donde los médicos del Ayuntamiento después de un detenido examen afirmaron existir la epidemia en Granada. Dióse al atacado una segunda inyección habiendo a los pocos días vencido por completo la enfermedad. A los quince días era ya un hecho la existencia del cólera atacando con gran violencia a multitud de personas de la Capital y sus inmediaciones, dedicándose enteramente el Superior del Hospital a la asistencia de los coléricos. Algunos días después por padecer el Médico una indisposición hubo el superior de girar la visita hasta su restablecimiento, al visitar una mujer atacada de un cortijo de las afueras (la que murió a pesar de los cuidados que se la prodigaron) le dijeron que en la misma casa acababa de morir una hija de esta de trece meses reconociendo el cadáver de la niña vio que todavía tenía vida y dándola fuertes friegas en las piernas recobró el conocimiento y logró ponerse bien del todo. Como la epidemia tomaba cada vez más proporción se estableció la asistencia facultativa por distritos, poniendo un médico por cada parroquia al cuidado de los coléricos, luego que el servicio se regularizó el Superior del Hospital se retiró a este pero tuvo que abandonarle días después para atender a una anciana que pedía ser asistida por los Hnos. habiendo sido inútil todos los cuidados pues por fin murió después de recibir los Santos Óleos.Y aun cuando había hecho propósito el Superior de no dejar el Hospital tuvo que salir de nuevo por avisarle que en una casa de las cercanías una niña se moría sin tener nadie que la asistiera, estándola cuidándola aunque sin esperanza dada su gravedad se presentó el padre de la niña con síntomas del cólera. Cuando llegó la Extremaunción que habían avisado para la niña ya era tarde por haber dejado de existir si bien pudo administrarle al padre que falleció poco después. Por entonces D. Benito Hernando Catedrático de la Facultad solicitó del Superior, personal para la asistencia de los enfermos en un Hospital de coléricos que se había establecido en Granada, al que se le facilitaron tres Religiosos, yendo al frente de ellos Fr. Ignacio Estruch, los que cumplieron su misión hospitalaria hasta el fin de la epidemia. Instalóse la Casa de los Pisas como enfermería de los Religiosos a la cual fueron trasladados dos de éstos que habían contraído la enfermedad, uno de ellos Fr. Francisco de Gordoa murió, asistiéndolos el Superior el cual contrajo la misma enfermedad días antes de la Asunción y le duró la convalecencia hasta que se extinguió el cólera. 
No obstante tratar la Diputación de gratificar los Hnos. por los servicios prestados durante la epidemia, el Superior renunció a ello contestando a dicha Corporación que al asistir a los coléricos lo hicieron por amor de Dios sin aspirar a ningún premio temporal, que se querían hacer alguna limosna podían hacerla a nuestro Hospital pero no como precio por los cuidados prestados a los enfermos. Reciba, pues, estas indicaciones que más adelante procurare mandarle algún detalle de la fundación. Al mismo tiempo le desea paz en el Señor, rogándole de mis recuerdos al Superior y demás Comunidad, muy especialmente a los Hnos, que hicieron conmigo el Neo-profesorado su humilde Hno. en Cristo. Zaragoza 4 (“) 1907 Hno. Joaquim Estruch. Rubricado

\section{[Anexo 2 - folleto para divulgar la fórmula contra el cólera morbo]}
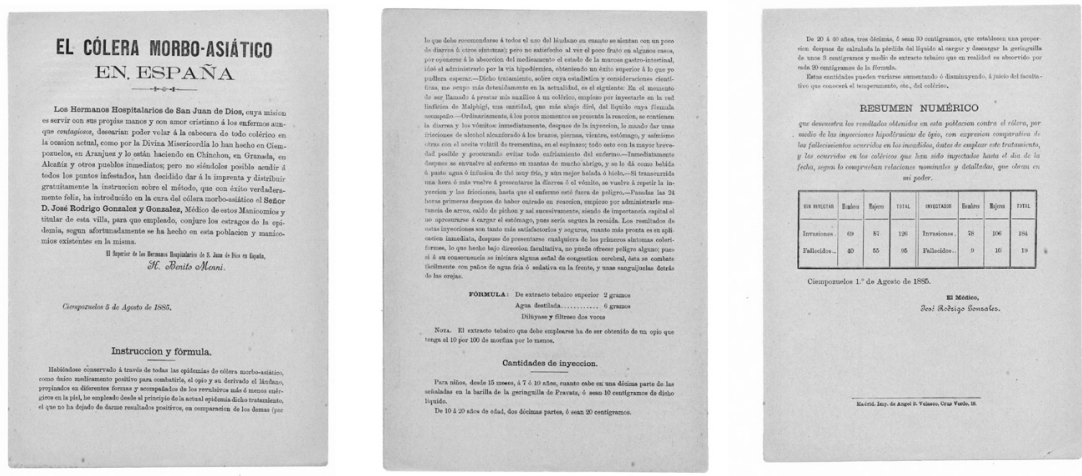

\section{[Anexo 3 - Elogio de Fernando Ónega al Hermano Manuel García ViejoO.H.]}

Locutor (Carlos Alsina): Fernando Ónega, buenas noches

Fernando Ónega: Muy buenas noches Alsina, quiero enviar esta carta a la última víctima española del ébola, a don Manuel García Viejo, un hombre que un día salió de su pueblo de León, no sé si como médico, no sé si como misionero, tampoco sé cuál era el orden de sus vocaciones, médico de almas y médico de cuerpos en todo caso.

Solo sé don Manuel que hay una especie de personas que no parecen de este mundo, son ustedes los cooperantes que se marchan a extraños países a ayudar a gentes que no conocen, son ustedes los médicos que cambian una plácida vida en países de bienestar por 
un trabajo anónimo en países de riesgo, son ustedes los maestros y maestras que quieren alfabetizar el mundo, y son ustedes los misiones que van a predicar la palabra de Cristo. Y para ello abandonan familias y comunidades, y se enfrentan a secuestros y guerras y ahora se enfrentan a ese enemigo despiadado que se llama ébola, y caen en sus garras como cayó usted don Manuel García Viejo.

Y hay algo que me impresionó más que su enfermedad, su deseo de volver a Sierra Leona en caso de que pudiese ser curado.

Hizo de aquellas gentes su familia, hizo su hogar de aquellos lugares castigados por el hambre, mortificados por la sed y la falta de medicinas, pobres de toda pobreza, enfermos que las familias ocultan, pasto de cualquier epidemia que se pueda presentar.

Ustedes son el hospital que muchas veces se reduce a sus brazos y usted, don Manuel, será por mucho tiempo el ejemplo de todos esos servidores públicos que solo como héroes puedo calificar.

Yo quiero coger su nombre y mostrarlo a las generaciones futuras para decirles que no todo ha sido sucio en este tiempo, que hubo y hay gentes como usted que pasaron por este mundo haciendo solo el bien, que arriesgaron sus vidas por salvar otras vidas, que fueron generosos, que fueron sencillamente buenos, por eso me preocupo de ensalzarlo y le pido perdón médico misionero, le estoy llamando don Manuel y creo que debería llamarle san Manuel.

La brújula: Onda Cero

22 de septiembre de 2014 


\section{[Anexo 4 - Carta circular del Hermano Superior Provincial de la Bética, José Antonio Soria Craus]}

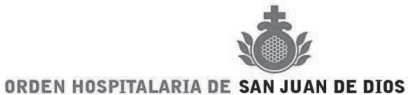

ORDEN HOSPITALARIA DE SAN JUAN DE DIOS

\author{
CURIA PROVINCIAL BÉTICA

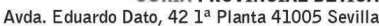 \\ Tfno.: 954933870 \\ Correo: secretaria.provincial@sjd.es
}

Sevilla, 13 de agosto de 2014

\section{A LOS HERMANOS Y GERENTES DE LA PROVINCIA.}

\section{Estimados Hermanos y Colaboradores:}

Cuando todos nos disponíamos a comenzar nuestras vacaciones o estábamos disfrutando de ellas con nuestras familias y amigos, fuimos recibiendo noticias de la situación de nuestros hermanos, hermanas y colaboradores de los Hospitales de San Juan de Dios en Sierra Leona, y especialmente dramáticas noticias de nuestro Hospital en Monrovia (Liberia).

En estos días la Orden Hospitalaria de San Juan de Dios ha estado muy presente en los Medios de Comunicación, debido al contagio y posterior fallecimiento de los tres Hermanos que formaban la comunidad de nuestro Hospital San José de Monrovia, los Hermanos Miguel, Patrick y George, y también la Hermana Chantal, Misionera de la Inmaculada Concepción. Otras dos hermanas, que también trabajaban en el Hospital han dado resultado positivo al test del Ébola y en estos momentos se encuentran convalecientes.

No solo los hermanos y hermanas se han contagiado tratando y cuidando a los enfermos de Ébola, algunos de los colaboradores (médicos, enfermeras, trabajadora social, auxiliares de enfermería, técnicos de laboratorio, etc...) de nuestro Hospital se han infectado y han fallecido. Y cada día sigue muriendo mucha gente anónima que no son noticia en los medios de comunicación social.

Personalmente, he vivido en Monrovia y he trabajado en ese Hospital durante 14 años, conocía a todos los hermanos y hermanas, compartiendo con algunos de ellos trabajo, ilusiones, oración y sufrimientos durante los años de guerra civil que asoló el país. Me llegan noticias del fallecimiento de trabajadores del Hospital a los que conocía, muertes a las que pongo cara, nombres e historias personales y familiares compartidas.

La historia de la Orden Hospitalaria a lo largo de los siglos está llena de nombres de Hermanos que han dado su vida atendiendo a los enfermos en las epidemias, pestes, guerras y catástrofes. Hoy a esa cadena de la historia de la Hospitalidad se suman nuestros hermanos y colaboradores de Monrovia, los cuales con sus vidas nos han demostrado que Juan de Dios sigue vivo. Un verdadero testimonio para cada uno de nosotros de entrega, solidaridad, compromiso y dedicación hasta el final.

Todos conocemos, a través de la enorme difusión en los distintos medios de comunicación, las consecuencias que la epidemia del Ébola está teniendo en la población de los países afectados, ya de por si faltos de recursos sanitarios para cuidar a los enfermos y proteger a los profesionales de la salud. Colegios, universidad, ministerios, tiendas, Hospitales y Centros de Salud cerrados, salida del país de muchos profesionales sanitarios, y un largo etcétera que hace que se esté viviendo una situación caótica de miedo, incertidumbre y muerte. 


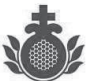

La Epidemia no está controlada todavía, pero no nos podemos rendir ante el Ébola. La Orden Hospitalaria, a través de la Fundación Juan Ciudad ONGD, está tratando de organizar un equipo de hermanos y colaboradores sanitarios, que con medidas de protección y recursos suficientes pueda desplazarse a Liberia para reabrir el Hospital y atender a los enfermos. Personas a las que no les importa poner en peligro sus vidas para ayudar a los pobres y necesitados.

Confiamos en que tras la muerte de nuestros hermanos, hermana y colaboradores, nuestro esfuerzo se dirija y vuelque en ayudar a los países que están sufriendo esta epidemia, y como Familia Hospitalaria colaboremos con los recursos necesarios para ayudar a nuestro Hospital de Sierra Leona a mantenerse abierto, y que el Hospital de Monrovia pueda reabrir sus puertas en estos momentos de tanta necesidad.

Vivimos en una situación de crisis, donde muchas personas y familias lo están pasando muy mal, pero hagamos un pequeño esfuerzo por aquellos hermanos nuestros que viven en una situación de crisis permanente. Todos podemos colaborar: hermanos, trabajadores, voluntarios, bienhechores, cada uno de los Centros y Comunidades... Concienciémonos y movilicémonos en la medida que podamos, a todo nuestro entorno para obtener recursos económicos y materiales a fin de ayudar a los pacientes que sufren por esta epidemia.

Este será el mejor homenaje a estos hermanos y hermanas nuestros que dieron su vida en la Misión.

Confiando en la generosidad de cada uno de vosotros, que San Juan de Dios y San Juan Grande, el cual murió como consecuencia de una epidemia en Jerez, sean nuestros modelos de entrega sin límites y sin condiciones en nuestra Misión de Hospitalidad, con un corazón sin fronteras.

Tenemos presente en nuestras oraciones a todos nuestros hermanos y hermanas fallecidos como consecuencia de esta epidemia, y también a sus familiares en estos momentos de dolor.

Que el Dios de la Vida plena nos de la fortaleza y esperanza en un mundo más justo y solidario.

Fraternalmente.

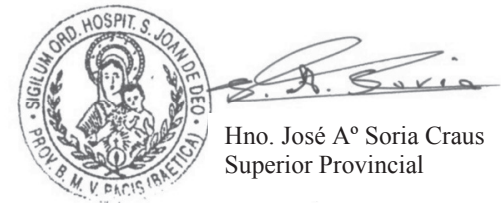

